\title{
NOBLEZA Y SEÑORÍOS EN CASTILLA LA VIEJA MERIDIONAL A MEDIADOS DEL SIGLO XIV*
}

\author{
Ignacio Álvarez Borge**
}

\section{INTRODUCCIÓN}

Cuando Pedro I accedió al gobierno efectivo de su reino de Castilla, tras recuperarse de la enfermedad -seguramente la peste- que le mantuvo alejado de la toma de decisiones en los primeros meses de su reinado, su privado Juan Alfonso de Alburquerque solicitó en las Cortes de Valladolid de 1351 que las villas de behetría fueran repartidas entre quienes eran sus naturales como si fueran solariegos. Al reparto se opuso un poderoso señor de behetrías como era Juan Rodríguez de Sandoval. Pero el rey ordenó que se realizara una pesquisa general en la Merindad Mayor o Adelantamiento de Castilla para conocer la situación de las behetrías. Es un episodio bien conocido que fue narrado por el canciller Pedro López de Ayala cuando escribió la Crónica de Pedro $I$. El resultado de la pesquisa es el libro conocido como Becerro de las Bebetrías $^{2}$. En el Becerro se registraron, entre otras cosas, la situación señorial y el nombre

* Este artículo ha sido realizado con el apoyo de una Ayuda a la Investigación de la Universidad de La Rioja.

** Universidad de La Rioja

1. Crónica de Pedro I en C. ROSSELL (ed. ), Crónicas de los Reyes de Castilla, vol. I, en Biblioteca de Autores Españoles, T. 66, Madrid, 1953, pp. 417-418; J. L. MARTÍN (ed. ), Pedro López de Ayala. Crónicas, Madrid, 1991, pp. 38-42; C. ESTEPA, "Las behetrías en el canciller don Pedro López de Ayala, en M. I. LORING (ed), Historia social, pensamiento bistoriográfico y Edad Media. Homenaje al Profesor Abilio Barbero, Madrid, 1997, pp. 95-114. Sobre el reinado de Pedro I, L. V. DÍAZ MARTÍN, Itinerario de Pedro I. Estudio y regesta, Valladolid, 1975; L. V. DÍAZ MARTÍN, Pedro I (1350-1369), Palencia, 1995; C. ESTOW, Pedro I the Cruel of Castile, Leiden, 1995; y P. GARCÍA TORAÑO, El rey don Pedro el Cruel y su mundo, Madrid, 1996. Sobre el contexto sociopolítico de esos momentos, L. V. DÍAZ MARTíN, Los oficiales de Pedro I de Castilla, Valladolid, 1987; S. de MOXO, "De la nobleza vieja a la nobleza nueva. La transformación nobiliaria castellana en la Baja Edad Media", en Cuadernos de Historia. Anexos de la revista Hispania, 3 (1969), pp. 1-210; y S. de MOXO, "La sociedad política castellana en la época de Alfonso XI", en Cuadernos de Historia. Anexos de la revista Hispania, 6 (1975), pp. 187-326.

2. Editado por G. MARTÍNEZ DÍEZ, Libro Becerro de las Bebetrías. Estudio y texto crítico, León, 1981. En adelante citaré Becerro y cuando haga referencia a la información en él contenida añadiré el número de merindad en números romanos y el del lugar o lugares de referencia en arábigos. 
del señor o señores de todos -o casi todos- los lugares que formaban unidades fiscales dentro de 15 de las merindades menores que se integraban en la Merindad Mayor de Castilla.

A partir de la información proporcionada por el Becerro, en un reciente artículo he analizado la estructura señorial existente a mediados del siglo XIV en una amplia zona de Castilla la Vieja, comprendida en las merindades de Cerrato, Villadiego, Castrojeriz, Muñó, Burgos con Ubierna y Silos ${ }^{3}$.Ahora me propongo avanzar en el análisis, estudiando quiénes eran los señores que podían ejercer derechos señoriales en esa zona, tomando como base igualmente la información que proporciona el Becerro. Con ello pretendo también reflexionar sobre la organización interna de la nobleza a mediados del siglo XIV y los distintos criterios disponibles para establecer los perfiles de algunos de sus grupos o fragmentos de clase.

En conjunto, el área que he estudiado abarca más de $11.000 \mathrm{kms}^{2}$. Dentro de las seis merindades menores consideradas es posible obtener información sobre la situación señorial de 684 lugares, a partir de los 630 epígrafes incluidos en el Becerro ${ }^{4}$. Esos 684 lugares se distribuyen de la siguiente forma: 111 en la merindad de Cerrato (en 93 epígrafes), 104 en Villadiego (en otros tantos epígrafes), 121 en Castrojeriz (114 epígrafes), 79 en Muñó ( 73 epígrafes), 121 en Burgos (117 epígrafes) y 148 en Silos (129 epígrafes). De acuerdo con su situación señorial, los 684 lugares se concretan en 261 behetrías, 203 abadengos, 112 solariegos, 40 realengos, 3 lugares cuyo señorío se desconoce y 65 condominios de las diversas combinaciones posibles, aunque 49 de ellos son condominios de abadengo y solariego.

De las conclusiones que se pueden extraer del análisis de la estructura señorial de la zona, quisiera tomar ahora dos como puntos de partida. En primer lugar, la mayor importancia del señorío laico sobre el eclesiástico. Sumando las behetrías más los solariegos más los lugares de condominio con cualquier forma de participación de behetría o solariego, obtenemos que los nobles laicos podían ejercer derechos señoriales en un total de 436 lugares; es decir, el $6374 \%$ de los 684 lugares considerados. Haciendo la operación equivalente con los abadengos más todo tipo de conominios con participación de abadengo, obtenemos la cifra de 265 lugares, el 38'74\%. Como es bien sabido, el volumen de documentación conservada para el periodo anterior a la segunda mitad del siglo XIV no se corresponde en absoluto con estas cifras, puesto que es de procedencia eclesiástica en su gran mayoría. Eso implica que conocemos mucho mejor la historia de los señoríos eclesiásticos que la evolución de los señoríos de la nobleza. Obviamente, unos y otros tuvieron aspectos comunes, pero las características y el funcionamiento de ambos no eran idénticos en absoluto. No podemos reconstruir la historia de los señoríos plenomedievales castellanos atendiendo sólo a lo que cono-

3. I. ÁLVAREZ BORGE, "Señoríos en Castilla la Vieja a mediados del siglo XIV", en prensa.

4. El Becerro no ofrece una lista de lugares o núcleos de poblamiento sin más, sino de aquellos que tenían entidad fiscal y/o jurisdiccional. Así, hay lugares con aldeas dependientes y estas últimas pueden aparecer sólo mencionadas en el epígrafe correspondiente al lugar principal -caso más frecuente- o en su propio epígrafe. Otro problema son los despoblados, algunos de los cuales aparecen y otros no. Por último, un tercer problema son los lugares que no se mencionan sin que aparentemente existan justificaciones, debido a posibles errores de los pesquisidores, etc. Sobre todo ello, I., ÁLVAREZ BORGE, El feudalismo castellano y el libro Becerro de las Bebetrías. La merindad de Burgos, Valladolid, 1987, pp. 5457; y con referencia concreta a las merindades aquí estudiadas I. ÁLVAREZ BORGE, "Señoríos en Castilla...". 
cemos de las instituciones eclesiásticas. Es necesario aumentar el esfuerzo en la investigación sobre los señoríos de la nobleza laicas. En ese sentido, para Castilla la Vieja resulta imprescindible tener en cuenta el señorío de behetría ${ }^{6}$. En la zona que he estudiado había 261 behetrías y otros 13 condominios con participación de behetría; en total, la behetría estaba presente en 274 lugares que suponen el 40 '05\% de los 684 para los que dispongo de información. La behetría es, por lo tanto, la forma señorial más importante en general y en lo que se refiere a los señoríos de la nobleza en particular. Frente a las cifras que acabo de mencionar, el solariego único o compartido estaba presente en 165 lugares, el 24'12\%. Ciertamente, es muy importante tener en cuenta que había diferencias notables en las distintas zonas. Pero, atendiendo sólo a las agrupaciones de lugares por merindades, sin entrar en análisis comarcales o subcomarcales de detalle, se observa que en ninguna merindad la behetría representaba menos del $25 \%$ de los lugares 7 . Por lo tanto, la importancia del señorío nobiliario y, dentro de él, de la behetría es el primer aspecto que quiero resaltar.

5. Algunos estudios de base comarcal intentar paliar esos problemas; véase P. MARTÍNEZ SOPENA, La Tierra de Campos occidental. Poblamiento, poder y comunidad del siglo X al XIII, Valladolid, $1985 ; \mathrm{Y}$ C. REGLERO, Los Señoríos de los Montes de Torozos. De la Repoblación al Becerro de las Bebetrías (siglos $X-X I V$ ), Valladolid, 1993. Los estudios que se centran en el periodo inmediatamente posterior y, sobre todo, en el siglo XV son mucho más abundantes; véase M. C. QUINTANILLA RASO, "Nobleza y señoríos en Castilla durante la Baja Edad Media. Aportaciones de la historiografia reciente", en Anuario de Estudios Medievales, 4 (1984), pp. 613-639; P. LÓPEZ PITA, "Señorios nobiliarios bajomedievales", en Espacio, Tiempo y Forma. Historia Medieval, 4 (1991), pp. 243-284, con bibliografia en pp. 270-284; y J. M. MONSALVO, "Historia de los poderes medievales, del Derecho a la Antropología (el ejemplo castellano: monarquía, concejos y señoríos en los siglos XII-XV)", en C. BARROS (ed.), Historia a debate. Medieval, Santiago de Compostela, 1995, pp. 81-149, con bibliografia en pp. 138-147.

6. Las obras clásicas sobre las behetrías son las de C. SÁNCHEZ ALBORNOZ, "Las behetrías"y "Muchas páginas más sobre las behetrías", ambos en Viejos y nuevos estudios sobre las instituciones medievales españolas, T. I, Madrid, 1976, pp. 17-191 y 195-326 respectivamente; y B, CLAVERO, "Behetría 1255-1365. Crisis de una institución de señorio y de la formación de un derecho regional en Castilla", en Anuario de Historia del Derecbo Español, XLIV (1974), pp. 201-342. Entre las referencias actuales, véase C. ESTEPA, "Formación y consolidación del feudalismo en Castilla y León., en En torno al feudalismo hispánico, Avila, 1989, pp. 157-256; C. ESTEPA, "Estructuras de poder en Castilla (siglos XII-XIII). EI poder señorial en las merindades 'burgalesas", en Burgos en la Plena Edad Media, Burgos, 1994, pp. 245-294; C. ESTEPA, "Propiedad y señorio en Castilla (siglos XIII-XIV)", en E. SARASA y E. SERRANO (eds.), Señorío y Feudalismo en la Península Ibérica (ss. XII-XIX), Zaragoza, 1993, T. I, pp. 373-425; C. ESTEPA, "Las behetrías en el Canciller..."; y C. ESTEPA, Las bebetrías castellanas, en preparación, agradezco al autor haberme permitido consultar diversos capítulos; C. JULAR, "Dominios señoriales y relaciones clientelares en Castilla:Velasco, Porres y Cárcamo (siglos XIII-XIV)" en Hispania, 192 (1996), pp. 137-171; y C. JULAR, "Familia y clientela en dominios de behetría a mediados del siglo XV", en Historia de la familia, 'T. II, Murcia, 1996, pp. 1533; J. ESCALONA, Transformaciones sociales y organización del espacio en el alfoz de Lara en la Alta Edad Media, Tesis Doctoral, Universidad Complutense de Madrid, 1996; J. ESCALONA, "Arcaismos y novedades en el panorama señorial de la región de Salas de los Infantes según el Becerro de las Behetrías", en prensa; I. ÁLVAREZ BORGE, El feudalismo castellano...; I. ÁLVAREZ BORGE, Poder y relaciones sociales en Castilla en la Edad Media. Los territorios entre el Arlanzón y el Duero en los siglos X al XIV, Valladolid, 1996; I. ÁLVAREZ BORGE, "Sobre las relaciones de dependencia en las behetrías castellanas en el siglo XIII: hipótesis a partir del caso de Las Quintanillas", en E. SARASA y E. SERRANO (eds.), Señorío y Feudalismo en la Península Ibérica (ss. XII-XIX), Zaragoza, 1993, T. III, pp. 225-240; I. ÁLVAREZ BORGE, "Lordship and Landownership in the South of Old Castile in the Middle of the Fourteenth Century", en Journal of Medieval History, 23 (1997), pp. 75-88.

7. Para otras zonas los datos serían los siguientes: en la merindad de Castilla Vieja la behetría estaba presente en el $28^{\prime} 03 \%$ de los lugares, en la de Asturias de Santillana en el 59'21\%, en la de Aguilar de Campoo en el 33'58\% y en las merindades de Tierra de Campos en el 18'93\%. Los datos de Castilla Vieja,Asturias de Santillana, y Aguilar de Campoo los proporciona C. ESTEPA en "Estructuras de poder..., pp. 249-250; 
En segundo lugar, otra de las características de la estructura señorial de la zona, que es necesario tener en cuenta, es el elevado grado de fragmentación señorial existente. En parte, es una consecuencia de lo anterior, de la importancia de la behetría, puesto que la behetría, como es sabido, es una forma de señorío en la que varios nobles pueden ejercer derechos señoriales; unos, los naturales o diviseros, ocupan un nivel intermedio mientras que otro es el señor singular o superior del lugar. Por lo tanto, las behetrías por definición tenían más de un señor, en el sentido de que varios nobles podían disponer de derechos señoriales en ellas. La fragmentación señorial se extiende también a los señoríos compartidos; es decir, los lugares en que había varios señores ejerciendo derechos señoriales, bien bajo la misma forma de dominio señorial o bien bajo formas distintas. Por ejemplo, un noble y una institución eclesiástica, como solariego y abadengo, en una situación de condominio típico. Pero también varios nobles como solariego o varias instituciones eclesiásticas como abadengo. En conjunto, había 159 lugares de señorío compartido, lo que representa el 23'24\%, y entre ellos había muy pocas behetrías puesto que, generalmente, en esta zona la behetría aparece poco en condominios y son pocos también los casos en que hay dos o más señores en el nivel de señorío singular. La fragmentación señorial se refiere, por lo tanto, a las behetrías y a los señoríos compartidos y en conjunto se extiende por 396 lugares, que representan el $57,87 \%$ del total ${ }^{8}$. De nuevo, es necesario tener en cuenta que había diferencias en las distintas zonas, pero la cifra casi nunca baja del 50\%, sólo en la merindad de Muñó donde era del 43'03\%. La fragmentación señorial podía llegar a ser muy acusada; 77 de los 159 lugares tenían dos señores pero los restantes 82 tenían más de dos: había 36 lugares con tres señores, 22 con 4,10 con 5,13 con 6 y 1 con 7 .

Señorío nobiliario, behetría y fragmentación señorial son los ejes que quiero destacar de la estructura señorial de la zona.

Existen varios trabajos que se han ocupado de estudiar los señorios que aparecen en el Becerro de las Bebetrias y que han ofrecido recuentos. Diversos estudios sobre dominios eclesiásticos han integrado la información del Becerro con la derivada de otras fuentes . Hay análisis sobre un determinado tipo de señoríos, como el relativo a los de las órdenes militares realizado por S. Moreta ${ }^{10}$. Hay, también, estudios de determinados dominios nobiliarios basados total o parcialmente en el Becerro ${ }^{11}$. Otros tra-

los de Tierra de campos en A.VACA, "La estructura socioeconómica de la Tierra de Campos", en Publicaciones de la Institución Tello Téllez de Meneses, 42 (1979), pp. 203-387.

8. La cifra es el resultado de sumar los 159 señoríos compartidos -que incluyen los 65 condominios y 24 behetrías con más de un señor en el nivel singular- y las 237 behetrías restantes.

9. Por ejemplo, S. MORETA VELAYOS, Rentas monásticas en Castilla. Problemas de método, Salamanca, 1974; y L. MARTÍNEZ GARCÍA, El bospital del Rey de Burgos. Un señorío medieval en la expansión y en la crisis (siglos XIII y XIV), Burgos, 1986.

10. S. MORETA VELAYOS, "Los dominios de la órdenes militares en Castilla según el Becerro de las Behetrías", en Anuario de Estudios Medievales, 11 (1981), pp. 117-138.

11. Entre otros, P. FERNÁNDEZ MARTÍN, "El último señor de las behetrías en Campos", en Hispania, LXXV (1959), pp. 205-229; E. GONZÁLEZ CRESPO,"El patrimonio de los Velasco a través de 'El Libro de las Behetrías'. Contribución al estudio de la fiscalidad señorial", en Anuario de Estudios Medievales, 16 (1986), pp. 239-250; C. JULAR, "Dominios señoriales y clientelas..."; S. R. DOUBLEDAY, The Laras: an Aristocratic Family in the Kingdoms of Castile and León, 1075-1361, Tesis Doctoral, Universidad de Harvard, 1996, pp. 432-461 y Apendix B pp. 494-539, agradezco al autor haberme proporcionado un ejemplar de la reproducción facsímil realizada por la universidad. 
bajos han tomado como ámbito de estudio una zona determinada y analizado los señoríos allí existentes, como hizo A. Vaca para la Tierra de Campos y yo mismo para algunas merindades incluidas también en el ámbito de este trabajo ${ }^{12}$. Por último, E. González Crespo realizó el recuento global más completo de los señoríos nobiliarios en el Becerro disponible hasta ahora ${ }^{13}$. Todos estos trabajos sirven como base al análisis que pretendo realizar, pero los criterios que he seguido son parcialmente diferentes a los utilizados por otros autores. Ello es una consecuencia de los problemas de análisis que plantea la fuente que expondré a continuación.

\section{Problemas Para El eSTUdio de los SEÑoríos de la NOBLEZA Y CRITERIOS de ANÁlisis}

La primera pregunta que surge al afrontar el estudio de los señoríos de los nobles es cuántos nobles podían ejercer derechos señoriales en los 684 lugares para los que se dispone de información. La pregunta es bastante sencilla pero su respuesta exige plantearse una batería de problemas cuya resolución no es tan sencilla, como veremos.

1. He indicado que en las behetrías había cos niveles de señorío: el intermedio de los diviseros o naturales y el superior o señorío singular. La materialización más clara del señorío intermedio viene dada por la percepción de rentas, la tasa divisera. El señorío singular de las behetrías, aunque tiene particularidades y características distintivas, es comparable al señorio solariego en bastantes aspectos, pero resulta mucho más dificil evaluar el señorío intermedio ejercido por naturales y diviseros. Así, al valorar el poder señorial de un noble se puede contar en cuantos lugares es señor solariego $y$ en cuantas behetrías es señor singular. Esa cifra tiene un sentido evidente, aun cuando los derechos concretos de ese noble pueden variar de lugar en lugar, no sólo en función de la consideración de los lugares como behetrías o solariegos, sino de si ejerce los derechos de forma única o compartida, de las regulaciones concretas que existían en cada lugar, del volumen de sus propiedades además de sus derechos señoriales, etc. Sin embargo, resulta mucho más difícil comparar el poder señorial a ese nivel con el nivel intermedio de naturales y diviseros. Por ello, en el presente estudio no voy a referirme al señorío intermedio de las behetrías, sino sólo al señorío superior o singular.

2. El nivel de conocimientos actuales sobre las relaciones de parentesco y las familias nobiliarias no nos permite identificar siempre a los personajes cuando, como sucede tantas veces, el Becerro hace referencias genéricas a los hijos, los nietos o los herederos de un personaje determinado. Por ejemplo, es bastante frecuente que el Becerro se refiera a derechos señoriales de los hijos de Rodrigo Pérez de Villalobos; se trataría de propiedades aún indivisas tras la muerte de ese personaje.Afortunadamente, en este caso, el propio Becerro nos informa de que sus hijos eran tres: Lope Rodríguez de Villalobos, Fernando Ruiz de Villalobos y Garcí Fernández de Villalobos; además informa también que Fernando Ruiz es distinto de otro Fernando Rodríguez de Villalobos, miembro de otra rama del grupo familiar con pocas conexiones ya con

12. A.VACA LORENZO, "La estructura socioeconómica de la Tierra de Campos", en Publicaciones de la Institución Tello Téllez de Meneses, 39 (1977), pp. 229-398, y 42 (1979), pp. 203-387; I. ÁlVAREZ BORGE, El feudalismo castellano...; e I. ÁLVAREZ BORGE, Poder y relaciones sociales...

13. E. GONZÁLEZ CRESPO, "Los Velasco en el horizonte dominical de la nobleza castellana según el Libro de las Behetrías", en Anuario de Estudios Medievales, 14 (1984), pp. 323-343. C. ESTEPA en Las bebetrías castellanas, ofrecerá un análisis exhaustivo. 
los anteriores ${ }^{14}$. Los hijos de Rodrigo Pérez de Villalobos aparecen tanto con derechos conjuntos como con derechos individuales. En este caso, puesto que sabemos sus nombres con certeza, cuando aparecen en conjunto podríamos atribuir los derechos correspondiente a cada individuo. Pero es como una gota en una vaso de incertidumbres, porque es muy frecuente que no sepamos con exactitud quiénes son los hijos o los herederos de tal o cual personaje.

Hacer agrupaciones de nobles por sus apellidos toponímicos, como suele hacerse, resulta una simplificación excesiva en muchas ocasiones. El caso que he citado de los Villalobos es un ejemplo de ramas separadas bastante antes de la realización del Becerro; otros ejemplos serían los Rojas, los Padilla, los Carrillo, los Velasco, etc... Los apellidos toponímicos son menos útiles aún cuando se trata de los sectores inferiores de la nobleza porque el apellido no se transmitía de padres a hijos con la misma regularidad que entre los sectores superiores; y lo mismo sucede con los hijos ilegítimos que suelen llevar también un apellido toponímico distinto al de sus hermanastros.

3. Otro problema es el análisis de las menciones a las mujeres, porque hay muchísimos problemas para identificarlas. Los casos más frecuentes son dos. En primer lugar puede decirse que tal noble tiene derechos en tal lugar por su mujer sin que se diga quién era ella o sin dar elementos suficientes de identificación. De nuevo, los pocos casos que conocemos bien nos alertan de la importancia de los que no conocemos en absoluto. Por jemplo, Diego Pérez Sarmiento tiene la mayor parte de sus derechos en esta zona por su mujer que era María, la hermana de Pedro Fernández de Velasco.Atribuir esos derechos a los Sarmiento sería falsear un tanto los datos porque porceden de la herencia del padre de María y Pedro, muerto unos años antes de la redacción del Becerro. En este caso podemos precisar bien; pero ¿qué hacer cuando ni siquiera sabemos el nombre de la esposa del individuo en cuestión? Precisar lo precisable y no hacerlo en lo que se desconoce no resulta útil cuando lo que se pretende es obtener una visión de conjunto y sería una forma de distorsionar los datos. La segunda posibilidad es que el Becerro diga que en tal lugar hay derechos de tal mujer, Urraca Pérez por ejemplo -sin decir su apellido toponímico-, esposa o viuda de tal personaje. ¿A quién habría que atribuir esos derechos al marido muerto, cuya posición en la jerarquía nobiliaria puede llegar a conocerse, o a su esposa de quien no sabemos más que un nombre incompleto? Por ejemplo, Gómez Carrillo era un noble poderoso en la zona que ya había muerto en 1352; el Becerro dice a veces que hay derechos de sus hijos, que eran cuatro pero desconozco sus nombres, y otras veces dice que hay derechos de su viuda Urraca, sólo Urraca ¿Los derechos de Urraca son, como en el caso de María de Velasco, de su herencia familiar o de la de su marido? Gómez Carrillo es un buen ejemplo de los probemas que estoy comentando porque su hermano no llevaba el apellido Carrillo, como él, sino que era Gonzalo Alfonso de Quintana y porque seguramente tenía poco o nada que ver con otro Carrillo poderoso, Pedro Ruiz Carrillo.

El problema es que hay que adoptar siempre el mismo criterio a la hora de contabiliazar los derechos. Un análisis minucioso exigiría un gran esfuerzo, puesto que no podría hacerse sólo con el Becerro, sino que habría que trabajar con un gran volumen de fuentes hasta conseguir reconstruir las relaciones de parentesco de un gran número de individuos. La alternativa, a falta de bastantes más estudios prosopográficos rea-

14. Sobre los Villalobos, véase I. ÁLVAREZ BORGE, El feudalismo castellano..., pp. 154-156. 
lizados con criterios rigurosos, consiste en seguir a Salazar y Castro y correr el riesgo de equivocarse con él en algunas ocasiones.

\section{LOS REPARTOS HEREDITARIOS Y LOS SEÑORES DE LAS BEHETRÍAS}

De la información que da el Becerro sobre los señores laicos quiero todavía llamar la atención sobre dos aspectos, antes de dar los números y valorarlos. Primero sobre los repartos de las herencias y segundo sobre los señores de las behetrías.

Ya he mencionado que el Becerro informa de la existencia de muchos patrimonios conjuntos, de herencias no divididas. Todavía hay que mejorar nuestros conocimientos sobre las formas de reparto de la herencia entre los nobles en estos momentos de mediados del siglo XIV en los que se camina hacia el mayorazgo, aunque algunos trabajos recientes permiten tener una base relativamente sólida, al menos en lo que se refiere a la formulación teórica recogida en los códigos legales ${ }^{15}$. Como es sabido, siguiendo las normas de la tradición visigoda, en las sucesiones hereditarias todos los herederos recibían una participación en los bienes que en principio era similar. Sin embargo, cabía la posibilidad de incrementar los bienes de uno de los herederos, a menudo el varón primogénito, mediante la mejora. El origen de la mejora está en la capacidad de los testadores de disponer libremente de un quinto o un tercio de sus bienes, capacidad que muy frecuentemente fue utilizada para dotar a las instituciones eclesiásticas ${ }^{16}$. Durante el siglo XIII y el XIV la nobleza castellana -al menos la alta noblezacamina hacia una organización linajística, en el sentido que los expertos en estructuras de parentesco dan al término linaje; es decir, una estructura familiar determinada por la sucesión agnática y la primogenitura. Sin embargo, la organización linajística, los linajes en sentido estricto, tardarán aún en consolidarse definitvamente ${ }^{17}$. Se viene admitiendo

15. Entre otros véase J. MARTÍNEZ GIJÓN, "La comunidad hereditaria y la participación de la herencia en el derecho medieval español", en Anuario de Historia del Derecho Español, XXVII-XXVIII (19571958), pp. 221-303; y sobre todo P. MARTÍNEZ SOPENA, "Parentesco y poder en León durante el siglo XI. La 'casata' de Alfonso Díaz", en Studia Histórica. Historia Medieval, V (1987), pp. 33-87; P. MARTÍNEZ SOPENA, "El conde Rodrigo de León y los suyos. Herencia y expectativa de poder entre los siglos X y XII", en R. PASTOR (Comp.), Relaciones de poder, de producción y de parentesco en la Edad Media y Moder. na, Madrid, 1990, pp. 51-84; y P. MARTÍNEZ SOPENA, "Relations de parenté et héritage wisigothique dans l'aristocratie du royaume de León au XIe siècle", en VV.AA., L'Europe béritiere de l'Espagne wisigothique, Madrid, 1992, pp. 315-324; también I. BECEIRO y R, CÓRDOBA, Parentesco, poder y mentalidad. La nobleza castellana, siglos XII-XV, Madrid, 1990, pp. 62-87 y 231-250.

16. Además de los trabajos citados en la nota anterior, véase L. GARCía DE VALDEAVELLANO, "La cuota de libre disposición en el derecho hereditario de León y Castilla en la Alta Edad Media. (Notas y documentos)", en Anuario de Historia del Derecbo Español, IX (1932), pp. 129-176; y A. OTERO, "La mejora", en Anuario de Historia del Derecho Español, XXXIII (1963), pp. 5-131.

17. Las referencias clásicas para el estudio de la nobleza castellana plenomedieval son los trabajos de S. de MOXO; puede verse, entre otros, "La nobleza castellano-leonesa en la Edad Media. Problemática que suscita su estudio en el marco de una Historia Social”, en Hispania, 114 (1970), pp. 5-68; y su trabajo más importante sobre este tema "De la nobleza vieja a la nobleza nueva..."; para el período más próximo a mediados del siglo XIV, también "La nobleza castellana en el siglo XIV", en Anuario de Estudios Medievales, 7 (1970-1971), pp. 493-511; “"La sociedad política castellana...". Entre los trabajos más recientes destacan P. MARTÍNEZ SOPENA, "La nobleza de León y Castilla en los siglos XI y XII. Un estado de la cuestión", en Hispania, 185 (1993), pp. 801-822, además de los otros trabajos ya citados de este autor; M. C. GERBET, La noblesse dans le royaume de Castille. Etude sur ses structures sociales en Estrémadure, 1454-1516, París, 1979, renovador en su momento y con aportaciones válidas para el período anterior a la Baja Edad Media, y la síntesis más reciente de esta autora, Las noblezas españolas en la Edad Media. Siglos XI-XV, 
que una organización de ese tipo no llegó a generalizarse hasta finales del siglo XV o principios del siglo XVI. El término linaje aplicado a las familias nobiliarias de estos momentos de mediados del siglo XIV no debe entenderse en su sentido técnico restrictivo, sino más bien como sinónimo de grupo familiar. El mayorazgo será un elemento sustancial en la consolidación definitiva de los linajes, pero no se empieza a difundir hasta los años 70 del siglo XIV y aún tardará algunas décadas en generalizarse, a pesar de que existen casos aislados anteriores que no son sino excepciones ${ }^{18}$.

Por lo tanto, a mediados del siglo XIV, los repartos hereditatrios de la nobleza están determinados por dos tendencias parcial y aparentemente contradictorias: la participación equivalente de todos los herederos en la herencia y la primacía de uno de ellos, casi siempre el varón de mayor edad, sobre los demás. Probablemente, no todas las familias ni en todos los casos adoptaron las mismas soluciones en esa, como digo, aparente contradicción. Las situaciones biológicas concretas podian ser muy distintas en cada caso y serían uno de los condicionantes más fuertes, si no el que más.

Siendo uno de los problemas más importantes en el estudio de la nobleza plenomedieval, es mucho más difícil saber realmente cómo funcionaban en la práctica los repartos de las herencias, pasar del análisis normativo al de la evolución de los dominios. Son necesarios muchos más estudios detallados sobre casos concretos que permitan obtener conclusiones generales de mayor alcance. Sin embargo, los problemas empíricos son grandes. Muchos de los testamentos realizados por nobles antes de 1350 que han llegado hasta nosotros no incluyen una auténtica distribución de sus patrimonios territoriales ${ }^{19}$. Las escasas propiedades inmuebles que se mencionan en ellos se dirigen casi siempre a las instituciones eclesiásticas, formando parte de la quinta del testador. ¿Significa eso que, en esos casos, el testador no hacía uso de la posibilidad de mejora y que sus dominios se repartirian equitativamente entre sus herederos? Cabe imaginar que si se disponía un reparto equitativo no fuera necesario

Madrid, 1997; M. C. PALLARES y E. PORTELA, "Aristocracia y sistema de parentesco en la Galicia de los siglos centrales de la Edad Media. El grupo de los Traba", en Hispania, 185 (1993), pp. 823-840; y, sobre todo, la monografia de I. BECEIRO y R. CÓRDOBA, Parentesco, poder y mentalidad...

Como es conocido, el término linaje se usaba frecuentemente en la época, pero el que los contemporáneos hablaran de su familia o grupo familiar como su linaje no implica que sus familias fueran auténticos linajes, conforme a los métodos actuales de análisis de las estructuras de parentesco. Por otro lado, los linajes, en tanto que organización familiar linajística, poco tienen que ver con los linajes urbanos bajomedievales, organizaciones encaminadas, sobre todo, como ha mostrado J. M. MONSALVO a la acción política; véase "Parentesco y sistema concejil. Observaciones sobre la funcionalidad política de los linajes urbanos en Castilla y León (siglos XIII-XV)", en Hispania, 185 (1993), pp.937-969. Sobre la terminología del parentesco I. BECEIRO, "Parentesco y consolidación de la aristocrácia en los inicios de la corona de Castilla (siglos XI-XIID, en prensa, agradezco a la autora haberme permitido consultar el original mecanografiado.

18. Entre otros, B. CLAVERO, Mayorazgo, propiedad feudal en Castilla, 1367-1836, Madrid, 1974; y J. L. BERMEJO, "Sobre nobleza, señorios y mayorazgos", en Anuario de Historia del Derecho Español, 55 (1985), pp. 253-306. Sobre los primeros mayorazgos, J. L. MORENO NÚÑEZ, "Mayorazgos arcaicos en Castilla", en En la España Medieval, IV. Estudios dedicados al profesor don Angel Ferrari Núñez, II, Madrid, 1984, pp. 693-707; y J. P. MOLENAT, "La volonté de durer: majorats et chapellanies dans la pratique tolèdane des XIII-XV siècles", en En la España Medieval,V. Estudios en memoria del profesor D. Claudio Sánchez-Albornoz, II, Madrid, 1986, pp. 683-696.

19. Sobre los testamentos, E. PORTELA y M. C. PALLARES, "Muerte y sociedad en la Galicia medieval (siglos XII-XTV), en Anuario de Estudios Medievales, 15 (1985), pp. 189-202; M. CANTERA MONTENEGRO, "Derecho y sociedad en la Rioja bajomedieval a través de los testamentos (siglos XIII-XIV)", en Hispania, 165 (1987), pp. 33-82. 
fijarlo por escrito, pero no hacerlo cuando se optaba por mejorar la herencia de uno de los sucesores era abrir una vía potencial de conflictos muy importante. Otro tipo de textos que permiten abordar estos problemas son los repartos de bienes concretos entre los herederos, los acuerdos alcanzados mediante la participación de partidores, parientes o amigos de las partes que, teoricamente, debían ser capaces de realizar un reparto justo. Lamentablemente no se han conservado muchos textos de este tipo para el período anterior a 1350 , pero los que existen permiten saber qué bienes concretos se asignaron a cada heredero. El problema de análisis, en este caso, radica en que generalmente desconocemos la entidad de los bienes y, por lo tanto, no podemos comparar unos con otros. Pondré un ejemplo concreto. En 1311 Juan Sánchez de Velasco y su hermana Teresa Fernández se repartieron los bienes procedentes de la herencia de su madre; ambos eran hijos de Fernán Sánchez de Velasco que hizo de partidor $^{20}$. Casi todas las heredades estaban situadas dentro del territorio de la merindad menor de Castilla Vieja, en torno al curso alto del Ebro al norte de la actual provincia de Burgos. El reparto fue como sigue:Juan Sánchez de Velasco obtuvo la casa de Quincoces, la casa de Oteo, heredades en Castresaria, el solar de Gobantes, el solar de Paresotas y otras heredades en Mena; su hermana Teresa obtuvo la casa de Villamezán, la casa de Santurde, heredades en Pajarón, el solar de Cuestaurría, el solar de Bascuñuelos, el solar de Santotís, la casa de Quintanilla de Rosío y el solar de Gayangos. Aparentemente es un reparto equitativo, aunque Teresa obtuvo heredades en 8 lugares y su hermano en 6 , pero no podemos estar seguros si no conocemos la entidad de esos bienes. ¿Cómo interpretar las heredades en Mena -que no se especifican- que obtuvo Juan Sánchez?. Si se trata de un reparto equitativo ifue esta un opción tomada por tratarse de los bienes dela herencia materna? Es decir ¿podían repartirse de forma diferente los bienes procedentes del padre y los de la madre?.

Un aspecto a tener en cuenta en relación con los repartos de las herencias es que los bienes podian permanecer bastante tiempo sin ser repartidos. Por ejemplo, el reparto de los bienes de Garcí Laso I de la Vega se hizo en 1338, 12 años después de su muerte en $1326^{21}$. De esa forma es más fácil encontrar casos en que, cuando se hacen los repartos, puede haber herederos directos que ya hayan muerto y en el reparto se incluyan también los herederos y descendientes de los herederos directos, como sucede en este caso.A diferencia del anterior, el reparto de los bienes de Garcí Laso I muestra, aparentemente, que uno de su herederos, Garcí Laso II, obtuvo una mejora importante en la herencia respecto a los otros herederos. Por otros casos sabemos que, en algunas ocasiones, paralelamente al reparto de la herencia había negociaciones para recomponer determinados bloques de propiedades, mediante compras o cambios internos dentro del grupo de coherederos. El problema es que la mayor parte de las veces sólo conocemos el resultado final y ese resultado puede ser desigual en favor del heredero varón de mayor edad. Cabe preguntarse si en otras ocasiones esa situación no encubre repartos equitativos y renegociaciones internas en las que las mujeres y otros coherederos podían recibir compensaciones económicas en dine-

20. A. CASTRO GARRIDO, Documentación del monasterio de Las Huelgas de Burgos (1307-1321), Burgos, 1987, doc. 230.

21. El episodio de la muerte de Garcí Laso I en Crónica de Alfonso XI, pp. 211 ; y el documento que recoge el reparto de su bienes en R. PÉREZ BUSTAMANTE, Sociedad, economía, fiscalidad y gobierno en las Asturias de Santillana (s. XIII-XV), Santander, 1979, doc. III. 
ro o en bienes de otro tipo -ganado, joyas...- que no se reseñaron en los documentos que recogen los acuerdos finales.

Un problema relacionado con los repartos de las herencias es el relativo al ejercicio del señorío en situaciones, que sabemos frecuentes y largas, de herencias todavía no divididas. ¿Quien y como ejercía el señorío en esos casos? ¿Condicionaron en alguna medida esas situaciones -probablemente frecuentes- la evolución de las propias estructuras señoriales?

Es probable que hubiera repartos igualitarios pero también es bastante clara la existencia de lo que se viene llamando cabezas de linaje, aunque la expresión seguramente no es completamente adecuada. Me interesa poner en relación este tema con las behetrías, porque el señorío de las behetrías solía pasar en bloque a un personaje determinado. Esto nos habla, en primer lugar, de que el señorío singular de las behetrías tenía poco que ver con la participación de los campesinos. Sus formas de transmisión derivan de los mecanismos de funcionamiento patrimonial de la nobleza. Es fácil pensar que ésto se decidiera siguiendo la norma de la primogenitura masculina. Podría pensarse que las propiedades se dividieran de forma igualitaria -haciendo después las renegociaciones correspondientes- pero que en los derechos señoriales -por lo menos los de las behetrías- se primara a los varones primogénitos. En cierta medida las behetrías pudieron condicionar el desarrollo de la propia estructura jerárquica de la nobleza. Ambos elementos cabezas de linaje y señorío singular de las behetrías están claramente relacionado y creo que merece la pena seguir reflexionando sobre esa relación en la línea que propongo.

Pero la sucesión de las generaciones no siempre se ajustaba bien a estas normas de transmisión hereditaria y la sucesión no siempre era perfectemente lineal. Lope Díaz de Rojas, el cabeza del linaje que controlaba las behetrías en 1352, era el menor de sus hermanos y hay algunos elementos que permiten entrever cómo consiguió obtener la preeminencia sobre sus sobrinos (los hijos de sus hermanos mayores) y sus cuñados (los maridos de sus hermanas mayores) pero con muchos conflictos, conflictos violentos, que se concretan, por ejemplo, en la participación de unos y otros en diferentes clientelas y bandos nobiliarios y en enfrentamientos violentos ${ }^{22}$.

El rey tenía mucho que decir a la hora de determinar la sucesión en las cabezas de linaje y en los señoríos singulares de las behetrías. El favor regio era un elemento importante a la hora de obtener la preeminencia interna en los grupos familiares. La proximidad al rey daba prestigio y autoridad, poder de hecho, y permitía a quienes lo disfrutaban ser reconocidos como preeminentes entre sus parientes en situaciones conflictivas.Además, el rey podía intervenir directamente de manera que el favor regio no sólo era un elemento implícito en el juego de poder que se producía a cada sucesión, sino también un elemento explícito. Eso es lo que hay detrás de la petición de 1351 para que se repartieran las behetrías hecha por el privado Juan Alfonso de Alburquerque y del temor a un reparto injusto expresado por Juan Rodríguez de Sandoval. El canciller Pedro López de Ayala lo expone con claridad al narrar el episodio de la petición del reparto: "... ayudaba mucho á ello (al reparto) Don Juan Alfonso de Alburquerque, é por su consejo se facia, teniendo que avria gand parte dellas (de las

22. En la actualidad preparo una monografía sobre la evolución de los dominios de los Rojas durante el siglo XIII y la primera mitad del XIV. 
behetrías), lo uno por la privanza é poder que avia con el Rey, e otrosi porque era muy natural de las Bebetrias por su muger doña Isabel, que era fija de Don Tello de Meneses, que era muy natural en Campos é en otras partes:é por ende entendia él aver grand parte en las Bebetrias; é otrosi por la privanza del Rey, ca por la muerte de Don Juan Nuñez de Lara eran tornados á él muchos logares de Behetrias. $E$ non plogo á los Caballeros de Castilla de consentir en ello, teniendo que las dichas Bebetrias non se partirian igualmente; sobre lo qual ovieron muchas porfias con Don Juan Alfonso, especialmente Don Juan Rodriguez de Sandoval"23.

\section{LA DISTRIBUCIÓN DEL PODER SEÑORIAL}

Antes de ofrecer una visión detallada de los nobles que podían ejercer derechos señoriales y de discutir los posibles criterios de clasificación, es interesante exponer las cifras globales de la distribución del poder señorial. Mi objetivo en este apartado es dar una visión general de los señores en las merindades de Cerrato, Villadiego, Castrojeriz, Muñó, Burgos con Ubierna y Silos. Para sortear los problemas que he expuesto más arriba he hecho basicamente un recuento de individuos. He contado como 1 las herencias indivisas contenidas en la expresión bijos de, atribuyendo los derechos al padre. He seguido ese criterio aun cuando en ocasiones son conocidos los nombres de los hijos quienes, a su vez, pueden aparecer en otros lugares ejerciendo derechos individualmente. Eso implica una cierta distorsión -creo que pequeña- en algunas cifras y lo indicaré oportunamente más adelante al hacer el análisis detallado; pero, por otra parte, me permite disponer de un criterio unificado de recuento que, obviamente, da mayor consistencia a las cifras obtenidas. De esa forma, la realidad señorial que expondré no obedece perfectamente a una foto fija de 1352, puesto que incluye también a personajes muertos unos años antes. Siguiendo un criterio similar, he atribuido al esposo los derechos que se tienen por su mujer y que disfrutan su esposa o su viu$\mathrm{da}$, cuando así se mencionan los derechos. Por ejemplo, siguiendo con los casos que ya he mencionado, he atribuido a Diego Pérez Sarmiento los derechos que tiene por su mujer, María de Velasco, y a Gómez Carrillo los derechos que aparecen en manos de su mujer Urraca -cuyos apellidos desconozco- y en manos de sus hijos -cuyos nobres también desconozco-. Este procedimiento me permite disponer de un criterio unificador para contabilizar los lugares y al comentar cada caso con detalle haré las indicaciones oportunas.

De esta forma, las cifras que voy a dar sólo tienen un valor indicativo. Los casos problemáticos sólo podrían resolverse mediante un análisis detallado, familia por familia, para el que, como ya he indicado, no existen suficientes estudios de base. Pero no me interesa tanto ofrecer cifras que puedan considerarse totalmente exactas, como dar los datos fundamentales que muestran una tendencia general. De hecho, la pretensión de exactitud completa sería inútil porque el propio Becerro sigue teniendo demasiadas zonas oscuras.

Con los criterios que he expuesto, pueden contarse un total de 192 menciones a señores distintos con derechos en la zona estudiada. Son 57 eclesiásticos y 135 nobles laicos. Para la distribución del poder señorial hay que tener en cuenta que, del total de

23. Crónica de Pedro I, pp. 417; véase también C. ESTEPA, "Las behetrías en el canciller...". 
684 lugares para los que el Becerro ofrece información, hay tres lugares cuya situación señorial se desconoce y nada menos que 63 behetrías sin señor, aunque 4 de ellas son condominios diversos con participación de behetría. Por lo tanto, la información disponible se refiere realmente a 622 lugares. Aunque, según vengo insistiendo, las cifras sólo tienen un valor indicativo, me parecen muy significativas y nos hablan de una señorialización muy intensa. La media del reparto teórico sería de 3'23 lugares por cada señor, pero la distribución real es la siguiente:

-87 señores, $19^{(a)}$ eclesiásticos y $68^{(b)}$ laicos, con derechos sólo en 1 lugar.

-52 señores, 18 eclesiásticos y 34 laicos, con derechos entre 2 y 4 lugares.

-22 señores, 7 eclesiásticos y $15^{(\mathrm{c})}$ laicos, con derechos entre 5 y 9 lugares.

-13 señores, 6 eclesiásticos y $7^{(\mathrm{d})}$ laicos, con derechos entre 10 y 14 lugares.

-7 señores, 5 eclesiásticos y 2 laicos, con derechos entre 15 y 19 lugares.

-4 señores, todos ellos laicos, con derechos entre 20 y 24 lugares.

-4 señores, 1 eclesiástico y 3 laicos, con derechos entre 25 y 29 lugares.

-2 señores, 1 eclesiástico y 1 laico, con derechos entre 30 y 34 lugares.

-1 señor, laico, con derechos en más de 35 lugares (50 lugares).

Los desequilibrios son perfectamente claros. Mi objetivo en este artículo son los nobles laicos, pero me parece interesante resaltar que las cifras son igualmente desequilibradas tanto para los señores laicos como para los eclesiásticos. El 75'55\% de los primeros y el $6491 \%$ de los segundos podían ejercer derechos en menos de 5 lugares. Para los laicos esa cifra expresa 102 de los 135 nobles que he contabilizado, mientras que los 33 restantes ejercían derechos en 5 ó más lugares. 89 de los 135 nobles ejercían derechos sólo en uno o dos lugares, mientras que sólo 9 se proyectaban sobre más de 20 lugares ${ }^{24}$.

La conclusión, coincidente con la ya expresada a partir de otros estudios sobre ámbitos más reducidos, es que había un gran número de nobles que podían ejercer derechos señoriales en la zona, pero la gran mayoría lo hacían sobre un número muy reducido de lugares, sólo uno o dos, mientras que unos pocos nobles tenían una proyección señorial realmente importante ${ }^{25}$.

Como he indicado más arriba, en la zona estudiada había un total de 63 behetrías sin señor. Es un cifra importante que no puede pasarse por alto a la hora de analizar la distribución del poder señorial de la nobleza, porque representan el 22 '99\% de las

(a) Incluye una referencia a la orden del Temple (XI-53) y otra genérica a clérigos (XI-114).

(b) Incluye las siguentes referencias: escuderos de Canillas (I-88), escuderos de Baltanás (I-55), escuderos de Torquemada (I-8), hidalgos (XI-114) y la villa de Castrojeriz (XI-67).

(c) Incluye al concejo de Burgos

(d) Incluye al rey y la reina, señores de 13 y 14 lugares respectivamente.

24. Para los eclesiásticos las cifras son de 30 de los 57 señores sobre uno o dos lugares y sólo dos con más de 20 lugares. Con derechos en menos de 5 lugares se cuentan 37 señores eclesiásticos y 20 con más de 5 lugares. Por lo tanto, los desequilibrios son también perfectamente claros pero algo menos acusados que entre los nobles laicos.

25. I. ÁLVAREZ BORGE, el feudalismo castellano..., pp. 184-185; e I. ÁLVAREZ BORGE, POder y relaciones sociales..., pp. 242-248. 
274 behetrias y condominios con participación de behetría. Es decir, desconocemos quienes eran los señores de alrededor de la cuarta parte de las behetrias de la zona. Antes de nada, es necesario explicar qué indica el Becerro. En esas 63 behetrias, como en casi todas las restantes, había dos niveles de señorio, el intermedio y el singular. El texto indica generalmente el nombre de los naturales o diviseros pero omite el del señor singular; sin embargo, en bastantes de esos lugares se indican las rentas que los campesinos pagaban al señor. Por ejemplo, del lugar de Hurones, en la merindad de Burgos con Ubierna, el Becerro dice: Este logar es bebetria e son naturales del los Manrriques e los de Velasco e los Carriellos e los Guzmanes e los de Haro e don Nunno, y más adelante Dan al sennor que tiene el lugar por infurçion... ${ }^{26}$, pero no se dice el nombre del señor que recibia la infurción. Una primera interpretación podría considerar que en esas behetrias no existía el nivel del señorio singular. Sin embargo, aunque podia haber algunos casos de behetrías sólo con diviseros o naturales, no creo que esa sea la situación de la mayor parte de estos lugares. Expresiones como la citada para Hurones implican que en efecto existía normalmente un señor singular del lugar. Habría, pues, que buscar otras interpretaciones tendentes a explicar porqué el señor no figura en el texto. En ese sentido, podría pensarse que estos casos obedecen a errores en la redacción del Becerro, defectos en la tradición manuscrita del texto o a otras circunstancias casuales. Sin embargo, se trata de un número demasiado elevado de casos. Si el señor existía y los pesquisidores no recogieron su nombre puede ser porque los campesinos a quienes interrogaron en su pesquisa lo desconocieran. No me parece del todo improbable que en algunos lugares los campesinos no supieran exactamente quién era su señor en ese momento. Muchos de ellos probablemente no lo habían visto jamás, sobre todo si se trataba de los nobles más poderosos que podían vivir en otras zonas del reino. Pero ese tipo de situaciones me parecen más probables en momentos determinados como, por ejemplo, tras la muerte del señor anterior, cuando todavia no se había repartido su herencia; o en momentos de conflictos entre varios señores por el señorío de un lugar o un grupo de lugares, conflictos ligados también muchas veces a los repartos hereditarios. No hay que olvidar que una de las causas para solicitar el reparto de las behetrías como solariegos en las Cortes de Valladolid de 1351 era que eran ocasion por dó los Fijosdalgo avían sus enemistades ${ }^{27}$; es decir, los conflictos en torno al señorío de las behetrias. En ese tipo de situaciones es posible que los campesinos no supieran realmente quién era su señor, aunque recordaran perfectamente la renta consuetudinaria que le debian pagar en reconocimiento de señorio.

\section{Criterios para la clasificación de la nobleza a mediados del siglo XIV}

Para la clasificación de los nobles voy a utlizar, en primer lugar, el criterio de establecer tres grupos que responden a las calificaciones más frecuentes en la época: ricos-hombres, caballeros y escuderos. Esa es la clasificación que hacían los contemporáneos en cuanto al estatus de los nobles. Existían otros términos para referirse a

26. Becerro, XIII-41 Las behetrías que he contabilizado sin señor son: $1-18 \cdot \mathrm{VI}-3,4,5,6,7,8,9,10,11$ $12,13,16,23,26,33,37,39,41,42,45,47,48,53,54 ; X 1-3,6,7,10,30,37,44,51,52,57 ;$ XII-1, 2, 3, 3. 1, 4, $5,12,13,15,16,17,20,21,22,23 ;$ XIII-34, 35, 41, 42, 43, 50, 51, 52, 62; y XV-19, 22, 107 y 107.1

27. Crónica de Pedro 1, pp. 417. 
Alfonso XI y de Pedro I, que prefirieron rodearse de otros nobles en su entorno inmediato que no eran ricos hombres ${ }^{30}$; es el caso de la mayoría de los privados de Alfonso XI y de Pedro I, excepto, en el último caso, Juan Alfonso de Alburquerque. Las crónicas dicen también que ser rico-hombre significaba tener pendón y caldera. Tener pendón parece claramente relacionado con la posibilidad de tener sus propios contingentes militares; los ricos-hombres tenían, podría decirse, sus propias huestes y con ellas formaban parte del ejército regio; no formaban parte estrictamente de la hueste regia. Más difícil es saber qué significa tener caldera. Parece tratarse de la expresión en los símbolos heráldicos de la capacidad para mantener a sus propios vasallos. Eso parece razonable si pensamos que otra caracteristica de la rica-hombría era la de situarse inmediatamente por debajo del rey en la pirámide feudovasallática. La caldera en los símbolos heráldicos de los ricos hombres era probablemente lo que los distinguía del resto de los nobles. Algunos relatos de las crónicas indican claramente la relación entre la rica hombría y el pendón y la caldera como sus símbolos expresivos. Durante la minoría de Alfonso XI, hacia 1320, don Juan, el hijo del infante don Juan, mandó matar en Burgos, entre otros, a Juan Rodríguez de Rojas; de él dice la Crónica de Alfonso XI que era bombre de grand poder, et fijo de don Joan Rodriguez de Rojas, que ovo pendon et caldera ${ }^{31}$. Alcanzada ya la mayoría de edad, durante unos años Alfonso XI tuvo como privado a Alvar Núnez Osorio, uno de los caballeros de su consejo. Siendo uno de los hombres más poderosos del reino, su estatus nobiliario no se correspondía con su poder, por ello Alvar Núñez solicitó al rey que podiese tomar solar et voz convirtiéndole en rico hombre. Accedió a ello Alfonso XI otorgándole el título de conde, el señorío de Cabrera y Ribera y nuevas enseñas heráldicas, Et de allí adelante (Alvar Nuñez) traxo pendon et caldera, et casa, et facienda de Conde ${ }^{32}$. Otro caso de elevación a la rica hombría de un caballero, narrado por las crónicas, es el de Alfonso Fer nández Coronel a comienzos del reinado de Pedro I, en 1350. El privado de Pedro I era entonces Juan Alfonso de Alburquerque, a quien Alfonso Fernández Coronel solicitó ayuda para que el rey le ficiese rico ome, é le diese pendon é caldera: ca estonces, el dicho Don Alfonso Ferrandez era Caballero, é muy bueno, man non le tenian por rico omme; en efecto, el rey le fizo rico ome, é le dió pendon é caldera segund la manera é costumbre de Castilla ${ }^{33}$. Otro aspecto que quiero indicar es que el grupo de nobles que se consideraban ricos-hombres era un grupo cerrado y estable. Era una calidad que se heredaba, probablemente aquí sí por la vía de la primogenitura. Dudo que todos los hermanos tuvieran la consideración de ricos-hombres sino sólo los cabezas de los linajes. El rey podía elevar a un personaje determinado a la rica-hombría como hizo Alfonso XI con su privado Alvar Núñez Osorio, pero dudo que pudiera quitar esa condición a quien la tuviera por herencia.

El segundo escalón en la jerarquía nobiliaria era la caballería. Hacia 1350, para la nobleza territorial ser caballero significaba haber sido armado caballero y expresaba

30. S. de MOXO, "La sociedad política castellana..."; S. de MOXO, "La promoción política y social de los 'etrados' en la Corte de Alfonso XI", en Hispania, 129 (1975), pp. 5-29; 5. de MOXO, "La elevación de los

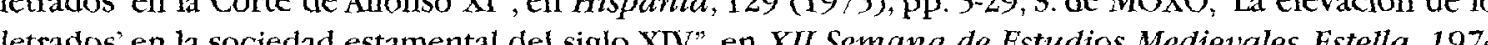
Pamplona, 1976, pp. 183-215; J. SÁNCHEZ-ARCILLA, Alfonso XI (1312-1350), Palencia, 1995; y L.V. DÍAZ MARTín, Los oficiales de Pedro I...

31. Crónica de Alfonso XI, pp. 193

32. Crónica de Alfonso XI, pp. 210-211

33. Crónica de Pedro I, pp. 423-424. 
un gradỏ jerárquico dentro de la nobleza. La caballería medieval castellana siempre fue polimórfica y, en correspondencia, el término se utilizaba en relación con otras realidades como las ya indicadas relativas a la nobleza urbana. Sin embargo, desde la segunda mitad del siglo XIII, como queda magníficamente expresado en Las Partidas y, sobre todo, durante el reinado de Alfonso XI, se asiste a un gran desarrollo de la caballería en el sentido de lo que algunos autores denominan caballería de espuela dorada. Dentro de la nobleza, algunos individuos eran armados caballeros y desde entonces recibían esa calificación distinguiéndose de quienes no habían realizado tal ceremonia y, por lo tanto, no eran caballeros -en ese sentido-. Es un fenómeno paralelo a otras zonas de Europa. La formación de la Orden de la Banda y la gran ceremonia de la coronación de Alfonso XI, con el rito de iniciación a la caballería que protagonizaron muchos nobles son hechos bien expresivos. En esa ceremonia el rey armó a sus caballeros y algunos ricos hombres presentes en la coronación hicieron lo mismo ${ }^{34}$. El auge de la caballería en esos momentos, así definida, es la expresión de un proyecto político de Alfonso XI en su relación con la nobleza, con los distintos sectores de la nobleza, no es sólo un fenómeno ideológico, aunque óbviamente también lo es en gran medida. Los distintos elementos en torno a la caballería y el ideal caballeresco ceremonia de toma de armas, relaciones entre el caballero y quien le entrega las armas, los elementos religiosos, culturales, etc.- son bien conocidos y no insistiré ahora en ellos ${ }^{35}$. El auge de la caballería y lo que conlleva de proyecto político quedaron bien reflejados en las crónicas regias, especialmente en la de Alfonso XI, que muestra gran cuidado en calificar a unos u otros individuos como ricos hombres o caballeros o escuderos.

Los escuderos serían el tercer escalón en la jerarquía nobiliaria.Aquí la terminología es menos precisa y podría plantearse si sería mejor utilizar el término hidalgos para este tercer escalón, y reservar el término escuderos para situaciones de dependencia respecto de otros nobles. Los términos son polisémicos y no pretendo realizar un análisis del léxico, que considero insuficiente para analizar las realidades sociales. El término hidalgos tiene un contenido más amplio, según he indicado, puesto que todos los nobles eran hidalgos aunque, al existir otros términos para otros sectores de la nobleza, el de hidalgos acabó quedando vinculado a los sectores inferiores de la nobleza. Escuderos serían todos los nobles que no eran caballeros y, por supuesto, tampoco eran ricos hombres.

Esta estructura jerárquica refleja la estratificación de la nobleza a mediados del siglo $\mathrm{XIV}$; es una jerarquía de estatus. Pero también es una jerarquía de edad; es un asunto bien conocido y no insistiré ahora en ello $^{36}$. El paralelismo con otras zonas europeas que

34. Crónica de Alfonso XI, pp. 235-237; L.TADEO VILLANUEVA, "Memoria sobre la Orden de Caballería de la Banda de Castilla", en Boletín de la Real Academia de la Historia, 72 (1918), pp. 436-465 y 552-574.

35. Las referencias pueden ser muy abundantes; entre otros, véase S. MORETA, "El caballero en los poemas épicos castellanos del siglo XIII", en Studia Histórica. Historia Medievas, I (1983), pp. 5-28; J. L. MARTÍN y L. SERRANO-PIEDECASAS, “Tratados de caballería. Desafios, justas y torneos”, en Espacio, Tiempo y Forma. Historia Medieval, 4 (1991), pp. 161-242; y J. D. RODRÍGUEZ VELASCO, El debate sobre la caballería en el siglo XV. La tratadística caballeresca en su marco europeo, Valladolid, 1996, con abundantes referencias y análisis de las obras y autores más importantes.

36. S. M. BELMARTINO, "Estructuras dela familia y 'edades sociales' en la aristocracia de León y Castilla según las fuentes literarias e historiográficas”, en Cuadernos de Historia de España, XLVI-XLVIII (1968), pp. 256-328. 
también vieron cristalizar estructuras nobiliarias jerarquicas similares es muy claro ${ }^{37}$. Por otro lado, esta jerarquía no llegó a configurarse plenamente en Castilla. Entre las razones estarían el caracter polimórfico de la caballería en Castilla y la sustitución del proyecto político que la sustentaba por otro con matices diferentes. Esta jerarquía sirve para proyectar sobre ella una análisis de la nobleza a mediados del siglo XIV, pero no pretendo indicar que sirva también para el siglo XIII o para el siglo XV.

Esta jerarquía refleja el estatus de cada noble, pero no es idéntica a la jerarquía de poder, había caballeros más poderosos que algunos ricos-hombres, ni por supuesto es idéntica a la jerarquía de riqueza. Estatus, poder y riqueza son aspectos con interrelaciones evidentes, pero no son idénticos.Ahora me interesa poner en relación esa jerarquía nobiliaria con el poder señorial que refleja el Becerro en la zona que he estudiado.

Para analizar el poder señorial hay que conjugar la jerarquía de estatus nobiliario con otras categorías como pueden ser alta nobleza, nobleza regional, nobleza comarcal y nobleza local. Me parece que es posible definir la situación de cada individuo en función de su situación según los dos criterios. Por ejemplo, un caballero como Juan Martínez de Leiva podía ser un miembro de la alta nobleza en cuanto que era privado del rey. Un escudero que no hubiera accedido todavía a la caballería podía tener incluso una proyección regional. Etc...

En función de estos dos criterios de análisis podemos ver quiénes eran los señores en las merindades de Cerrato, Villadiego, Castrojeriz, Muñó, Burgos con Ubierna y Silos en 1352.

\section{El PODER SEÑorIAL DE LOS NOBLES A MEDIADOS DEL SIGLO XIV}

\subsection{Señores de más de 20 lugares}

En las seis merindades en las que centro mi análisis había 9 señores laicos que tenían derechos señoriales en más de 20 lugares en 1352; ellos forman el grupo de nobles más poderosos. En primer lugar figura Juan Rodríguez de Sandoval, señor de 50 lugares, 39 de los cuales eran behetrías, lo que explica su protagonismo en la oposición al reparto de las behetrías que pretendía Juan Alfonso de Alburquerque en las Cortes de Valladolid de 1351. Era también señor de 11 solariegos pero sólo en 3 de ellos ejercía sus derechos de forma única; en los otros 8 los compartía con otros señores laicos o eclesiásticos en diversas combinaciones de solariego compartido o de condominio de solariego y abadengo. Bastantes de sus lugares solariegos presentan un señorío muy fragmentado -en 6 de esos 11 lugares había 3 o más señores- lo que remite sus derechos, con toda probabilidad, también a situaciones anteriores de behetría. Cuando el cronista Pedro López de Ayala decía de Juan Rodríguez de Sandoval, al narrar su oposición al reparto de las behetrías, que era muy gran Caballero é natural de las Bebetrías ${ }^{38}$, estaba describiendole perfectamente. Además de sus señoríos,

37. Las referencias bibliográficas son abundantísimas; entre las obras recientes que además dan noticia de los trabajos anteriores, puede verse M. KEEN, La caballería, Madrid, 1986; J. FLORI, L'Essor de la Chevalerie, XIe-XIIe siècles, Ginebra, 1986; y P. COSS, The Knight in Mdieval England, 1000-1400, Phoenix Mill-Gloucestershire, 1995.

38. Cronica de Pedro I, pp. 417. 
Juan Rodríguez de Sandoval contaba también con un lugar en encomienda del monasterio de Valbuena ${ }^{39}$. Juan Rodríguez de Sandoval concentraba su poder en la zona occidental de la merindad de Castrojeriz (11 lugares), en la de Villadiego ( 7 lugares), donde se encontraba el lugar de Sandoval de la Reina, nucleo inicial, probablemente, del patrimonio de su familia, puesto que adoptaron ese nombre como apellido, y, sobre todo, en la merindad de Cerrato (28 lugares). Los antecedentes familiares de este personaje son mal conocidos. Los Sandoval parecen un grupo familiar muy amplio, con muchos paralelismos con los Rojas y los Carrillo. Juan Rodríguez está muy por encima de los otros Sandoval conocidos, en cuanto a derechos señoriales. Posiblemente obtuvo derechos importantes por vía femenina, bien a través de su esposa o esposas, bien procedentes de su madre. Un caso interesante es el único solariego de que dispone en el sector oriental de la merindad de Castrojeriz. Se trata de Villamiel de la Sierra, lugar de abadengo y solariego compartido con un total de 5 señores ${ }^{40}$. El abadengo es de la abadesa del monasterio de Renuncio y es posible que no se trate de derechos del monasterio sino de derechos patrimoniales de la abadesa. Los señores solariegos son varios nobles laicos que poseen sus derechos en varios casos por sus mujeres respectivas; son las mujeres de Juan Rodríguez de Sandoval, Diego Pérez Sarmiento y Sancho Martínez de Leiva, y junto a ellos figura Pedro Fernández de Velasco por sí mismo, no por su mujer ¿Qué tenían en común las esposas de Sandoval y Leiva con María de Velasco -mujer de Diego Pérez Sarmiento- y con Pedro Fernández de Velasco -hermano de María- y, si acaso, con la abadesa de Renuncio? Quizás cuando lo sepamos podremos desvelar parte de la incógnita del origen del poder señorial de Juan Rodríguez de Sandoval.

El siguiente señor más poderoso en la zona era Garcí Fernández Manrique. A diferencia del de Sandoval, que era caballero, Garcí Fernández Manrique era un rico hombre y sus antecedentes familiares son $\operatorname{conocidos}^{41}$. Las características de sus señoríos y las zonas por donde se extendían también son bien diferentes. Garcí Fernández Manrique era señor de 15 behetrías -en 12 como señor único y en 3 compartiendo sus derechos- y de 19 solariegos -10 únicos y 9 compartidos. Su poder se centraba en las merindades de Burgos (17 lugares) y de Villadiego (12 lugares), lo que da cuenta de la procedencia de buena parte de sus derechos de los Manzanedo y, en menor medida, también de los Villamayor ${ }^{42}$.

Tras Garcí Fernández Manrique se sitúa Juan Martinez de Leiva, personaje bien conocido por su proximidad al rey Alfonso $\mathrm{XI}^{13}$. Había muerto ya cuando se redactó el Becerro y sus bienes aparecen indivisos entre sus hijos. Fué señor de 24 solariegos y

39. Valbuena de Duero en la merindad de Cerrato; Becerro, I-1.

40. Becerro, XI-94. De otro de sus solariegos, Solarana, la única villa que posee en la merindad de Muñó, dice el Becerro que era un lugar realengo que Alfonso XI dio al de Sandoval; Becerro, XII-39.

41. Recientemente, G. Martínez ha indicado que los Mantique no proceden de una rama de los Lara, como venía siendo admitido generalmente, sino de los Manzanedo; G. MARTÍNEZ DÍEZ, El Monasterio de Fredeval, el Castillo de Sotopalacios y la Merindad y Valle de Ubierna, Burbos, 1997. Sobre los Manrique también R. M. MONTERO TEJADA, Nobleza y sociedad en Castilla. El linaje Manrique (siglos XIV XVT), Madrid, 1996.

42. Sobre sus derechos en la merindad de Burgos, véase I. ÁLVAREZ BORGE, El feudalismo castellano..., pp. 156-157 y 163; su relación patrimonial con los Villamayor en I. ÁLVAREZ BORGE, Poder y relaciones sociales..., pp. 142.

43. S. de MOXO, “La sociedad política...”, pp. 257-259. 
una behetria, que aparecen en manos de sus hijos, más otros 2 lugares de solariego compartido o condominio en los que se menciona a su viuda Juana. No sé si estos dos lugares pertenecían en realidad al patrimonio de Juana o al de su esposo. Sin embargo hay que decir que entre su patrimonio se encontraba Espeja con sus 11 aldeas, 5 de las cuales estaban yermas, y que en la mayor parte de los lugares compartía sus derechos con otros señores, en concreto en Espeja el Becerro menciona 5 señores más, además de los hijos de Juan Martínez de Leiva ${ }^{44}$. El propio Becerro informa en este caso de quienes eran los hijos de Juan Martínez de Leiva y su caso es un buen ejemplo de lo complicado que podía ser el asunto de las sucesiones. Parece que casó al menos en dos ocasiones, con Guiomar y con Juana, y con ambas tuvo siete hijas: María González que casó con Pedro López de Padilla, otra hija que casó con Garcí Fernández Manrique, otra hija que casó con Tello García de Toledo, la abadesa de Santa Clara de Burgos, la abadesa de Fuencaliente, Sancha García que casó con Garcí Suárez de Toledo y con quien tuvo a Gómez García (el heredero aparentemente de Juan Martínez de Leiva en 1352), y otra hija monja en el monasterio de Cañas.Además de los lugares en que podía ejercer el señorio, la viuda de Juan Martínez de Leiva disponía también de otros dos lugares que pertenecian a los monasterios de Arlanza y Silos ${ }^{45}$. Los señorios de Juan Martínez de Leiva estaban, sobre todo, en la zona sur de la merindad de Silos y probablemente son derechos integrados por vía femenina.

El siguiente señor más poderoso en la zona era don Nuño de Lara, también señor de Vizcaya en esos momentos. Era señor de 26 lugares en la zona, 17 behetrías y 9 solariegos, y en la mayor parte de sus villas, 22 de las 26 , era el único señor del lugar. Su poder se extendía por la merindad de Silos ( 8 lugares), el sector occidental de la merindad de Castrojeriz ( 5 lugares) y las merindades de Cerrato y Muñó ( 6 lugares en cada una $)^{46}$. En Muñó se encontraban la villa de Lerma y sus cuatro aldeas dependientes; Lerma era el núcleo del poder de los Lara en la zona y su lugar de residencia habitual desde la segunda mitad del siglo XIII al menos.

Pedro Fernández de Velasco tenía derechos en esta zona sobre 24 lugares, 6 behetrías y 18 solariegos compartidos o condominios de solariego y abadengo. La nota más característica de sus señoríos, que en esta zona se encuentran en la merindad de Silos (19 lugares) y en el sector oriental de la de Castrojeriz ( 5 lugares), es el alto grado de fragmentación de sus derechos por cuanto sólo era señor único en las 6 behetrias y en uno de los 18 solariegos. En 12 de sus 24 lugares, Pedro Fernández de Velasco debía compartir sus derechos con otros dos señores o más. Estrechamente relacionados con sus derechos están los de su madre Mayor de Castañeda, con quien compartía derechos en un lugar, y los de su cuñado Diego Pérez Sarmiento, esposo de su hermana María de Velasco, con quien compartía derechos en los 11 lugares que posee Diego. Los derechos de Diego Pérez Sarmiento en esta zona son siempre atribuibles a su esposa María de Velasco, formando parte de la herencia de Fernán Sánchez de Velasco, padre de María y Pedro Fernández de Velasco. La expansión patrimonial de los Velasco en esta zona durante la primera mitad del siglo XIV es relativamente bien conocida y, como sucede en otros casos, procede de enlaces matrimoniales con mujeres de los grupos familiares de los Carrillo, los Guzmán y los

44. Becerro, XV-88.

45. Se trata de Cañicera y Cubillas, ambos en la merindad de Silos; Becerro, XV. 93 y 96.

46. Un análisis detallado en S. R. DOUBLEDAY, The Laras..., pp. 432.461 y $494-539$. 
Castañeda ${ }^{\text {i7 }}$. En cuanto a las 6 behetrías que posee Pedro Fernández de Velasco en la merindad de Silos y en un solariego compartido de Castrojeriz, sus derechos estaban vinculados a la casa de Salas de los Infantes ${ }^{48}$; adquisisicón reciente procedente de Diego López de Haro y centro del patrimonio de esta rama de los Velasco en la zona.

Tras Pedro Fernández de Velasco, aparece Lope Diaz de Rojas, señor de 23 lugares: 19 behetrías, 3 de ellas compartidas, y 4 solariegos, uno de ellos compartido. Además de esos lugares, tenía también otro lugar que pertenecía al monasterio de Oña ${ }^{49}$. Su caso presenta bastantes paralelismos con Juan Rodríguez de Sandoval; como él, Lope Díaz de Rojas es miembro de un grupo familiar muy amplio, y como él es, básicamente, señor de behetrias. También, como en el caso de Juan Rodriguez de Sandoval, Lope Díaz destaca muy por encima del resto de los miembros de su grupo familiar y hay que pensar, igualmente, que buena parte de sus derechos proceden de enlaces matrimoniales. Sus derechos en la zona que estudio se concretan en las merindades de Villadiego (10 lugares) y el sector occidental de la merindad de Castrojeriz (12 lugares), zonas en las que sus intereses también coincidian con los del de Sandoval.

Pedro Ruiz Carrillo también era señor de 23 lugares: 9 behetrías, una de ellas compartida, y 14 solariegos, 12 de ellos condominios de abadengo y solariego compartido. Entre sus solariegos se encuentra Espeja de San Marcelino y sus 11 aldeas dependientes, lugar que, como ya he indicado, tenía un señorio fuertemente compartido, con un total de 6 señores $^{50}$. Espeja estaba en la merindad de Silos, zona en la que se situaban la mayor parte de los lugares de Pedro Ruíz Carrillo (12 lugares), seguida de la merindad de Muñó ( 5 lugares). En la merindad de Muñó estaba Villavieja, de curya casa dependían los lugares de Quintanaseca y San Pedro de Vellota. Quintanaseca aparece calificada en el Becerro como realengo, pero la casa de Villavieja de la que dependía estaba realmente en manos de este personaje ${ }^{51}$. Como sucede con la casa de Salas en manos de Pedro Fernández de Velasco, el contenido exacto de la casa de Villavieja se desconoce. Podria tratarse de un centro heredero de la antigua sede del palacio o bodega regia del alfoz altomedieval de Muñó. Entre los lugares dependientes de Pedro Ruiz Carrillo he contabilizado también la behetria de Hontoria de Yuso, donde el Becerro no registra derechos suyos, sino de su mujer Urraca ${ }^{52}$. Es un caso infrecuente, porque las mujeres casi nunca ocupaban el señorio singular de las behetrías. Parece que se trata de un lugar procedente del patrimonio de Urraca, pero Pedro Rúz Carrillo es señor de otras dos behetrías muy próximas sin que en esos otros casos se mencione a su mujer ${ }^{33}$. El Becerro también incluye una behetria, Villacisla en la merindad de Muñó, cuyo señor es Garcí Laso Carrillo, hijo de Pedro Rúz Carrillo y de Urraca Laso, hermana de Garcí Laso de la Vega ${ }^{54}$.

47. E. GONZÁLEZ CRESPO, Elevación de un linaje nobiliario castellano en la Baja Edad Media: los CRESPO, "El patrimonio de los Velasco..." C. JULAR,"Dominios señoriales y clientelas..."; C.JULAR,,"Familia y clientela...; e I. ALVAREZ BORGE, Poder y reiaciones sociales..., pp. 145-148.

48. Becerro, XI-94 y XV-5, 10,37 y 18. Sobre la casa de Salas véase J. ESCALONA, "Arcaismos y novedades...

49. La Nuez de Abajo en la merindad de Castrojeriz; Becerro, XI-99.

50. Becerro, XV 73

51. Becerro, XII-48 y 51

52. Becerro, XI-62

53. Becerro, $\mathrm{XI}-60$ y 61

54. Becerro, XII-27; Crónica de Pedro I, pp. 413 
El apellido Carrillo corresponde a un grupo familiar muy amplio, similar a los Sandoval o los Rojas y las relaciones de parentesco entre algunos de los que lo llevaban a mediados del siglo XIV podian ser muy lejanas. El siguiente señor en importancia en la zona que estudio era Gómez Carrillo, que posiblemente no pertenecía a la misma rama del grupo familiar que Pedro Ruíz Carrillo. Gómez Carrillo ya había muerto en 1352 y sus propiedades aparecen en manos de sus herederos, de su esposa Urraca y de sus hijos, cuyos nombres desconozco. Atribuyéndole tanto los derechos que aparecen en manos de su esposa como los de sus hijos, tenemos que Gómez Carrillo había sido señor de 22 lugares: 20 solariegos, todos ellos compartidos con otros señores, y dos behetrías. Su viuda disponía también de otro lugar que pertenecía al monasterio de Silos ${ }^{55}$. La mayor parte de los derechos señoriales de Gómez Carrillo en la zona que estudio se concentraban en la merindad de Silos (19 lugares) y pueden distinguirse dos bloques. Por un lado, Espeja y sus aldeas, donde compartía derechos, entre otros, con Juan Martínez de Leiva y con Pedro Ruíz Carrillo. Por otro lado, un grupo de 6 lugares al norte de la merindad, próximos a las zonas riojanas, que comparten los mismos señores, lo que habla de una evolución común. Se trata de Huerta de Abajo, Tolbaños de Abajo, Huerta de Arriba, Quintanilla de Urrilla, Riocavado de la Sierra y Barbadillo de Herreros, solariegoss compartidos cuyos señores eran Pedro Fernández de Velasco y su hermana María,Juan Sánchez de Velasco, los hijos de Juan Martínez de Leiva y los de Gómez Carrillo ${ }^{56}$. En 17 de los 22 lugares donde tuvo derechos Gómez Carrillo aparece también como señor Juan Martínez de Leiva -sus hijos-; es probable, pues, que hubiera lazos de parentesco entre ambos ${ }^{57}$.

Cerrando la lista de los señores más poderosos se encuentra don Pedro de Haro, señor de 20 lugares en esta zona: 11 behetrías y 9 solariegos. Como sucedía con Nuño de Lara, una nota característica de los señoríos de Pedro de Haro es que ejerce sus derechos de forma exclusiva en la mayor parte de los lugares (15 de sus 20 lugares); aunque Pedro comparte sus derechos en varias behetrías correspondiendo, básicamente, a Melgar de Fernamental y sus tres aldeas, en el sector occidental de la merindad de Castrojeriz ${ }^{58}$.Además del núcleo de Melgar, la mayor parte de los lugares de don Pedro en esta zona se encuentran en la merindad de Silos (14 lugares) y parecen proceder del matrimonio de su antecesor Diego López de Haro con la infanta Violante, hija de Alfonso X. El Becerro lo indica en algunos casos $^{59}$. Por lo tanto, no se trata de derechos que puedan considerarse tradicionales de la casa de Haro, sino adquiridos a finales del siglo XIII. El Becerro indica en varias ocasiones que don Pedro era hijo de un Diego de $\mathrm{Haro}^{60}$, sucesor de aquél que casó con la infanta doña Violante. Creo que

55. Tormillos en la merindad de Silos; Becerro, XV-76.

56. Becerro, XV-44, 45, 46, 47, 48 y 49. A esos lugares habría que añadir Tobaños de Arriba (XV-43), donde el Becerro no menciona a los hijos de Gómez Carillo pero sí a los otros señores. Esa combinación de señores presenta otras pequeñas modificaciones que bien podrían deberse a errores en la redacción o tradición del Becerro; así en Huerta de Arriba (XV-46) falta Juan Sánchez de Velasco y en Quintanilla de Urrilla (XV-48) los hijos del de Leiva.

57. La cifra podría aumentarse teniendo en cuenta lo dicho en la nota anterior sobre Tolbaños de Arriba y Quintanilla de Urrilla.

58. Becerro, XI-58.

59. Becerro, XI-101 y XV-106.

60. Por ejemplo, en Becerro, XV-102. Por su parte, S. de MOXO le consideraba hijo de Fernando de Haro y nieto de Diego López de Haro V; "De la nobleza vieja...”, p. 52 
puede identificarse al padre de Pedro de Haro con el esposo ya muerto de doña Sancha, señora destacada también en la merindad de Silos donde tenía 6 lugares, y con el personaje que poseía la casa de Salas antes de que la adquiriera Pedro Fernández de Velasco. Si esa relación es cierta, Diego López de Haro -padre de don Pedro y esposo de doña Sancha- debió ser uno de los señores más poderosos en la merindad de Silos antes de 1350, puesto que a los 20 lugares de don Pedro habría que sumar 6 de Sancha y 5 vinculados a la casa de Salas. Por otra parte, el Becerro informa que uno de los solariegos de don Pedro estaba en manos de la infanta doña Blanca. Se trata de Pinillos de Esgueva: Este logar era de don Pedro fiio de don Diego, e fue dado a la infanta donna Blanca en donadio. La infanta poseía además otro lugar muy próximo, Cabañes de Esgueva, donde no se indica el origen de sus derechos, pero la infurción de Cabañes la recibía también don Pedro, quien en el apartado de las rentas aparece calificado como su sennor (del lugar). Por lo tanto, Cabañes también procedía del mismo bloque patrimonial ${ }^{61}$.

Pedro de Haro cierra el grupo de nobles más poderosos con derechos señoriales en más de 20 lugares. Este grupo está integrado por 9 nobles, entre los cuales encontramos 3 ricos hombres: Nuño de Lara, Pedro de Haro y Garcí Fernández Manrique. Nuño de Lara era potencialmente uno de los personajes más poderosos del reino, pero en 1352 era un niño de pocos años y murió en fechas muy próximas a la realización del Becerro. Los seis nobles restantes de este grupo son caballeros. Algunos de ellos, como Juan Martínez de Leiva, pueden considerarse además miembros de la alta nobleza por su proximidad al rey; el resto -Juan Rodríguez de Sandoval, Pedro Fernández de Velasco, Lope Díaz de Rojas, Pedro Ruíz Carrillo y Gómez carrillo- forman un grupo que puede calificarse como de nobleza regional castellana, cuya trayectoria puede seguirse en bastantes ocasiones desde finales del siglo XII o principios del XIII. Miembros de esas familias o grupos familiares participaban en la administración del reino con frecuencia y cada uno de ellos ejercía el poder de forma más intensa en sus propias zonas. Los individuos que he mencionado eran los cabezas de linaje a mediados del siglo XIV y concentraban la mayor parte de los derechos señoriales de sus respectivas familias, especialmente el señorío singular de las behetrías. Generalmente, sus parientes, hermanos, tíos o primos, tienen una proyección bastante menor, como veremos. La mayor parte de sus parientes también eran caballeros; por ejemplo, hasta 9 individuos apellidados Rojas fueron armados caballeros por el rey en la ceremonia de la coronación de Alfonso $\mathrm{XI}^{62}$. Pero el poder señorial de la mayoría de los restantes miembros de estos grupos familiares era mucho menor, formando parte del grupo de nobles de proyección local o comarcal. Los casos mejor conocidos, como el de Pedro Fernández y su padre Fernán Sánchez de Velasco, permiten saber que estos personajes emparentaron en ocasiones con ricos hombres y que integraron importantes patrimonios mediante enlaces matrimoniales.

\subsection{Señores de entre 10 y 19 lugares.}

A continuación de los nobles más poderosos puede establecerse un grupo de nobles con poder señorial entre 10 y 19 lugares. Este grupo estaría integrado por otros

61. Becerro, XV-101 y 102.

62. Crónica de Alfonso XI, pp. 235-236. 
9 nobles. Con más de 15 lugares encontramos a dos ricos hombres, Fernando Rodríguez de Villalobos y Ruy González de Castañeda.

Fernando Rodriguez de Villalobos ejercía derechos señoriales en 17 lugares, en 3 eran derechos de behetría y en 14 de solariego; pero sólo en una behetría y en dos solariegos era el único señor del lugar, en los 14 restantes lugares debía compartir sus derechos en diversas formas de condominio o señorío compartido. Es un altísimo grado de fragmentación de derechos que es común a otros casos que he mencionado. En la zona que he estudiado, los derechos de Fernando Rodríguez de Villalobos se concentraban en la zona norte de la merindad de Burgos con Ubierna (16 lugares), en torno a la zona denominada en el Becerro la bonor de Sedano, lo que expresa claramente la derivación de su patrimonio en la zona de los Manzanedo ${ }^{63}$. Fernando Rodríguez de Villalobos era hijo de otro Fernando Rodríguez y de Inés de la Cerda. Su padre había muerto poco antes de la realización del Becerro y esta fuente registra la mayor parte de los lugares en manos de su hijo, pero en 4 lugares aparece también su viuda Inés como co-señora junto a su hijo. Fernando Rodríguez de Villalobos no era el único Villalobos con importantes derechos señoriales en la zona, encontramos también a los hijos de Rodrigo Pérez de Villalobos, especialmente a Lope Rodríguez a quien me referiré más adelante. A mediados del siglo XIV, el parentesco entre Fernando Rodríguez y los hijos de Rodrigo Pérez era ya muy lejano.

Ruy González de Castañeda era señor de 15 lugares $^{64}: 6$ behetrías y 9 solariegos, pero sólo en uno de sus solariegos era señor único del lugar. Sus señorios en esta zona se centraban en las merindades de Villadiego ( 5 lugares) y Cerrato ( 9 lugares). Los 5 lugares que tenía Ruy González en Villadiego eran solariegos y en todos ellos aparece junto a él como co-señor Garcí Fernández Manrique; la misma combinación se da también en Ventosilla, el único lugar que posee Ruy González de Castañeda en la merìndad de Silos. En las villas de Villadiego, además, se ofrece el número de vasallos que tenía cada señor en cada lugar y la proporción es casi siempre de 4 vasallos del Manrique por 1 del Castañeda ${ }^{65}$. Todo ésto parece indicar el origen de los derechos de ambos nobles a partir de un bloque común y, probablemente, una relación de parentesco entre los dos. Además de los lugares en que era señor, Ruy González de Castañeda tenía en encomienda el lugar de Valbuena de Duero, de manos del monasterio de Valbuena, señor del lugar ${ }^{66}$. Ruy González no es el único Castañeda con derechos señoriales en la zona; Mayor de Castañeda, madre de Pedro Fernández de Velasco, era señora también de dos lugares, en uno compartía sus derechos con sus hijos Pedro y María y en otro con Lope Díaz de Rojas ${ }^{67}$. Sin embargo, Mayor de Castañeda y Ruy González

63. Sobre los señoríos de Fernando Rodríguez de Villalobos en la merindad de Burgos, véase I. ÁlVAREZ BORGE, El feudalismo castellano..., pp. 154-156 y 164.

64. He contabilizado como solariego suyo el lugar de Hontoria de Vertabillo en la merindad de Cerrato. De este lugar dice el Becerro que es solariego sin indicar quién es su señor, pero afirma que la martiniega del lugar la paga el concejo de Vertabillo; es muy probable que ambos lugares tuvieran el mismo señor y el de Vertabillo, que era behetría, era Ruy González de Castañeda; Becerro, I-41 y 44.

65. Becerro, XV-97 y VI-56, 57, 58, 59 y 64. En Villoba (VI-58) aparece también como señor Gutierre Fernández Delgadillo y en Barrio Panizares (VI-59) Alvar Díaz de sandoval.

66. Becerro, I-1. El Becerro registra el monasterio con su propio epígrafe, como si fuera un lugar independiente, y como tal lo he contado; Becerro, I-92.

67. Becerro, XI-100 y XV-71. 
pertenecían a ramas distintas del grupo familiar y no les unía una relación de parentesco próximo.

El rey y la reina también poseían el señorío de algunos lugares de la zona. La reina tenía 14 lugares, en uno de los cuales compartía derechos con otros señores. El número de lugares bajo la dependencia directa del rey es más difícil de establecer con precisión porque podían darse diversas situaciones. Los lugares de la reina se concentraban en la merindad de Cerrato ( 6 lugares) donde se encontraba el lugar de Palenzuela y sus aldeas dependientes, en el sector occidental de la merindad de Castrojeriz (4 lugares) donde estaban Astudillo y sus aldeas y en la merindad de Villadiego (4 lugares). Había 13 lugares que pueden considerarse bajo el señorío del rey; 8 de ellos formaban el bloque del Valle de Canales y las Cinco Villas en las zonas montañosas de la merindad de Silos lindantes con la Rioja ${ }^{68}$; el resto son lugares dispersos poco significativos excepto Castrojeriz, lugar donde, junto al rey, había otros señores ${ }^{69}$. Además de estos lugares había otros considerados realengos y cuyo señor, por tanto, era el rey en cierto sentido, pero en los que existían poderes señoriales intermedios. Así, el rey era señor de la ciudad de Burgos -que no figura en el Becerro- pero el concejo de Burgos era señor, a su vez, de varios lugares. Otro caso son varios lugares cedidos temporalmente por el rey a varios nobles y que contabilizaré en el lugar correspondiente a cada noble. Si descontamos las villas dependientes de los grandes concejos de realengo y los lugares cedidos a otros nobles, los señoríos directos del rey en la zona no parecen muy importantes, concentrándose en el Valle de Canales y las Cinco Villas. La reina, por su parte, controlaba algunas de las villas cabeceras comarcales de la zona y sus aldeas dependientes.

Tras el rey y la reina debemos contar a Alvar Rodríguez de Aza y a Juana Rodríguez de Torquemada, ambos señores de 13 lugares en esta zona. Alvar Rodriguez de Aza es, precisamente, uno de los nobles que disfrutaban el señorío de algunos lugares realengos por cesión regia; era señor de 11 behetrías y dos realengos. Los dos realengos son Villazopeque y Alleluengo en la merindad de Burgos pero dentro del sector integrado en la merindad que antiguamente pertenecía al alfoz de Belbimbre ${ }^{70}$. Sus 11 behetrías se extendian básicamente por la merindad de Cerrato ( 9 lugares) y en menor medida por la de Silos ( 2 lugares). Además disponía también de un lugar en encomienda del monasterio de Bujedo ${ }^{71}$. Era señor de varios lugares que tenían aldeas dependientes que, como he hecho en todos los casos, he contado individualmente, pero debe tenerse en cuanta que todas ellas eran aldeas yermas o despobladas en $1352^{72}$. Por lo tanto, su poder señorial real en la zona era menor. El apellido Aza está ligado a personajes que fueron considerados ricos hombres. Alvar Rodríguez aparece citado como tal en las crónicas en alguna ocasión ${ }^{73}$, aunque no era incluido como confirmante habitual de los privilegios regios. El hecho de disfrutar de villas realengas por cesión regia indica alguna forma de proximidad al monarca, pero no es en sí mismo sinónimo de rica hombría, poque en otros casos fueron caballeros de proyección

68. Becerro, XV-50, 51, 52, 53, 54, 55, 56 y 57.

69. Becerro, XI- 114.

70. Becerro, XIII-115 y 116.

71. Se trata de Báscones en la merindad de Silos; Becerro, XV-126

72. Becerro, I-19, 20, 21 y 28.

73. Crónica de Alfonso XI, p. 342. 
comarcal quienes las disfrutaron. En cualquier caso, Alvar Rodríguez de Aza era fundamentalmente un señor de behetrías, como otros destacados miembros de la nobleza regional castellana.

Juana Rodríguez de Torquemada es la mujer que, sin ser citada en referencia a ningún varón, esposo o padre, aparece con señoríos más extensos en la zona. Sin embargo, es una impresión que se debe matizar porque sus 13 solariegos son compartidos en un grado muy intenso. Era una de las señoras de Espeja de San Marcelino y sus 11 aldeas, en la merindad de Silos, pero, como he apuntado en varias ocasiones, el señorio de esos lugares era compartido por un total de 6 señores y, además, 5 de las aldeas de Espeja estaban yermas en $1352^{74}$. Fuera de ello, sólo era señora de otro solariego en la merindad de Cerrato, Hornillos de Cerrato, donde había un total de 7 señores $^{75}$. Por lo tanto, el poder señorial efectivo de Juana Rodríguez de Torquemada era mucho menor que el que transmiten las cifras.

Lope Rodriguez de Villalobos puede considerarse como señor de 12 lugares, aunque aquí también las cifras necesitan matizaciones. Lope Rodríguez era hijo del rico hombre Rodrigo Pérez de Villalobos, muerto antes de la realización del Becerro y cuya herencia permanecía parcialmente indivisa. Algunos de los lugares que tuvo Rodrigo Pérez aparecen en manos de sus tres hijos conjuntamente y, siguiendo el criterio usado en otros casos, los he atribuido al padre; se trata de cinco lugares. Sin embargo, otros lugares aparecen en manos de sus hijos individualmentes y estos casos los he atribuido a cada uno de ellos. El propio Becerro informa en varias ocasiones del nombre de los hijos de Rodrigo Pérez, que eran Lope Rodríguez, Fernando Ruíz y Garcí Fernández de Villalobos. Lope Rodríguez tuvo la preeminencia entre sus hermanos y el Becerro le atribuye individualmente el señonío sobre 12 lugares en esta zona, como he indicado, mientras que Fernando Ruíz es citado como señor individualmente de 2 lugares y Garcí Fernández en uno, mientras que los tres son citados conjuntamente en otros cinco lugares. Los 12 lugares de Lope Rodríguez corresponden a 9 behetrías, 2 solariegos únicos y un solariego compartido con su hermano Garcí Fernández y otro noble. Su poder señorial aparece bastante distribuido por el sector occidental de la merindad de Castrojeriz (4 lugares), la merindad de Muñó (4 lugares) y la de Burgos con Ubierna (3 lugares). Interesa resaltar que la mayor parte de los lugares donde Lope Rodríguez es citado individualmente como señor eran behetrías, porque en los lugares donde se menciona conjuntamente a los tres hermanos -bijos de..., en los lugares indivisos, sus derechos eran solariegos. Se trata de solariegos compartidos o condominios de abadengo y solariego compartido en cuatro de los cinco casos, todos ellos al norte de la merindad de Bur$\operatorname{gos}^{76}$. No es menos destacable que en esos 4 lugares los hijos de Rodrigo Pérez compartan derechos con su pariente lejano, Fernando Rodríguez de Villalobos, lo que indica que se trata de lugares sobre los que sus derechos se extienden desde bastantes décadas, remitiendo, con toda probabilidad al patrimonio de los Manzanedo. El quinto lugar de la herencia indivisa de Rodrigo Pérez es un caso un tanto especial. Se trata de Vilviestre de Muñó ${ }^{77}$, en la merindad de Muñó, lugar que en el Becerro se con-

\footnotetext{
74. Becerro, XV-73.

75. Becerro, $\mathrm{I}-56$.

76. Becerro, XIII-80, 91, 99 y 101

77. Becerro, XII-8
} 
sidera condominio de solariego y behetría; una calificación de ese tipo es muy poco frecuente -sólo existen 3 casos en los 684 lugares de las 6 merindades que he estudiado-, pero los señores del solariego eran los hijos de Rodrigo Pérez y la behetría era entre parientes de los Villalobos. La conclusión que se puede extraer al analizar los diferentes tipos de señorío de los lugares en manos de Lope Rodríguez y de los lugares indivisos de la herencia de su padre es que Lope Rodriguez había accedido al señorío singular de las behetrías de su padre, siendo el cabeza de linaje, el individuo preeminente entre sus hermanos, pero los solariegos permanecían sin dividir. La relación entre el señorio de las behetrías y la preeminencia que podemos denominar cabezas de linaje, tal y como ya he indicado páginas atrás, es bastante clara también en este caso. El padre, Rodrigo Pérez de Villalobos, todavía figura en privilegios de 1348; en conjunto, podemos atribuirle derechos señoriales sobre los 5 lugares de su herencia indivisa en 1352, más los 12 lugares en manos de su hijo Lope Rodríguez; probablemente también los dos lugares, ambos behetrías, en que figura como señor su otro hijo, Fernando Ruiz de Villalobos, aunque esto último me plantea algunas dudas ${ }^{78}$. Así pues, Rodrigo Pérez había sido señor entre 17 y 19 lugares de esta zona aproximadamente.

Ruy Fernández de Tobar también había muerto ya en 1352; el Becerro registra sus señoríos en manos de sus hijos; en algún lugar indica que eran 4 pero desconozco sus nombres excepto el uno de ellos, Fernán Sánchez de Tobar. Los señoríos en manos de los bijos de Ruy Fernández de Tobar que, como en otras ocasiones, atribuyo al padre, se extendían por 12 lugares. Por su parte, Fernán Sánchez es citado como señor de otros 3 lugares. Ruy Fernández de Tobar había sido un caballero, cabeza de linaje, con una proyección regional sólida, similar a otros que he mencionado, y como ellos era, fundamentalmente, señor de behetrías. Sus 12 lugares en esta zona eran behetrías, compartiendo derechos como señor en dos de ellas, y se extendían básicamente por la merindad de Villadiego $(7$ lugares) y el sector occidental de la de Castrojeriz (4 lugares). Los tres lugares que aparecen en manos de su hijo Fernán Sánchez también eran behetrias y estaban todas ellas en el sector occidental de la merindad de Castrojeriz. En este caso, daría la impresión de que el señorio de las behetrias había pasado sólo en algunos casos a manos de uno de los hijos, el próximo cabeza de linaje, mientras que en otros casos permanecía indiviso entre los herederos. Es posible que fuera así, pero no dejaría de ser sorprendente. Cabe apuntar otra hipótesis: las behetrias todavía indivisas serían las de la herencia paterna estrictamente, mientras que las de Fernando Sánchez procederían de adquisiciones propias, por matrimonio o compra. Una base que permite plantear esta hipótesis es que en las behetrías de los bijos de Ruy Fernández de Tobar se dice, además, que son sus naturales, es decir que todos ellos son diviseros en el lugar; sin embargo, en las 3 behetrías de Fernán Sánchez no se menciona a sus hermanos como diviseros. Retomando ahora el ejemplo anterior, de Lope Rodríguez de Villalobos, en todas las behetrías cuyo señorio había recibido figuran

78. Becerro, XIII-66 y VI-22. He descartado la posibilidad de una confusión de Fernando Ruíz con su pariente lejano Fernando Rodriguez -poderoso sex̃or en esas mismas zonas- porque en el texto del Becerro que ha llegado a nosotros sus apellidos son consistentemente Ruiz y Rodríguez, respectivamente. Aun así, siempre hay que considerat posibles errores en el Becerro. Por otra parte, el otro hermano, Garcí Fernández de Villalbos, según he apuntado sólo es señor de un solariego compartido en el que también aparece su hermano Lope Rodríguez; por lo tanto, no me parece problemático atribuir este lugar a su padre. 
también como sus hermanos como diviseros, bien con la expresión bijos de Rodrigo Pérez de Villalobos o bajo la fórmula entre parientes.

Cerrando el grupo de señores que poseen derechos de señorío entre 10 y 19 lugares figura Diego Pérez Sarmiento, señor en 11 solariegos, todos ellos compartidos y todos en la merindad de Silos, menos uno en el sector oriental de la de Castrojeriz. Como he indicado, estaba casado con María de Velasco, hermana de Pedro Fernández de Velasco, y su presencia en la zona corresponde a los derechos adquiridos por su matrimonio con María, procedentes de Fernán Sánchez de Velasco. De hecho, en algunos lugares se le cita como señor por su mujer, pero en la mayoría de los casos quien es citada directamente como señora es su esposa, añadiendo después mujer de.... En correspondencia con el origen de sus derechos, Diego Pérez Sarmiento coincide como co-señor en esta zona con Pedro Fernández de Velasco en todos sus lugares.

Exceptuando al rey y la reina, en el grupo de señores cuyo poder se extendía entre 10 y 19 lugares aparecen tanto ricos hombres y miembros de la alta nobleza como caballeros miembros de la nobleza regional castellana. Entre los primeros están los dos Villalobos, Fernando y Lope Rodríguez, parientes sólo lejanos, Alvar Rodríguez de Aza y Ruy González de Castañeda. En el grupo de los caballeros de proyección regional puede incluirse a Ruy Fernández de Tobar. La presencia de Juana Rodríguez de Torquemada y de Diego Pérez Sarmiento obedece a situaciones específicas en cada caso.

\subsection{Señores de entre 3 y 9 lugares}

El grupo de nobles con poder señorial entre 3 y 9 lugares está integrado por 25 personajes, descontadas las menciones a Fernando Rodríguez de Villalobos, el esposo de Inés de la Cerda, y a Rodrigo Pérez de Villalobos en los casos en que aparecen citados sus tres hijos conjuntamente; ya me he referido a ambos casos en las páginas anteriores. Entre los restantes señores podemos distinguir diversas situaciones. También aquí encontramos un cierto número de ricos hombres -todos ellos en el grupo más destacado de señores de entre 5 y 9 lugares-, pero son siempre personajes que centran el grueso de su poder en otras zonas del reino. Otro gupo que podemos distinguir es el de los caballeros de proyección comarcal; los límites entre ellos y los que denomino caballeros regionales no son fáciles de establecer. Un tercer grupo estaría formado por individuos secundarios de grupos familiares cuyos cabezas de linaje tenían proyección regional; a diferencia de sus parientes más poderosos, encontraremos aquí a caballeros de proyección comarcal, como los anteriores, pero que portan apellidos como Velasco, Sandoval, Carrillo, etc. Por último, encontraremos también algunas situaciones específicas. Obviamente, la clasificación que propongo no es cerrada en absoluto; las diferencias entre los personajes que incluyo en el segundo y en el tercer grupo podían ser inexistentes en la realidad y la adscripción de algunos personajes a los diversos grupos son difíciles de establecer como veremos. Sin embargo, creo que una división como la que propongo puede facilitar el análisis.

Entre los ricos hombres figuran Ramir Flórez de Guzmán, Sancha viuda de Diego López de Haro y Martín Gil de Alburquerque. Quizás no rico hombre pero sí miembro de la alta nobleza era también Juan Díaz de Rocaful.

Ramír Flórez de Guzmán era un rico hombre cuyo patrimonio, siendo de procedencia castellana, a mediados del siglo XIV se centraba ya probablemente en el rei- 
no de León, donde su abuelo, Juan Pérez de Guzmán, había adquirido mediante enlace matrimonial propiedades y derechos procedentes de los Froílaz. El individuo más destacado de esta rama del gran grupo familiar de los Guzmán parece ser en esos momentos su hermano Pedro Núñez de Guzmán pero, sin embargo, no parece que Pedro Núñez conservara señoríos importantes en Castilla. Ramír Flórez era señor de 9 lugares, 5 behetrías y 4 solariegos. Era señor de la behetría de Guzmán en la merindad de Cerrato, lugar que daba nombre al grupo familiar, y el resto de sus villas estaban en la merindad de Silos. En 4 de sus 9 lugares, 1 behetría y 3 solariegos, Ramír Flórez debía compartir sus derechos con otros nobles.

Juan Díaz de Rocaful no aparece en las nóminas de ricos hombres castellanos pero, con toda probabilidad, se le puede considerar un miembro de la alta nobleza. Los Rocaful eran de procedencia aragonesa y tuvieron una proyección muy clara en Murcia, donde Guillén de Rocaful obtuvo bienes importantes ${ }^{79}$. Desconozco si después conservaron intereses patrimoniales en Aragón, pero sí los aumentaron en Castilla. La proyección señorial de Juan Díaz en esta zona se concreta en una behetría y 6 solariegos, todos ellos compartidos. La behetría corresponde al lugar de Santa María de Añuéquez, en la merindad de Silos, donde Juan Díaz comparte derechos con doña Sancha, la viuda de Diego López de Haro. Sobre este lugar el Becerro da algún otro dato que permite avanzar hipótesis sobre el orígen de los derechos del de Rocaful en esta zona ${ }^{80}$. El Becerro indica que este logar era bebetria e despues comprolo Diego Lopez de Haro e despues que finara el dicho Lopez que fincara en estos (doña Sancha y Juan Díaz).Así pues, sus derechos proceden de los de Diego López de Haro y del texto puede desprenderse que se trata de derechos de herencia. Doña Sancha aparece como señora en 6 lugares y en todos ellos comparte sus derechos de señorío con Juan Díaz de Rocaful. La relación entre ambos es clara. Más arriba he indicado que, probablemente, Diego López de Haro, esposo de Sancha, fue el padre de don Pedro de Haro; si esa relación es cierta, habría una relación de parentesco próximo entre Pedro de Haro y Juan Díaz de Rocaful, aunque el Becerro no recoge la relación concreta entre ambos. Sea como fuere, el poder señorial de Juan Díaz de Rocaful es esta zona es prácticamente idéntico al de Sancha.

Martín Gil, hijo de Juan Alfonso de Alburquerque, era señor de 6 lugares, todos ellos behetrías, localizados en su mayoría en la zona occidental de la merindad de Castrojeriz. Entre ellos está Melgar de Fernamental y sus lugares dependientes, ya despoblados $^{81}$, donde Martín Gil compartía el señorío singular con Pedro de Haro. Su padre Juan Alfonso tenía una proyección señorial muy importante en las zonas de Tierra de Campos $^{82}$, donde disfrutaba de los señoríos de los Meneses adquiridos mediante matrimonio. Sin embargo, el Becerro no menciona derechos de Juan Alfonso de Alburquerque en las merindades que estudio aquí, sino de su hijo. Desconozco porqué se da esa situación, sin duda llamativa. Es posible que los señoríos de Martín Gil no procedan directamente de su padre o que se produjera una asignación de derechos a su favor aún en vida de su padre. La primera posibilidad se vería reforzada por el hecho de que los señoríos de Martín Gil se extienden por zonas donde no parece que hubiera una

79. J.TORRES FONTES, El señorío de Abanilla, Murcia, 1982, especialmente pp. 23-51.

80. Becerro, XV-120.

81. Becerro, XI-58.

82. P. FERNÁNDEZ MARTÍN, "El último señor de las behetrías...". 
presencia anterior fuerte de los Meneses y, sobre todo, porque en alguno de sus lugares el Becerro indica que el señor anterior del lugar era Juan Núñez de Lara ${ }^{83}$. Por otra parte, a juzgar por el valor de las martiniegas que pagan sus lugares, se trata de villas de una cierta relevancia, incluso antiguos centros territoriales como Melgar ${ }^{84}$. Cabe la hipótesis de que los señoríos que disfruta Martín Gil en 1352 le hubieran sido asignados directamente por el rey muy poco antes de la redacción del Becerro, inmediatamente después de la muerte de Juan Núñez de Lara, que sería su señor anterior, beneficiándose de la minoría de edad de don Nuño de Lara.

El segundo grupo de nobles que puede hacerse, dentro del nivel de señoríos entre 3 y 9 villas, está ocupado por caballeros con una proyección comarcal. En general, pertenecen a un escalón claramente inferior al de los Juan Rodríguez de Sandoval, Pedro Fernández de Velasco, Lope Díaz de Rojas, etc. que se incluían en el grupo de nobles más poderosos. Entre ellos están Diego García de Padilla y su tío Juan Fernández de Hinestrosa.Ambos, sobre todo el segundo, alcanzarán una gran proyección en el reino poco después de la redacción del Becerro, en tanto que miembros del círculo de parientes de María de Padilla, la amante de Pedro I, hermana de Diego García de Padilla. Pero, antes de eso, probablemente ambos pueden considerarse miembros del grupo de caballeros con una proyección de tipo comarcal en la zona de Castrojeriz. Diego García de Padilla parece algo más poderoso que su tío a juzgar por sus señoríos; era señor de 7 lugares, en 3 con derechos de behetría y en 4 con derechos de solariego, compartiendo sus derechos con otros señores en 4 de sus lugares. Sus derechos se concentran en el sector occidental de la merindad de Castrojeriz ( 5 lugares) y en villas próximas pero integradas en la merindad de Cerrato (2 lugares). Diego García compartía sus derechos de señorío con sus parientes en varios lugares, con su tío Juan Fernández de Hinestrosa en una ocasión y en otra con su hermana María Díaz y su madre María González ${ }^{85}$. Es posible que Diego García y su familia estuvieran relacionados con el maestre de la orden de Calatrava de principios del siglo XIV, García López de Padilla, pero lo desconozco. La familia de Diego García no eran los únicos Padilla con proyección señorial en la zona; García González y Pedro López de Padilla tuvieron también algunos señoríos, como indicaré más adelante, pero no creo que hubiera una relación de parentesco cercano entre ellos y la familia de Diego García.

Juan Fernández de Hinestrosa era señor en 2 solariegos y 3 behetrías, todas ellas en la zona de Castrojeriz, y compartía derechos con otros nobles en 3 de sus 5 lugares, en uno de ellos con su sobrino, según he indicado, y en otro con su hermano Martín González de Hinestrosa. Este último lugar es la behetría de Pedrosa del Prínci$\mathrm{pe}^{86} \mathrm{y}$ es el único lugar en que poseía derechos señoriales su hermano Martín González. La proyección tanto de los Padilla como de los Hinestrosa en la zona de

83. Becerro, XI-1.

84. La martiniega de Villasilos eran 900 maravedís, la de Melgar y Quintanilla, Requejo y Velilla -los 3 lugares que pagan la martiniega con Melgar- 690 maravedís, y la de Santa María del Campo 502; Becerro, XI-1, XI-58 y XII-25. Fuera de las merindades que estudio aquí, Martín Gil sólo era señor de otra behetría también importante; se trata de Boadilla de Rioseco en la merindad de Carrión cuya martiniega era de 800 maravedís; Becerro, V-92.

85. Becerro, XI-82 y 79 , respectivamente.

86. Becerro, XI-2. 
Castrojeriz, donde se encuentran los lugares cuyos nombres adoptaron como apellidos toponímicos, puede rastrearse desde el siglo XIII.

Gutierre Fernández Delgadillo era señor de 7 lugares, 4 behetrías y 3 solariegos compartidos con otros señores. El núcleo de su poder estaba en la merindad de Villadiego ( 6 lugares) y en zonas próximas de la merindad de Burgos. Por su poder señorial y el tipo de sus señoríos parece un caso muy similar al de los Padilla o Hinestrosa mencionados. También a él habría que considerarle un caballero con proyección comarcal.

Estos caballeros concentraban su poder señorial en zonas concretas, en villas casi siempre próximas entre sí. Garcí González de Villaute ejercía el señorío en 5 lugares de la zona norte de la merindad de Burgos. Sus derechos son siempre de solariego y en 4 de sus 5 lugares compartía sus derechos con otros señores. Dos de los lugares donde disfrutaba de derechos señoriales estaban vinculados a la bonor de Sedano ${ }^{87}$, mientras que en tres de sus lugares compartía derechos con Fernando Rodríguez de Villalobos y en otro con la orden de Santiago. Debe existir una relación entre esos hechos aunque la desconozco con exactitud ${ }^{88}$.

Ochoa Martínez de Avellaneda tuvo también proyección señorial sobre un grupo compacto de 5 villas de la merindad de Silos. Se trata de Tejada y de Fuentearmejil y sus 3 aldeas. Sus derechos son siempre de solariego. En 1352, Ochoa Martínez ya había muerto y quienes figuran en el Becerro son sus hijos, cuyos nombres y número desconozco. Sus hijos disfrutaban de un patrimonio señorial indiviso como los otros casos que he mencionado. Todos los lugares de Ochoa Martínez de Avellaneda presentan un alto grado de fragmentación señorial; en Fuentearmejil y sus aldeas compartía derechos con otros 3 señores y en Tejada con 2 . Este personaje y su familia no resultan bien conocidos porque las zonas nucleares de su dominio, el sureste de la merindad de Silos, están mal documentadas en general. Probablemente estaban relacionados con la familia de fundadores y patronos del monasterio de Fuencaliente, monasterio también poco conocido ${ }^{89}$. Ochoa Martínez de Avellaneda debía ser pariente de Juan Martínez de Avellaneda, aunque desconozco la relación exacta entre ambos. Este último también había muerto en 1352 y su patrimonio señorial aparece igualmente en manos de sus hijos como herencia indivisa; tampoco en este caso se menciona el nombre ni el número de hijos. Juan Martínez de Avellaneda fue señór de dos condominios de abadengo y solariego compartido en zonas cercanas a las de su probable pariente. En ambos lugares compartía derechos con el monasterio de Fuencaliente, que también era señor en 4 de las 5 villas de Ochoa Martínez.

Pedro García de Grijalba y su hermano Gómez Gutiérrez de Grijalba o de Herrera, ambos, disponían de derechos señoriales en 5 lugares. Coincidían como coseñores en 4 lugares, bien ellos solos bien con otros señores. Sus derechos correspondían básicamente al señorío superior de behetrías y en un caso ejercían derechos de solariego compartido en condominio con abadengo. Sus villas se encontraban en la merindad de Villadiego y en el sector occidental de la de Castrojeriz, aunque Gómez

87. Becerro, XIII-94 y 106.

88. I. ÁLVAREZ, El feudalismo castellano..., pp. 98-100 y 156-157.

89. I. ÁLVAREZ, Estructura social y organización territorial en Castilla la Vieja meridional. Los territorios entre el Arlanzón y el Duero en los siglos X al XIV,Tesis Doctoral, Universidad de León, 1991 , pp. 631-633 y $1220-1222$. 
Gutiérrez disponía de derechos en una villa más alejada en la merindad de Silos ${ }^{90}$. La identificación de Gómez Gutiérrez de Grijalba y de Gómez Gutiérrez de Herrera me parece clara, no siendo el único individuo que aparece citado indistintamente con los dos apellidos toponímicos ${ }^{91}$. El hecho de que ambos hermanos compartan derechos en 4 de sus 5 lugares, respectivamente, remite a su herencia común. No se trata de una herencia indivisa, como hemos visto en otros casos reflejada con la expresión bijos de..., sino de una herencia dividida en partes iguales, división que en este caso afectó también al señorío singular de las behetrías, que ambos hermanos compartían en una situación que no era muy frecuente ${ }^{92}$.

Ruy Gutiérrez de Quijada fue señor de 4 lugares en la zona que estudio, 3 en la merindad de Villadiego y uno en el sector occidental de la de Castrojeriz; además, era señor de otro lugar en la merindad de Monzón. Ya había muerto en 1352 y sus derechos quedaron consignados en el Becerro como herecia indivisa en manos de sus hijos. En un lugar el Becerro indica quienes eran sus herederos, sus dos hijas, Constanza Rodríguez y Mari Rodríguez, la esposa de Fernando García Duque ${ }^{93}$. Los derechos de Ruy Gutiérrez eran siempre de solariego; en 3 de sus 4 lugares compartía sus derechos con otro señor y en dos de ellos con Martín Alfonso de Arenillas ${ }^{94}$, lo que podría indicar una relación de parentesco. Ruy Gutiérrez de Quiijada parece el individuo más importante de la familia Quijada, sería el cabeza de linaje, aunque su poder no se basaba tanto en señoríos de behetría como de solariego

Dentro de este grupo de nobles podemos incluir también a Garcí Fernāndez de Villagutiérrez que también figura entre los señores con derechos sobre tres lugares, todos ellos en la merindad de Muñó. Había muerto ya en 1352 y sus derechos aparecen en manos de sus hijos, cuyos nombre y número no se mencionan. Garcí Fernández de Villagutiérrez disponía de derechos solariegos en dos lugares, compartiendolos en uno de ellos con otros tres nobles, y de derechos de behetría en un lugar, pero en condominio con abadengo. Es probable que este personaje y sus hijos no fueran caballeros sino escuderos y su proyección señorial se situaba entre el ámbito local y el comarcal.

90. El parentesco entre ambos en Crónica de Alfonso XI, p. 236, en el pasaje de la coronación del rey donde ambos fueron armados caballeros. Atribuyo a Pedro García el co-señorío de la behetría de Citores del Páramo, donde no se menciona su apellido toponímico, pero que tiene una situación señorial muy parecida al lugar cercano de Pérex donde sí se indica su apellido completo; Becerro, XI-46 y 47.

91. Por lo que se refiere a sus derechos señoriales en esta zona, como Gómez Gutiérrez de Ferroia se le cita en Becerro, Xl-46; sin apellido toponímico en XI-46; y como Gómez Gutiérrez de Grijalba en VI-83 y 95 y en XV-79. En calidad de divisero, no de señor, aparece con el apellido Herrera en XI-3 y con el de Grijalba en VI-53, por ejemplo.

92. Además de las behetrías de Pérex y Citores, que ya he mencionado, ambos compartían derechos en el condominio de solariego y behetría compartida de Mahallos (Becerro, VI-83) donde los dos hermanos eran señores de la behetría y otro Grijalba del solariego; y en el condominio de abadengo y solariego compartido de Puentes de Amaya (VI-95), donde compartían derechos con Garcí Laso y el monasterio de San Andrés e Arroyo. Por otro lado, en èl propio lugar de Grijalba (XI-52) -lugar donde el Becerro no indica quién era el señor- se señala que Gómez Gutiérrez y un Pedro Gutiérrez eran hermanos e hijos de Garcí Pérez de Grijalba; no me parece descartable que hubiera habido un error equivocando el apellido de Pedro García por Gutiérrez.

93. Becerro, XI-69. Podría interpretarse que su herencia se hubiera tepartido en ese lugar y no en los otros pero no me parece probable.

94. Becerro, VI-73 y 76. 
Garcí Fernández de Villagutiérrez puede incluirse dentro de este grupo entendiendo la clasificación con un sentido abierto e instrumental. Es un ejemplo del caracter abierto de esta clasificación por abajo, no hay un límite totalmente preciso entre la proyección comarcal y la puramente local. De manera similar, tampoco hay un límite preciso que señale qué grado de extensión del poder señorial corresponde a un ámbito comarcal y al ámbito regional. Un ejemplo de ello lo representan Gonzalo González de Lucio y Juan Rodríguez de Villegas, que eran hermanos aunque llevaron apellidos toponímicos diferentes. En la zona que estudio, los señoríos de ambos se refieren a 3 lugares cada uno; ambos disponían de derechos sobre 2 lugares en el sector occidental de la merindad de Castrojeriz y de uno en la de Villadiego. Gonzalo González de Lucio era señor de una behetría, y compartía también el señorío de otra behetría y de un solariego. Los tres lugares de Juan Rodríguez de Villegas tenían una composición similar, dos behetrías compartidas y un solariego compartido. A juzgar por esos datos, ambos podrían ser considerados caaballeros de ámbito comarcal reducido. Pero, en este caso, esos datos son insuficientes para valorar la situación de estos personajes. Primero, porque tanto uno como otro disponían de señorío en un número considerable de villas en zonas fuera del ámbito de este estudio, en la merindad de Aguilar de Campoo, al norte de la de Villadiego. Y, segundo, porque los dos figuran como diviseros en un buen número de behetrías de la merindad de Villadiego en las que no se especifica el nombre del señor; es probable que en algunas de ellas dispusieran de derechos de señorío singular. Al menos eso debemos considerar por lo que se refiere a Gonzalo González de Lucio y las villas de Valdelucio ${ }^{95}$. Teniendo esto en cuenta, Gonzalo González de Lucio aparece como más poderoso que su hermano, próximo a los caballeros de la nobleza regional que he mencionado. El hecho de que no lleve el apellido toponímico de Villegas hace que, por otra parte, haya que considerar que su preeminencia puede no provenir de tratarse de cabeza de linaje, heredero del señorío de las behetrías de los Villegas. Sería necesario un estudio en detalle de esta familia o grupo familiar para avanzar más en la explicación.

El tercer grupo de nobles que puede establecerse entre los señores que poseían derechos extendidos por entre 3 y 9 lugares, corresponde a personajes que llevan apellidos como Velasco, Sandoval, Carrillo, Leiva o Rojas. Los cabezas de linaje de esos grupos familiares los hemos visto disponiendo de señoríos mucho más amplios; eran los miembros de lo que he denominado nobleza regional castellana, algunos de los cuales pueden considerarse miembros de la alta nobleza por su proximidad al rey y por su papel político; algunos de ellos alcanzaron la rica hombría. Sin embargo, ahora lo que nos encontramos son otros miembros de los grupos familiares que se identifican con esos apellidos, los individuos secundarios, los que no eran cabezas de linaje, o los que quizás tuvieran un papel equivalente a los cabezas de linaje de las ramas menos destacadas de esos grupos familiares. La falta de datos sobre las relaciones de parentesco, la inexistencia de estudios detallados, nos impedira en muchos casos saber la relación exacta de estos nobles y sus probables parientes mucho más poderosos.

Enlazando con los problemas de clasificación que he mencionado líneas más arriba podemos empezar considerando el caso de Pedro Ruiz Villegas. En la zona que estudio, Gonzalo González de Lucio y Juan Rodríguez de Villegas no aparecen como

95. Becerro, VI-1 y ss. 
los únicos miembros de esta familia o grupo familiar. Los Villegas tienen una clara proyección en la zona desde, al menos, principios del siglo XIII. Pedro Ruiz de Villegas disponía del señorío sobre 4 lugares, 3 behetrías en el sector occidental de la merindad de Castrojeriz y un solariego compartido en la merindad de Burgos. A diferencia de Gonzalo González de Lucio y de Juan Rodríguez de Villegas, Pedro Ruiz sí puede ser considerado un caballero comarcal por su proyección señorial, puesto que estos lugares forman el grueso de su dominio señorial y sólo contaba con el señorío de otro lugar fuera de estas zonas ${ }^{96}$. Pero Pedro Ruiz Villegas era también un personaje más destacado en la zona de lo que indica su proyección señorial. En este caso, se refleja en el hecho de que disfrutara de rentas por concesión regia en otros 8 lugares de la merindad de Villadiego y en uno más de la de Asturias de Santillana ${ }^{97}$. El disfrute de esas rentas habla de su posición política destacada.

Como en otros casos, el Becerro no ofrece datos sobre la relación de parentesco que pudiera haber entre Pedro Ruiz Villegas y los hermanos Juan Rodríguez de Villegas y Gonzalo González de Lucio. No descarto que no hubiera entre ellos una relación de parentesco próximo. También desconozco la relación de parentesco de esos tres personajes con los otros Villegas que disfrutaban de derechos señoriales en la zona y que tenían una proyección claramente menor: Sancho Ruiz de Villegas, señor en dos lugares; Juan Rodríguez, hijo de Lope Ruiz de Villegas, también señor en dos lugares; y Alfonso López, hijo de Sancho Ruiz de Villegas, señor en un lugar. La presencia como señores de estos nobles se debe a dos casos concretos que presentan una situación específica: Pedrosa de Páramo y el propio lugar de Villegas ${ }^{98}$. Ambos lugares eran behetrías en las que no había un único señor singular, sino que puede interpretarse que todos los Villegas -o casi todos- eran los señores, además de ser diviseros o naturales. Estos dos casos son una muestra de las dificultades de interpretación del Becerro en determindas ocasiones. En Pedrosa, además de los Villegas como señores-diviseros, había otros diviseros como Nuño de Lara, Pedro de Haro, don Tello, Ruy González de Castañeda, Garcí Fernández Manrique, etc.; es decir, había unos señores-diviseros, los Villegas, y otra lista de diviseros normal. En la villa de Villegas sólo figuran los Villegas como señores y como diviseros. El resultado son behetrías que en un caso tenían 6 señores y en otro $5^{99}$. Otro problema viene determinado por la identificación de los personajes debido a la homonimia. Había dos individuos, al menos, llamados Juan Rodríguez miembros del mismo grupo familiar o que llevaban el mismo apellido toponímico. Uno de ellos era un noble más destacado junto a su hermano Gonzalo González de Lucio. El otro probablemente era el mismo que en ocasiones aparece como Juan Rodríguez Pan y Agua quien, a su vez, también tenía un hermano llamado Gonzalo González. Había, pues, al menos, dos Juan Rodríguez, uno de Villegas y otro Pan y Agua, hermanos de otros dos Gonzalo González, uno de Lucio (hermano del primero) y otro de Villegas o Pan y Agua (hermano del segundo). La homonimia hizo que algunos miembros del grupo familiar

96. El condominio de abadengo y solariego compartido de Manquillas en la merindad de Monzón; Becerro, III-13.

97. Becerro, VI-26, 29, 32, 34, 37, 44, 45 y $84 ; \mathrm{y}$ X-106

98. Becerro, XI-25 y 43 respectivamente.

99. Un caso muy similar a las behetrías entre parientes en las que no se especifica el señor singular, como Villamorón, también de los Villegas, que en este caso no he contabilizado como behetrías de señorío múltiple sino como behetría sin señor singular; Becerro, XI-44. Sin embargo, la situación de hecho de unos y otros lugares debía ser muy similar. 
adoptaran apellidos diferentes para facilitar su identificación. Es algo que sucede en otros grupos familiares donde algunos individuos tienen apodos que terminan convirtiendose en apellidos de su rama del grupo familiar. Eso sucede también, por ejemplo, con los Sandoval Rostros de Puerco. La proyección señorial de estos personajes es básicamente sobre behetrías colectivas.

Juan Sánchez de Velasco y Alvar Díaz de Sandoval disponían de derechos señoriales en 6 y en 5 lugares respectivamente. Sus señoríos se extendían por zonas distintas, por la merindad de Silos los del primero y por la de Villadiego los del segundo; pero entre ellos pueden trazarse algunos paralelismos interesantes. Ambos eran caballeros y ambos compartían sus apellidos con otros caballeros mucho más poderosos que ellos. Las 6 villas de Juan Sánchez de Velasco en esta zona corresponden a un grupo de solariegos compartidos en el norte de la merindad de Silos. Se trata de un bloque homogéneo de lugares próximos entre sí y sus señores debieron obtener sus derechos de una herencia común ${ }^{100}$. Los señores que acompañan a Juan Sánchez de Velasco en esos lugares son Pedro Fernández de Velasco y su hermana doña María, Gómez Carrillo y Juan Martínez de Leiva; los derechos de estos últimos, ya muertos, aparecen en 1352 en manos de sus hijos como herencias indivisas. Hay ligeras variaciones en la nómina de señores que podrían deberse a errores en la redacción o en la transmisión del Becerro. Uno de esos posibles errores afectaría al propio Juan Sánchez de Velasco, que no es citado en otro lugar cercano donde aparece la misma combinación de señores ${ }^{101}$. La interpretación más probable es que todos estos señores hubieran obtenido sus derechos en estos lugares a partir de una herencia común. Desconozco con exactitud la relación de Juan Sanchez con Pedro Fernández y María de Velasco. Es posible que el primero fuera hermano de Fernán Sánchez de Velasco y, por lo tanto, tío de Pedro Fernández y María, siguiendo una de las posibles interpretaciones de la información que proporciona el Libro de Linajes del conde don Pedro, aunque tampoco es descartable que pertenezcan a ramas de los Velasco separadas tiempo atrás y con individuos homónimos en ellas ${ }^{102}$. Si esa interpretación a partir del Libro de Linajes fuera cierta, los derechos de todos los Velasco en la zona procederían, al menos, de Sancho Sánchez de Velasco o, más probablemente, de la esposa de éste, Sancha García Carrillo ${ }^{103}$, lo que explicaría la presencia también de Gómez Carrillo. Habría que pensar que Juan Martínez de Leiva también estaba unido por relaciones de parentesco con los anteriores. Sea como fuere, el poder señorial de Juan Sánchez de Velasco en esta zona debe matizarse por el carácter fuertemente compartido de sus señoríos.

Alvar Díaz de Sandoval era señor de 4 behetrías y un solariego y también compartía sus derechos de señorío en 3 de sus 5 lugares. Como sucedía con Juan Sánchez de Velasco respecto a Pedro Fernández de Velasco, tampoco conozco la relación de Alvar Díaz de Sandoval con Juan Rodríguez de Sandoval, personaje mucho más poderoso que él. Los Sandoval, según ya he apuntado, parecen un grupo familiar muy

100. Becerro, XV-43, 44, 45, 47, 48 y 49.

101. Becerro, XV-46.

102. J. MATTOSO (ed. ), Livro de Linbagens do Conde don Pedro, Lisboa, 1980, vol. I, pp. 351-352; y E. GONZÁLEZ CRESPO, Elevación de un linaje..., pp. 19.

103. E. GONZÁLEZ, Elevación de un linaje..., pp. 31. Sin embargo, el Libro de Linajes dice que la madre de Juan y Fernán Sánchez de Velasco fue Guimar Fernández de Castro; Livro de Linbagens, pp. 351-352. 
amplio con diversas ramas a mediados del siglo XIV. En 1352 Alvar Díaz ya había muerto y sus derechos aparecen en manos de sus hijos como herencia indivisa. El Becerro indica en ocasiones el número de sus hijos, pero a veces se da la cifra de 4 y otras veces la de $\boldsymbol{6}^{104}$; también aparece en ocasiones el nombre de alguno de ellos pero, a pesar de los problemas de hominimia que dentro de este grupo familiar es muy abundante, no creo que ninguno de los hijos de Alvar Díaz tuviera ningún señorío individualmente. En dos de sus behetrías Alvar Díaz compartía el señorío singular con su hipotético pariente mucho más poderoso, Juan Rodríguez de Sandoval; no deja de ser significativo ese hecho y que una de esas behetrías fuera Sandoval de la Reina, el lugar cuyo topónimo habían adoptado como apellido ${ }^{105}$.

Juan Alfonso Carrillo era señor de 4 behetrías, 3 en la merindad de Muñó y una en la de Silos. Ya he mencionado a otros Carrillo mucho más poderosos, Pedro Ruiz Carrillo y Gómez Carrillo; desconozco la relación entre ellos y Juan Alfonso Carrillo. La situación de Juan Martínez de Rojas y Sancho Ruiz de Rojas era similar; ambos eran menos poderosos que el personaje más destacado de entre los muchos que se llevaban el apellido de Rojas. El parentesco de Juan Martínez y Sancho Ruiz con Lope Díaz, si existía, seguramente era muy lejano.Aunque en las zonas que estudio Juan Martínez y Sancho Ruiz eran señores de 3 lugares cada uno, entre ambos existían algunas diferencias. Juan Martínez de Rojas era señor de 3 behetrías, las tres en la merindad de Burgos, próximas a una de las zonas nucleares de los dominios de los Rojas como era La Bureba. Sancho Ruiz de Rojas era señor de una behetría, Cabia en la merindad de Burgos, y de un condominio de abadengo y solariego compartido y de otro solariego compartido en la merindad de Cerrato. Además, fuera de las zonas que estudio aquí, podía ejercer el señorío en otros 5 lugares más, 4 de ellos en la merindad de Monzón. Es claro, por lo tanto, por un lado, que era más poderoso -juzgando a partir del número de lugares donde podía ejercer derechos señoriales- que Juan Martínez; y, por otro lado, que sus señorios se extendían por zonas no nucleares de los Rojas, las merindades de Monzón y Cerrato. Por otra parte, los dos lugares donde Sancho Ruiz tenía derechos en la merindad de Cerrato tenían una estructura señorial muy fragmentada, lo que indicaría una situación previa de behetría ${ }^{106}$.

Sancho Martinez de Leiva era señor de 4 lugares, 3 en la merindad de Silos y uno en el sector oriental de la de Castrojeriz ${ }^{107}$. Sus señoríos consistían en una behetría, un solariego compartido y dos condominios de abadengo y solariego compartido. Los lugares donde disponía de derechos de solariego también tenían un señorío muy fragmentado, lo que remitiría, igualmente, a situaciones previas de behetría. Probablemente Sancho Martínez era hermano de Juan Martínez de Leiva pero su proyección señorial era mucho menor, aunque es probable que ambos tuvieran el grueso de su patrimonio en zonas no registradas en el Becerro de las Bebetrías.

104. Becerro, XI-49 da 6 hijos y XI-54 da 4 .

105. Becerro, VI-31.

106. Hornillos de Cerrato contaba con un total de 7 señores y Villafuerte de Esgueva con 5 ; Becerro, I-56 y 2 respectivamente. La misma circunstancia es extensible a 3 de sus 4 lugares de la merindad de Monzón; Becerro, III-19, 29 y 34.

107. En el lugar de Las Lagunas, en la merindad de Silos, el Becerro al registrar el nombre del señor sólo indica de Leyua; XV-85. Siguiendo un criterio arbitrario he atribuido este lugar a Juan Martinez de Leiva, no a Sancho Martínez. 
Fernán Sánchez de Tobar, hijo de Ruy Fernández, figura como señor de 3 behetrías de la zona occidental de Castrojeriz. Como he indicado, la herencia de su padre permanecía indivisa fugurando sus derechos en manos de sus hijos conjuntamente; pero además Fernán Sánchez aparece individualmente en estos tres lugares donde, probablemente, sus derechos no procedían de la herencia paterna.

Dentro del grupo de señores que extienden su poder entre 3 y 9 lugares hay dos casos que merecen una consideración específica, aunque por razones diversas. Se trata de Gonzalo Ibáñez de Amaya y Juan Estébanez de Castellano, ambos señores de 4 lugares. El primero, a juzgar por su apellido toponímico, parece proceder de Amaya en la merindad de Villadiego, pero no figura con derechos señoriales en esas zonas, sino que era señor en 4 condominios de abadengo y solariego compartido en la merindad de Silos. Se trata de Fuentearmejil y sus tres aldeas dependientes, que contaban con un total de 4 señores ${ }^{108}$. Lo más probable es que sus derechos procedan de algún enlace matromonial con alguna de las familias de la zona, pero lo desconozco.

Juan Estébanez de Castellanos dispuso de derechos de señorío también en $\mathbf{4}$ lugares, 3 en el sector oriental de la merindad de Castrojeriz, en la zona de Juarros, y uno en la merindad de Burgos. Sus derechos en la zona de Juarros eran siempre de solariego compartido con otros señores tanto laicos como eclesiásticos; el otro lugar, en la merindad de Burgos, corresponde a Belbimbre, lugar realengo que solia tener por el rey Juan Estábanez. La expresión en pasado no es sorprendente si consideramos que, aunque el Becerro no indica su apellido toponímico, se trataba del canciller regio de Alfonso XI caído en desgracia a comienzos del reinado de Pedro $\mathrm{I}^{109}$.

En resumen, puede decirse que la mayor parte de los nobles que disponían de derechos señoriales entre 3 y 9 lugares eran caballeros comarcales. Hay algunos ricos hombres como Ramir Flórez de Guzmán, Diego López de Haro y Sancha o Martín Gil de Alburquerque, o personajes con un estatus similar como Juan Díaz de Rocaful. Hay también algunos caballeros con proyección regional como Gonzalo González de Lucio y Juan Rodríguez de Villegas. Tanto estos últimos como los ricos hombres, en su mayoría, centrarían el grueso de su poder señorial en zonas que no he estudiado. Pero el resto de los 18 individuos que he analizado responden bastante bien en su mayoría a la calificación de caballeros comarcales. Entre ellos hay algunos que llevan apellidos que comparten con otros nobles más poderosos, los principales miembros de la nobleza regional castellana; son los Alvar Díaz de Sandoval, Juan Sánchez de Velasco, Juan Martínez y Sancho Ruiz de Rojas, etc. Su relación con los nobles más poderosos con los que comparten el apellido no resulta bien conocida en bastantes casos, pero no siempre tiene que corresponder a una relación de parentesco cercano -hermanos, tíos, primos...-. Algunos de estos apellidos corresponden a lo que vengo denominando grupos familiares ${ }^{110}$ muy amplios y entre ellos podía haber diversas ramas separadas incluso a principios del siglo XIII,

108. Becerro, XV-75.

109. S. de MOXO, "Juan Estévanez de Castellanos. Elevación y caida de un consejero regio en la Castilla del siglo XIV", en Homenaje a Fray Justo Pérez de Urbel, I, Santo Domingo de Silos, 1976, pp. 407-421.

110. No todos los nobles que llevaban el apellido de Rojas pertenecían a un sólo linaje en sentido estricto. Lo mismo creo que sucedía con los Sandoval, Carrillo, Villegas... Solamente estudios exhaustivos, que faltan por hacer, permitirán tener certeza en estos aspectos. 
como es el caso de los Rojas. Algunos de los caballeros comarcales de este grupo pueden ser cabezas de linaje de las ramas que adquirieron menor proyección. Otros nobles de este grupo de señores de entre 3 y 9 lugares son caballeros comarcales que, como Pedro García de Grijalba y Gómez Gutiérrez de Quijada, Diego García de Padilla, Juan Fernández de Hinestrosa, etc., corresponden a los individuos más poderosos de sus respectivos grupos familiares; son cabezas de linajes comarcales. Como veremos con más detalle más adelante, junto a estos caballeros comarcales, también habrá otros nobles con los mismos apellidos pero con menor poder señorial que se incluirán en el grupo de caballeros -o escuderos- locales.

La mayor parte de los nobles con proyección señorial entre 3 y 9 lugares poseían el rango de la caballería y son identificables como caballeros sin muchas dificultades. Muchos de ellos o sus padres fueron armados caballeros en la coronación del Alfonso XI. Pero no descarto que este grupo estuviera integrado también por algún escudero. Obviamente, la información sobre estos aspectos es muy incompleta, fuera de algunas listas como las mencionadas. Garcí González de Villaute o Garcí Fernández de Villagutiérrez podrían ser escuderos; en las fuentes que he consultado sus apellidos no aparecen asociados a nobles con el rango de caballeros, aunque insisto en que sólo es una hipótesis.

\subsection{Señores de 1 ó 2 lugares.}

El grupo de nobles con derechos de señorio en 1 ó 2 lugares es muy amplio, integrado por más de 80 referencias individuales ${ }^{111}$. La composición de este grupo es muy variada y de muchos de los individuos que lo integran apenas conozco más datos que los propios que figuran en el Becerro.

Puede distinguirse, en primer lugar, un grupo integrado por ricos hombres y por otros personajes que, sin ser ricos hombres, pueden considerarse como alta nobleza. Entre ellos figuran Fernando Ruiz de Villalobos y Garcí Fernández de Villalobos, hijos de Rodrigo Pérez de Villalobos, cuyos dérechos en ocasiones aparecen registrados en el Becerro individualmente, como los de su otro hermano, Lope Rodríguez, y en otras ocasiones de forma conjunta. Juan García Manrique, tío de Garcí Fernández Manrique -uno de los nobles más poderosos en la zona- y Alvar Núñez de Aza probablemente centraban su poder señorial en otras zonas del reino, pero disponían de derechos señoriales en uno y dos lugares respectivamente. Mayor de Castañeda, madre de Pedro Fernández de Velasco, figura también con derechos propios en dos lugares. Así como la infanta doña Blanca que figura como titular de un lugar de la merindad de Silos, aunque con toda probabiliadad el señorío efectivo de ese lugar estaba en manos de Pedro de Haro. Por último, cabe incluir en este grupo a algunos oficiales regios, como Pedro Suárez de Toledo, Repostero Mayor del Rey, o el Canciller Fernán Sánchez de Valladolid, señores de 1 y 2 lugares respectivamente ${ }^{112}$

111. En el Cuadro figuran 89 entradas porque aparecen también referencias colectivas como, por ejemplo, a los hidalgos de un lugar, a un grupo familiar en conjunto, etc. Por otro lado, no descarto totalmente algún caso de repetición de individuos porque los escasos datos disponibles sobre algunos de ellos impiden una identificación precisa.

112. L.V. DÍAZ MARTín, Los oficiales de Pedro I..., pp. 109; L.V. DÍAZ MARTíN, "Los últimos años de Fernán Sánchez de Valladolid", en Homenaje al Profesor J. Torres Fontes, Murcia, 1987, pp. 349-364; y S. 
Un segundo grupo estaría integrado por individuos cuyos apellidos remiten a la nobleza regional castellana. Puede tratarse de cabezas de linaje que centraban su poder en otras zonas pero que disponian de algunos lugares en las merindades que estudio, o de miembros secundarios de grupos familiares que contaban con individuos más destacados.

Entre los primeros estaría Garcí Laso de la Vega, muerto poco antes de la realización del Becerro; el grueso de sus señoríos estaban en zonas más al norte, pero el Becerro registra, en un caso, sus derechos sobre un lugar de la merindad de Villadiego y, en otro caso, derechos de su hijo en un lugar de la merindad de Cerrato.

También Fernando Díaz Duque era más poderoso en otras zonas, sobre todo en las merindades de Aguilar y de Liébana y Pernía; había muerto ya en 1352 y el Becerro registra derechos de su viuda, Toda González, en un lugar de la merindad de Cerrato.

Martín Alfonso de Arenillas también centraba su poder en la merindad de Aguilar. Por sus señoríos en esa zona también puede ser considerado cabeza de linaje y miembro de la nobleza regional castellana. En la zona que estudio disponía de derechos de solariego compartido en dos lugares de la merindad de Villadiego cercanos a la merindad de Aguilar.

Otros individuos de grupos familiares cuyo poder radicaba en otras zonas eran Diego Gutiérrez de Ceballos y Juan Sánchez de Ayala. Ambos eran individuos secundarios dentro de sus grupos familiares -los preeminentes eran en esos momentos Gutierre Díaz de Ceballos y Fernán Pérez de Ayala-, pero disponían de derechos aislados en un lugar cada uno, dentro de las zonas que estudio.

Pedro Ruiz Carrillo era uno de los noblez más poderosos en la zona, según he indicado. Su hijo, Garci Laso Carrillo disponía de derechos sobre un lugar, derechos que el Becerro registra de manera independiente a Pedro Ruiz.

Sancho Sánchez de Rojas lleva también un apellido que remite al de otros nobles más poderosos, igual que Juan Martínez de Rojas y Sancho Ruiz de Rojas.Todos ellos miembros secundarios del grupo familiar de los Rojas. Sancho Sánchez era señor de un lugar de la zona que estudio y no creo que le unieran lazos de parentesco cercano con Lope Díaz de Rojas, el individuo más destacado en esos momentos entre los Rojas. También los Sandoval y los Villegas eran grupos familiares muy amplios. Como sucedía con los Rojas, algunos nobles con esos apellidos se situaban en los niveles de la nobleza regional, pero otros tenían una proyección mucho menor. Diego Gómez de Sandoval había muerto en 1352 y su viuda Elvira figura como señora de un lugar, lo mismo que Juan Fernández de Sandoval y que otro Juan, hijo de un Diego Gómez de Sandoval apodado el Feo. Entre los miembros del grupo familiar de los Villegas, ya he mencionado a Juan Rodríguez de Villegas y Sancho Ruiz de Villegas, señores de 2 lugares, y a Alfonso López, hijo del anterior y señor de un lugar. Son necesarios estudios exhaustivos que permitan identificar con precisión a los individuos y establecer la relación de todos estos personajes con los miembros más poderosos de sus grupos familiares.

de MOXO, "El patrimonio dominical de un consejero de Alfonso XI. Los señoríos de Fernán Sánchez de Valladolid", en Revista de la Universidad Complutense, vol. XXII, $\mathrm{n}^{\circ} 85$ (1973), Homenaje a Gómez Moreno, II, pp. 123-162. 
Varios individuos con el apellido Torquemada disponían también de señorío en 1 ó 2 lugares de la zona que estudio. Juan Rodriguez de Torquemada tenía derechos señoriales en 2 lugares, su tío Rodrigo Rodríguez de Torquemada en uno y Alvar López de Torquemada en otro. Aparentemente, el personaje que disponía de señoríos más extensos en esta zona de entre los que llevaban el apellido Torquemada era Juana Rodríguez, co-señora de Espeja de San Marcelino y sus 11 aldeas en la merindad de Silos y co-señora también de Hornillos de Cerrato ${ }^{113}$. Pero, como ya he indicado, se trata de un caso peculiar. Por otro lado, el Becerro registra también otro lugar, Canillas de Esgueva en la merindad de Cerrato, bajo el señorío parcial de escuderos de Torquemada ${ }^{14}$. Algunos Torquemada constan como nobles destacados en la zona desde finales del siglo XII y principios del siglo XIII, sin embargo la evolución posterior de este grupo familiar es mal conocida. Por su trayectoria anterior podrían encuadrarse en la nobleza regional, pero su proyección señorial en 1352 era muy reducida y habría que considerarles nobles locales. Algunos Torquemada fueron armados caballeros en la coronación de Alfonso XI pero desconozco la relación, si existía, entre ellos y los señores que figuran en el Becerro; estos últimos podían ser escuderos, no caballeros, tal y como se recoge en el lugar de Canillas de Esgueva.

Entre los nobles que disfrutaban de derechos señoriales en 1 ó 2 lugares encontramos también miembros de los que he definido como linajes comarcales. Los distintos individuos apellidados Torquemada podrían incluirse en ese grupo o en un escalón inmediatamente inferior. Encontramos tanto a nobles cabezas de linaje con proyección comarcal en otras zonas cercanas pero con derechos en 1 ó 2 villas de las merindades que estudio, como a individuos secundarios de grupos familiares cuyos miembros más poderosos tenían proyección comarcal. Los dos nobles que llevan el apellido Cabeza de Vaca son buenos ejemplos de ambos casos. Ruy Díaz Cabeza de Vaca tenía derechos señoriales en un lugar de la merindad de Cerrato y ejercía el señorío de otro lugar en encomienda por el monasterio de San Isidro de Dueñas ${ }^{115}$; Pedro Fernández Cabeza de Vaca había tenido también el señorío de otro lugar de la merindad de Muñó que en 1352 estaba en manos de su viuda Juana Pérez. Sin embargo, el primero parece el individuo preeminente de entre los que llevaban el apellido Cabeza de Vaca en esos momento, y en total podía ejercer derechos señoriales en 7 lugares de las merindades de Cerrato, Infantado de Valladolid, Campos y Carrión, mientras que los derechos de Pedro Fernández se extendían en total por 3 lugares $^{116}$.

Posiblemente Garcí López de Tamayo y su hijo Lope García de Tamayo puedan considerarse también nobles comarcales con proyección local en la zona que estudio. Seguramente García López había muerto ya en 1352 y en un caso el Becerro registra derechos en manos de sus hijos -en plural, sin indicar número ni nombres-, mientras que otro lugar muy próximo figura en manos de su hijo Lope García. Lo más probable es que ambas villas pertenecieran a Lope García en 1352 pero no es completamente seguro. Se trata de dos lugares de la merindad de Burgos con Ubierna ${ }^{117} y$

113. Becerro, XV-73 y I-56 respectivamente.

114. Este logar es solariego e es de Ruy Gutierrez e de Alfonso Dias e de Sancho Diaz, escuderos de Baltanas, e de escuderos de Torquemada e de otros escuderos que se llaman de Coviellas; Becerro, I-8.

115. Becerro. I-87 y 86 respectivamente.

116. En los 7 lugares de Ruy Díaz incluyo también a Santovenia en la merindad de Campos, cuyo señorío ejercía igualmente en encomienda por el monasterio de Dueñas; Becerro, IV-47.

117. Son La Molina de Ubierna y Cobos junto a La Molina; Becerro, XIII-70 y 110. 
los Tamayo, documentados desde el siglo XIII, centraban su patrimonio en zonas inmediatamente al este, en La Bureba que no está registrada en el Becerro.

En el grupo de señores de 1 ó 2 lugares aparecen también varios miembros de los grupos familiares de los Padilla y los Grijalba/Herrera. Entre los primeros están los parientes de Diego García de Padilla y Juan Fernández de Hinestrosa, a quienes consideraba caballeros comarcales. Diego García era hijo de Juan García de Padilla y, aunque los bienes y derechos de este último ya se habían dividido años antes, todavía hay un lugar que aparece bajo el señorío de su viuda y sus hijos legítimos. Puede interpretarse que los derechos estaban indivisos en ese lugar o que se hubiera hecho una división en tres partes iguales. Se trata de Vallegera, lugaar que aparece como solariego de la viuda de Juan García, María González de Hinestrosa, y de sus hijos legítimos, Diego García de Padilla y Maria Díaz (María de Padilla) ${ }^{118}$. Curiosamente, el topónimo de ese lugar pasaría como apellido a otro hijo ilegítimo, Juan García de Vallegera, que no figura con derechos señoriales registrados en el Becerro. Dada la relación familiar de estos Padilla con los Hinestrosa, se puede mencionar también aquí a Martín González de Hinestrosa, hermano de Juan Fernández de Hinestrosa y de la madre de Diego García de Padilla y de María Díaz. Martín González de Hinestrosa compartía con su hermano, que era el cabeza de linaje, el señorío superior de una behetría.

Hay otros Padilla cuya relación con los anteriores desconozco. Como en otros casos, debe tratarse de un grupo familiar amplio cuyas ramas ya se habían ido separando hace tiempo, aunque todos ellos conservaran el mismo apellido de referencia. Curiosamente, los hijos de Juan García de Padilla no eran señores ni diviseros de la behetría de Padilla de Abajo. El señorío superior de ese lugar correspondía a Juan Rodríguez de Sandoval y a otros Padilla: Garcí González de Padilla y Pedro López de Padilla. Este último era hijo de Juan Fernández de Padilla y nieto de otro Pedro López que había tenido un papel político destacado a principios del siglo XIV ${ }^{119}$. Pedro López de Padilla era uno de los herederos de Juan Martínez de Leiva, puesto que estaba casado con una hija suya. Sin embargo, aunque sus orígenes familiares y su enlace matrimonial parecen indicar un nivel superior dentro de la nobleza, su proyección señorial era la propia de un caballero local.

Los Grijalba/Herrera parecen un grupo familiar similar a los Padilla.Algunos de los nobles que llevaban esos apellidos eran caballeros comarcales, otros serían probablemente escuderos con proyección local. El Becerro informa de que García García de Grijalba o de Herrera y Juan Fernández de Grijalba o de Herrera eran hermanos e hijos de otro Garcia García de Grijalba, ya muerto, casado con una Teresa ${ }^{120}$. Teresa compartía el señorío solariego del lugar de Villimar, en la merindad de Castrojeriz, con sus hijos y otros nobles pero, además de su parte, disfrutaba también de la parte de sus hijos ${ }^{121}$. Juan Fernández y su hermano García García compartían el señorío superior de una behetría y el primero era también co-señor de otro lugar. En definitiva, una proyección señorial local con apariencia de estar basada en la herencia

118. Becerro, XI-79.

119. I. ÁLVAREZ BORGE, Estructura social y organización territorial..., pp. 411-412 y 1080-1082.

120. Para la identificación de los personajes, que pueden llevar indistintamente uno u otro apellido, y para las relaciones de parentesco, Becerro, XI-27 y 82 .

121. Becerro, XI-82. 
indivisa de su padre. Además de los lugares donde disponían de derechos señoriales, García García de Grijalba y su hermano Juan Fernández disfrutaban de las martiniegas regias de varios lugares más de la zona ${ }^{122}$. Desconozco la relación entre los hijos de García García de Grijalba y los otros Grijalba con mayor poder señorial: Gómez Gutiérrez y su hermano Pedro García de Grijalba. Otros posibles miembros de este grupo familiar son Muño González de Herrera, señor de un lugar en Cerrato, y un García González que se menciona sin apellido toponímico como co-señor de un lugar en Silos junto a Gómez Gutiérrez de Grijalba.

Otros nobles que pueden identificarse como miembros secundarios de familias o grupos familiares que contaban con individuos más poderosos eran Juan Martínez de Avellaneda, cuyos hijos disfrutaban del señorío compartido sobre dos lugares; Lope Rodriguez de Quijada, cuyos herederos también disfrutaban del señorío compartido en un lugar; o Elvira, identificada como tía de Gutierre Fernández Delgadillo, co-señora también de un lugar.

Los restantes individuos que tenían derechos señoriales con una proyección local resultan prácticamente desconocidos para mí. Sus apellidos no aparecen asociados al rango de caballeros y no tenían derechos señoriales reseñables en otras merindades fuera de las estudiadas. Probablemente muchos de ellos eran escuderos, aunque quizás hubiera algún caballero entre ellos. No sólo tenían un proyección local, sino que además muchos de ellos compartían sus derechos con otros señores.

Como en el grupo de señores de entre 3 y 9 lugares, entre los señores de 1 ó 2 lugares aparecen algunos, muy pocos, ricos hombres o miembros de la alta nobleza. Pero si en el grupo anterior la mayoría de sus miembros detentaban el rango de caballeros, seguramente la mayor parte de los señores locales eran escuderos. Caballeros eran los nobles de proyección regional pero con escasa presencia en la zona que estudio -Fernando Díaz Duque, Martín Alfonso de Arenillas- y debían serlo también la mayoría de los individuos secundarios de esos grupos familiares cuyos miembros más poderosos formaban la nobleza regional -Diego Gómez de Sandoval, Sancho Sánchez de Rojas, etc.-, aunque no dispongo de datos en muchos casos. Lo mismo puede decirse de los nobles que llevan apellidos que remiten a la nobleza comarcal; los cabezas de linaje -Ruy Díaz Cabeza de Vaca- y algunos otros individuos no preeminentes Pedro Fernández Cabeza de Vaca, Pedro López de Padilla- eran caballeros, mientras que de muchos otros no dispongo de datos, aunque sus apellidos sí aparecen asociados frecuentemente al rango de caballeros -los Grijalba, Tamayo, Hinestrosa, Delgadillo, etc. que he citado en este apartado-. Los demás, la gran mayoría de los señores de este grupo de 1 ó 2 lugares, me resultan desconocidos. Algunos constan como caballeros, como Juan García de Villandrando, pero es una excepción; a partir de ahí puede dedu-

122. Son las martiniegas de un total de 11 lugares del sector occidental de la merindad de Castrojeriz. El Becerro explica el origen de esas rentas. Teresa Ceballos había cambiado con el rey las herrerías que poseía en Treceño recibiendo a cambio estas martiniegas; a su muerte las heredó su hija Urraca, casada con Fernando Ladrón de Rojas, y después pasaron a manos de García García y Juan Fernández de Grijalba como herederos de Urraca. En algunos lugares el Becerro considera a Urraca madre de los Grijalba y en otros tía suya, situación esta última que creo más probable, puesto que también indica que la madre de los Grijalba se llamaba Teresa y vivía aún en 1352. La interpretación más probable es que Teresa y Urraca fueran hermanas e hijas de Teresa Ceballos. Becerro, XI-18, 22, 27, 30, 33, 34, 35, 36, 46, 47, 52 y 63; especialmente XI-52. 
cirse, como hipótesis, que la mayoría de ellos eran escuderos; pero es una hipótesis que debe ser contrastada mediante estudios exhaustivos.

\section{CONCLUSIONES. La CONCENTRACIÓN DEL PODER SEÑORIAL Y EL PAPEL DE LOS SECTORES INFERIORES DE LA NOBLEZA.}

La principal conclusión ya ha sido apuntada en ocasiones, hay un alto grado de concentración del poder señorial a mediados del siglo XIV. Tras la cifra global de alrededor de 130 nobles con derechos de señorío en la zona se esconde la realidad de que sólo un pequeño grupo de ellos goza de un poder señorial realmente significativo.Junto a la idea de fragmentación, señalada al comienzo de este artículo, hay que indicar también, por lo tanto, la idea de concentración del poder señorial.

Los nobles más poderosos son ricos-hombres de familias tradicionales como los Lara o los Haro; pero junto a ellos hay otro grupo claramente identificable de cabezas de linaje o de individuos preeminentes de los grupos familiares de la nobleza regional castellana. Son los Lope Díaz de Rojas, Juan Rodríguez de Sandoval, Pedro Fernández de Velasco, etc... Algunos de ellos son incluso los nobles más poderosos de todos los de la zona que he estudiado. Pertenecen a grupos familiares que tienen esa connotación de nobleza regional desde la primera mitad del siglo XIII, aunque las trazas de la sucesión familiar no son siempre bien conocidas. Su posición, por lo tanto, es muy solida desde mucho antes. Pero algunos de ellos pudieron protagonizar un proceso de ascenso, partiendo de esas posiciones, desde finales del siglo XIII y durante la primera mitad del XIV. Cada caso concreto tiene sus propias características pero en ese proceso de ascenso parece que hubo dos factores que jugaron un papel relevante. En primer lugar, la posición política de los individuos en el contexto de las crisis de las minorías y las revueltas nobiliarias desde 1270 hasta 1325 . Es decir, la relación con los reyes, que se concreta en que muchos de ellos ocuparon puestos relevantes en la administración de la monarquía ${ }^{123}$. El segundo factor relevante en su ascenso social son sus enlaces matrimoniales que, cuando se conocen bien -que es en pocos casos- se muestran como un elemento estratégico de primer orden en la adquisición de derechos señoriales.

Buena parte de los derechos señoriales de estos caballeros radica en villas de behetría. Su situación como cabezas de linaje coincide con su carácter de señores singulares de behetría. Es decir, se sitúan como cabezas de linajes o individuos preeminentes dentro de sus grupos familiares y esa preeminencia se concreta, entre otras cosas, en el disfrute del señorío singular de las behetrías. ¿Cómo lo lograron? es algo que se conoce bastante mal y quizás cada caso tenga sus características particulares. La consolidación del señorío singular de las behetrías durante el siglo XIII parece un elemento a tener en cuenta. La propia evolución biológica de las familias es muy importante.Y creo que también influyó, de nuevo, el rey directa o indirectamente, aunque sólo fuera por la vía de resolver en un sentido o en otro los pleitos por derechos

123. R. PÉREZ BUSTAMANTE, El gobierno y la administración territorial de los reinos de la Corona de Castilla (1230-1447), Madrid, 1976; C. JULAR, Los Adelantados y Merinos Mayores del reino de León (ss. XIII-XV), León 1990; I. ÁLVAREZ BORGE, Monarquía feudal y organización territorial. Alfoces $y$ merindades en Castilla (siglos X-XIV), Madrid, 1993. 
sucesorios y repartos hereditarios. El caso que mejor conozco es el de Lope Díaz de Rojas y mi conclusión es que no fue un proceso sencillo. En su proceso de adquisición de esa preeminencia que se refleja en el Becerro intervinieron compras a otros miembros de su familia pero también conflictos, confictos violentos que en algunas fuentes no se presentan en primer lugar como conflictos familiares -el cronista de Alfonso XI no hubiera tenido ningún interés en recogerlos- sino como componentes de los grandes conflictos políticos. El rey, por ejemplo, apoya en algún momento a Garcí Laso II de la Vega, frente a Lope Díaz de Rojas que era vasallo del oponente del rey, don Juan Manuel. Hay destrucciones de castillos, luchas violentas y asesinatos - ¿o ajusticiamientos?-, pero finalmente el de la Vega no logra sus pretensiones que eran las fortalezas del de Rojas, reclamando los derechos de herencia que correspondían a su primera mujer, hermana mayor de Lope Díaz de Rojas. También las circunstancias biológicas intervinieron a favor de Lope Díaz de Rojas, porque sus hermanos mayores murieron en un breve espacio de tiempo ${ }^{124}$.

Sea como fuere el Becerro muestra la existencia de individuos principales que concentran en sus manos derechos señoriales de sus grupos familiares a mediados del siglo XIV. Cabe preguntarse si antes de mediados del siglo XIV se puede encontrar una estructura tan jerárquica de los grupos familiares nobiliarios. Mi hipótesis considera que la organización jerárquica de los grupos familiares nobiliarios podría estar relacionada con el proceso de ascenso social que protagonizaron algunos individuos. Podría plantearse la hipóteisis de que quienes ascendieron lo hicieron, entre otros medios, absorbiendo los derechos señoriales de sus grupos familiares y también que esa concentración de derechos les permitió ascender más.

Hay que tener en cuenta que no todos los grupos familiares sólidamente asentados desde el siglo XIII vivieron el mismo proceso. Por ejemplo, no parece claro que entre los Carrillo pueda hablarse de un individuo principal de la misma manera que entre los Rojas o los Sandoval o los Velasco. Tampoco se ve eso mismo con toda claridad entre los Villegas o los Padilla. Entre estos otros grupos familiares abundan los caballeros pero su proyección era menor que la de los personajes que acabo de citar unas líneas más arriba.

Los grupos familiares engloban situaciones muy diversas para sus miembros. Es necesario considerar que había muchos más Rojas que Lope Díaz, muchos más Sandoval que Juan Rodríguez, etc. Finalmente, si no se adquieren los señoríos de las behetrías donde tiene derechos la familia, el poder señorial de cada individuo es estrictamente el que le corresponde como individuo. Otra cosa es que su proyección social esté en parte condicionada por sus relaciones de parentesco; es decir, que sus relaciones de parentesco le sitúen con facilidad dentro de unas u otras clientelas nobiliarias, que también actúan como elementos generadores de poder. Pero esto consistirá, sobre todo, en acceder a mecanismos de poder por cesión del noble principal-señor, como ha estudiado C. Jular para algunos de los clientes-parientes de Pedro Fernández de Velasco ${ }^{125}$.

124. Cronica de Alfonso XI,pp. 264.Analizo estos aspectos con más detalle en la monografia que preparo sobre los Rojas.

125. C. JULAR, "Dominios señoriales y relaciones clientelares...". 
En este artículo, con un criterio arbitrario, he dividido la proyección señorial de los nobles en 4 grupos: los señores de más de 20 lugares, señores de entre 9 y 19 lugares, señores de entre 3 y 9 lugares y señores de 1 ó 2 lugares. Los ricos hombres, los caballeros integrados en la alta nobleza y los caballeros de la nobleza regional integran los dos primeros grupos fundamentalmente. Tanto unos como otros aparecen en los grupos que recogen a los señores menos poderosos pero, en esos casos, o bien se trata de individuos que centran el grueso de su poder en otras zonas y para quienes sus señoríos en las merindades que estudio eran un tanto marginales, o bien se trata de casos que responden a situaciones específicas que ya he ido indicando con detalle. El grueso de los nobles que figuran en el grupo de señores de entre 3 y 9 lugares corresponden a lo que podemos denominar caballeros comarcales. De muchos de ellos consta su condición de caballeros y la proyección señorial, por su extensión, puede calificarse de comarcal. En este grupo y en el inferior es donde la complejidad de los grupos familiares -entendiendo por tales a los grupos de individuos que llevan el mismo apellido de referencia- se hace evidente. Entre los caballeros comarcales aparecen nobles que portan apellidos que comparten con otros mucho más poderosos que ellos -Sandoval, Rojas...-. Se trata de nobles que, o bien no son cabezas de linaje, o bien serían cabezas de ramas secundarias separadas, en algunos casos, hacía ya varias generaciones. Su situación era muy parecida a la de otros nobles, también caballeros comarcales, que sí podian ser cabezas de linaje, pero cuyos apellidos remiten al ámbito comarcal. Seguramente es más lógico equiparar a Juan Sánchez de Velasco con Diego García de Padilla -antes de que éste ascendiera a la alta nobleza por la relación de su hermana con el rey- que con Pedro Fernández de Velasco. La composición del escalón inferior, el grupo de nobles señores sólo de 1 ó 2 lugares, permite añadir que, además de los cabezas de linaje comarcales, también esos grupos familiares tenían una composición compleja, con indiviuos no preeminentes o ramas secundarias. La diferencia es que, probablemente, ahora en muchos casos ya no se trata de caballeros, sino de escuderos. Su situación sería similar a la de muchos otros escuderos o hidalgos locales de cuya existencia y condición apenas queda más información que la que se deriva de aparecer mencionados una o dos veces en el Becerro. Sin embargo, ellos son el grupo más numeroso.

Del análisis realizado es posible extraer algunas ideas que, a mi juicio, son relevantes. El ejercicio de derechos señoriales, como ya se ha indicado en varias ocasiones, es un indicador de la jerarquía nobiliaria. En relación con ello, las bases materiales del poder de los nobles de los sectores inferiores derivaban de mecanismos distintos al señorío, aunque relacionados con él. Es interesante, además, tener en cuenta que la fragmentación señorial -característica estructural del sistema en la zona- es más importante entre los sectores inferiores de la nobleza que entre los superiores. De las 89 referencias a señores de 1 ó 2 lugares, sólo 25 individuos podían ejercer el señorío en algún caso de forma exclusiva y esa circunstancia se daba en 29 lugares ${ }^{126}$. Sin embargo, de los 16 nobles señores de más de 10 lugares -excluyo aquí al rey y la reina- todos menos Juana Rodríguez de Tarquemada podian ejercer el señorío en algún caso de forma exlusiva, ejerciendo esos derechos en un total de 183 lugares ${ }^{127}$. Puede decirse, por

126. Además, entre esos 25 individuos aparecen 4 ricos hombres y miembros de la alta nobleza (la infanta doña Blanca, Juan García Manrique, Alvar Núñez de Aza y Fernando Ruiz de Villalobos) 2 oficiales importantes del rey (Pedro Suárez de Toledo y Fernán Sánchez de Valladolid) y otros nobles más poderoso en otras zonas (Ruy Díaz Cabeza de Vaca, Garcí Laso Carrillo, etc. ).

127. Teniendo en cuenta, también, que 137 de esos 183 lugares eran behetrías. 
lo tanto, que una característica de los sectores inferiores de la nobleza es que apenas tenían derechos de señorío y que, cuando los tenían, casi siempre los ejercían de manera compartida. Siendo así, es necesario plantear al menos cuáles serían las bases de su poder. La respuesta, en mi opinión, es la apropiación de excedente mediante otros recursos distintos del señorío -dominio señorial-, los recursos y capacidades derivados de lo que se puede denominar propiedad dominical ${ }^{128}$; el control de hombres y tierras y la extracción de excedente de campesinos sometidos al señorío de otros señores.Y esto en varios sentidos. En primer lugar, mediante sus propias capacidades de desarrollar su propiedad dominical, sus dominios. Aunque los problemas de fuentes son muy importantes, resulta de gran interés reconstruir con la mayor precisión posible los dominios de estos nobles ${ }^{129}$. En segundo lugar, mediante la participación en la administración y explotación de los dominios de otros nobles laicos e instituciones eclesiásticas. Esto, también, de diversas maneras, algunas formalizadas jurídicamente y otras no. Mediante arrendamientos y ocupando cargos como oficiales en la administración de los grandes dominios, por ejemplo, pero también mediante usurpaciones, malfetrías, etc. Me he referido a estos aspectos en un trabajo anterior y no me detendré ahora en ellos ${ }^{130}$. Pero merece la pena destacar un elemento mal conocido como es el de las clientelas nobiliarias. En relación con la participación de los sectores inferiores de la nobleza en los recursos generados en otros dominios, por otros señores, hay que tener en cuenta la percepción de remuneraciones en metálico, la participación en rentas derivadas de relaciones clientelares. Se conocen las relaciones de este tipo establecidas por los reyes con algunos nobles, ricos hombres y caballeros sobre todo, pero resultan igualmente importantes las relaciones clientelares que, a su vez, establecieron los ricos hombres y los caballeros más poderosos con otros nobles de los sectores inferiores ${ }^{131}$. Este tipo de remuneraciones en metálico o de participación en rentas, tanto regias como señoriales, que en Inglaterra han sido caracterizadas como feudalismo bastardo, pudieron constituir una de las principales bases económicas de amplios sectores de la nobleza, más aún en los momentos de la primera mitad del siglo XIV, cuando la caballería se presentaba como un instrumento de cohesión internobiliaria, mediante el establecimiento de nuevos y poderosos vínculos de patronazgo.

Baja nobleza, como opuesto a alta nobleza, son conceptos sin duda útiles pero insuficientes. Un análisis más detallado muestra una jerarquía más compleja. Un medio de hacer ese análisis -puede haber otros- es estudiando el señorío, puesto que nos permite establecer gradaciones. Es especialmente útil porque muestra coincidencias con la jerarquía de estatus que se desarrolla durante la primera mitad del siglo XIV.

128. Sobre estos conceptos C. ESTEPA, "Formación y consolidación...".

129. Véase P. MARTÍNEZ, La Tierra de Campos..., pp. 405-422; y C. REGLERO, Los señoríos de los Montes de Torozos..., pp. 137-149.

130. I. ÁLVAREZ BORGE, Poder y relaciones sociales..., pp. 152-172.

131. Destacan, sobre estos aspectos, los trabajos recientes de C. JULAR, "Dominios señoriales y relaciones clientelares..." "La participación de un noble en el poder local a través de clientela. Un ejemplo concreto de fines del siglo XIV", en Hispania, 185 (1993), pp. 861-884; “Los bienes prestados: estrategias feudales de consolidación señorial”, en VIII Congreso de Historia Agraria, Salamanca, 1997, pp. 295-310. 
ANEXO

Señores de las merindades de Cerrato, Villadiego, Castrojeriz, Muñó, Burgos con Ubierna y Silos según el Becerro de las Behetrías.

Tras el nombre de cada noble figura el número total de lugares donde dispone de derechos señoriales.

La columna "Mer." se refiere a la/s merinad/es donde se encontraba cada lugar. Sigo la numeración (en romanos) que figura en la edición del Becerro por Martínez Diez; así, I corresponde a la merindad de Cerrato,VI a Villadiego, XI a Castrojeriz, XII a Muñó, XIII a Burgos con Ubierna y XV a Silos.

La columna " $\mathrm{N}^{\circ}$ " se refiere al número del epígrafe de cada lugar en su merindad, según la edición citada.

La columna "Tipo" refleja la situación señorial de cada lugar. Abrevio abadengo como " $A$ ", behetría como " $B$ ", realengo como " $R$ " y solariego como " $S$ ", poniendo tantas siglas como señores haya; de manera que, por ejemplo, AASS corresponde a un lugar condominio de abadengo y solariego con 2 señores eclesiásticos y otros 2 laicos, etc.

La columna "Srs." recoge el número total de señores con derechos en cada lugar.

En la columna "Otros" figuran otros datos de interés relativos a cada lugar; por ejemplo, el número de solares que tenía el señor correpondiente -cuando tal dato figura en el Becerro-, o si los derechos proceden de la esposa, o si corresponden a los herederos, etc.

\begin{tabular}{|c|c|c|c|c|c|c|c|}
\hline Señor & & Lugar & Mer. & $\mathbf{N}^{o}$ & Tipo & Srs. & Otros \\
\hline \multicolumn{8}{|c|}{ Juan Rodríguez } \\
\hline & & Castrillo de Don Juan & I & 10 & AASS & 4 & \\
\hline & & Peral de Arlanza & I & 23 & B & 1 & 1 solar \\
\hline & & Cobos de Cerrato & I & 25 & B & 1 & \\
\hline & & Villaconancio & I & 42 & ASSS & 4 & Su mujer Juana \\
\hline & & Villella & I & 50 & $\mathrm{~B}$ & 1 & \\
\hline & & Antigüedad & I & 51 & B & 1 & \\
\hline & & Valverde & I & 52 & $\mathrm{~S}$ & 1 & \\
\hline & & Villalba & $\mathbf{I}$ & 53 & B & 1 & Yermo \\
\hline & & Terrados & I & 54 & $\mathrm{~B}$ & 1 & \\
\hline & & Baltanás & I & 55 & AASS & 4 & \\
\hline & & Hornillos de Cerrato & I & 56 & SSSSSSS & 7 & \\
\hline & & Valdecañas de Abajo & I & 57 & B & 1 & \\
\hline & & Valdecañas de Cerrato & I & 58 & B & 1 & \\
\hline & & Villabaya & I & 59 & B & 1 & \\
\hline & & Villarmiro & I & 60 & B & 1 & \\
\hline & & Herrrera de Valdecañas & I & 61 & B & 1 & \\
\hline & & Villagero & I & 65 & B & 1 & \\
\hline & & Castrillejo & I & 66 & B & 1 & \\
\hline & & Moral & I & 69 & SS & 2 & \\
\hline & & Quintana del Puente & I & 71 & $\mathrm{~B}$ & 1 & \\
\hline
\end{tabular}




\begin{tabular}{|c|c|c|c|c|c|c|c|}
\hline Señor & & Lugar & Mer. & $\mathbf{N}^{\mathbf{o}}$ & Tipo & Srs. & Otros \\
\hline & & Villandrando & I & 72 & SSS & 3 & \\
\hline & & Villambistia & I & 73 & B & 1 & \\
\hline & & Torquemada & I & 74 & B & 1 & \\
\hline & & Quintana Sandino & I & 75 & B & 1 & \\
\hline & & Fuentesalce & I & 76 & B & 1 & \\
\hline & & Valdeolmillos & I & 79 & B & 1 & \\
\hline & & Fuentes de Valdepero & I & 82 & $S$ & 1 & \\
\hline & & Fuencaliente de Puerta & VI & 17 & $\mathrm{~B}$ & 1 & \\
\hline & & Sandoval de la Reina & VI & 31 & BB & 2 & \\
\hline & & Villaute & VI & 35 & B & 1 & \\
\hline & & Boada de Villadiego & VI & 40 & B & 1 & \\
\hline & & Brulles & VI & 43 & BB & 2 & \\
\hline & & Tudanca de Arriba & VI & 46 & B & 1 & 1 solar \\
\hline & & Santa María de Añanúñez & VI & 96 & SS & 2 & \\
\hline & & Vallecillo & XI & 4 & B & 1 & \\
\hline & & Castrillo de Murcia & $\mathrm{XI}$ & 8 & B & 1 & \\
\hline & & Valbuena de Pisuerga & $\mathrm{XI}$ & 9 & B & 1 & \\
\hline & & Revilla-Vallegera & $\mathrm{XI}$ & 16 & B & 1 & \\
\hline & & Villandiego & $\mathrm{XI}$ & 45 & $\mathrm{~B}$ & 1 & \\
\hline & & Grajera & $\mathrm{XI}$ & 45,1 & B & 1 & \\
\hline & & Quintanilla de Grajera & XI & 45,2 & B & 1 & \\
\hline & & Yudego & XI & 49 & B & 1 & \\
\hline & & Arenillas de Río Pisuerga & $\mathrm{XI}$ & 53 & B & 1 & \\
\hline & & Padilla de Arriba & XI & 54 & B & 1 & \\
\hline & & Padilla de Abajo & XI & 55 & BBB & 3 & \\
\hline & & Villamiel de la Sierra & XI-B & 94 & ASSSS & 5 & Su mujer \\
\hline & & Solarana & XII & 39 & $\mathbf{S}$ & 1 & \\
\hline & & Cilleruelo de Arriba & $X V$ & 128 & B & 1 & \\
\hline & & Nebreda & $X V$ & 129 & B & 1 & \\
\hline \multicolumn{8}{|c|}{ Garcí Fernández } \\
\hline \multirow[t]{17}{*}{ Manrique } & 34 & Villaverde Mogina & I & 68 & $\mathrm{ABB}$ & 3 & \\
\hline & & Talamillo del Tozo & VI & 18 & $\mathrm{~B}$ & 1 & \\
\hline & & Cuevas de Puerta & VI & 19 & B & 1 & \\
\hline & & Trashedo & VI & 56 & SS & 2 & 3 solares \\
\hline & & Prádanos del Tozo & VI & 57 & SS & 2 & 4 solares \\
\hline & & Villoba & VI & 58 & SSS & 3 & 4 solares \\
\hline & & Barrio Panizares & VI & 59 & SSS & 3 & 6 solares \\
\hline & & La Piedra & VI & 64 & SS & 2 & 8 solares \\
\hline & & Santa Cruz del Tozo & VI & 66 & $\mathrm{~S}$ & 1 & \\
\hline & & Urbel del Castillo & VI & 67 & $\mathbf{S}$ & 1 & \\
\hline & & Quintana del Pino & VI & 68 & $\mathrm{~S}$ & 1 & \\
\hline & & Nuez de Arriba & VI & 70 & $S$ & 1 & \\
\hline & & Fuente Urbel & VI & 102 & SS & 2 & Yermo \\
\hline & & Palacios de Benaver & XI & 31 & $\mathrm{AB}$ & 2 & \\
\hline & & Villorejo & $\mathrm{XI}$ & 36 & $\mathrm{~B}$ & 1 & \\
\hline & & Isar & XI & 97 & $\mathrm{~S}$ & 1 & \\
\hline & & Celadilla del Rebollar & XIII & 2 & $\mathbf{B}$ & 1 & \\
\hline
\end{tabular}




\begin{tabular}{|c|c|c|c|c|c|c|c|}
\hline Señor & & Lugar & Mer. & $N^{o}$ & Tipo & Srs. & Otros \\
\hline & & Celada de la Torre & XIII & 3 & B & 1 & \\
\hline & & Sotrajero & XIII & 11 & B & 1 & \\
\hline & & Marmellar de Abajo & XIII & 19 & B & 1 & \\
\hline & & Vivar del Cid & XIII & 58 & B & 1 & \\
\hline & & Ubierna & XIII & 59 & $S$ & 1 & \\
\hline & & San Martín de Ubierna & XIII & 59,1 & $S$ & 1 & \\
\hline & & Sotopalacios & XIII & 61 & $S$ & 1 & \\
\hline & & Celadilla-Sotobrín & XIII & 65 & $\mathbf{S}$ & 1 & \\
\hline & & Gredilla la Polera & XIII & 69 & B & 1 & \\
\hline & & La Molina de Ubierna & XIII & 70 & ASS & 3 & \\
\hline & & Quintanala & XIII & 75 & $\mathrm{~S}$ & 1 & \\
\hline & & Robredo-Sobresierra & XIII & 79 & B & 1 & \\
\hline & & Quintanaortuño & XIII & 82 & B & 1 & \\
\hline & & Riocerezo & XIII & 86 & BB & 2 & \\
\hline & & Escalada & XIII & 100 & SSS & 3 & \\
\hline & & Villanueva de Río Ubierna & XIII & 102 & B & 1 & \\
\hline & & Ventosilla & $\mathrm{XV}$ & 97 & SS & 2 & \\
\hline \multicolumn{8}{|c|}{ Juan Martínez de } \\
\hline \multirow[t]{29}{*}{ Leiva } & 27 & Hacinas & $X V$ & 16 & ASS & 3 & Su viuda Juana \\
\hline & & Tolbaños de Arriba & $\mathrm{XV}$ & 43 & Ssss & 4 & Sus hijos \\
\hline & & Huerta de Abajo & $X V$ & 44 & SSSSS & 5 & Sus hijos \\
\hline & & Tolbaños de Abajo & $\mathrm{XV}$ & 45 & SSSSS & 5 & Sus hijos \\
\hline & & Huerta de Arriba & $\mathrm{XV}$ & 46 & SSSS & 4 & Sus hijos \\
\hline & & Riocavado de la Sierra & $\mathrm{XV}$ & 47 & Sssss & 5 & Sus hijos \\
\hline & & Barbadillo de los & & & & & \\
\hline & & Herreros & $\mathrm{XV}$ & 49 & SSSSS & 5 & Sus hijos \\
\hline & & Espeja de San & & & & & \\
\hline & & Marcelino & $\mathrm{XV}$ & 73 & AASSSS & 6 & Sus hijos \\
\hline & & Orillares & $\mathrm{XV}$ & 73,1 & AASsSS & 6 & Sus hijos \\
\hline & & La Lodosa & $X V$ & 73,11 & AASSSS & 6 & Sus hijos \\
\hline & & Aldea de Suso & $\mathrm{XV}$ & 73,12 & AASssS & 6 & Sus hijos.Yermo \\
\hline & & Santovenia & $\mathrm{XV}$ & 73,2 & AASSSS & 6 & Sus hijos \\
\hline & & Guijosa & $X V$ & 73,3 & AASSSS & 6 & Sus hijos \\
\hline & & La Hinojosa & $\mathrm{XV}$ & 73,4 & AASSSS & 6 & Sus hijos \\
\hline & & Cabañuelas & $\mathrm{XV}$ & 73,5 & AASSSS & 6 & Sus hijos \\
\hline & & San Asenjo & $X V$ & 73,6 & AASSSS & 6 & Sus hijos \\
\hline & & Ledigo & $\mathrm{XV}$ & 73,7 & AASSSS & 6 & Sus hijos.Yermo \\
\hline & & Pisana & $X V$ & 73,8 & AASSSS & 6 & Sus hijos.Yermo \\
\hline & & Pioza & $\mathrm{XV}$ & 73,9 & AASSSS & 6 & Sus hijos.Yermo \\
\hline & & Fuentearmejil & $\mathrm{XV}$ & 75 & ASSS & 4 & Sus hijos \\
\hline & & Ribalba & $\mathrm{XV}$ & 75,1 & Asss & 4 & Sus hijos \\
\hline & & Santervás & $X V$ & 75,2 & ASSS & 4 & Sus hijos \\
\hline & & Zayuelas & $X V$ & 75,3 & ASSS & 4 & Sus hijos \\
\hline & & Quemada & $X V$ & 80 & S & 1 & Sus hijos \\
\hline & & Las Lagunas & $\mathrm{XV}$ & 85 & B & 1 & \\
\hline & & Coruña del Conde & $\mathrm{XV}$ & 88 & SS & 2 & $\begin{array}{l}\text { Su viuda Juana } \\
\text { y sus hijos }\end{array}$ \\
\hline & & Alcoba del Camino & $\mathrm{XV}$ & 94 & SSS & 3 & Su viuda Juana \\
\hline
\end{tabular}


NOBLEZA Y SEÑORÍOS EN CASTILLA LA VIEJA MERIDIONAL A MEDIADOS DEL SIGLO XIV

\begin{tabular}{|c|c|c|c|c|c|c|c|}
\hline Señor & & Lugar & Mer. & $\mathbf{N}^{o}$ & Tipo & Srs. & Otros \\
\hline \multirow[t]{28}{*}{ Nuño de Lara } & \multirow[t]{28}{*}{26} & Cevico de la Torre & I & 38 & S & 1 & \\
\hline & & Hornillos de Cerrato & I & 56 & SSSSSSS & 7 & \\
\hline & & Villamediana & I & 77 & B & 1 & \\
\hline & & San Pedro & I & 77,1 & $\mathrm{~B}$ & 1 & \\
\hline & & Quintanilla de & & & & & \\
\hline & & Valdeolmillos & I & 78 & B & 1 & \\
\hline & & Reinoso de Cerrato & I & 89 & $\mathrm{AB}$ & 2 & \\
\hline & & Villusto & VI & 74 & $\mathrm{~S}$ & 1 & \\
\hline & & Espinosa de & & & & & \\
\hline & & Valdeolmos & XI & 11 & B & 1 & \\
\hline & & Boadilla del Camino & XI & 13 & B & 1 & \\
\hline & & Los Balbases & XI & 15 & B & 1 & \\
\hline & & Sasamón & XI & 42 & B & 1 & \\
\hline & & Santa María Pelayo & XI & 59 & $\mathrm{AB}$ & 2 & \\
\hline & & Villalmanzo & XII & 42 & $\mathrm{~S}$ & 1 & \\
\hline & & Lerma & XII & 43 & $S$ & 1 & \\
\hline & & Revilla-Cabriada & XII & 44 & $\mathrm{~S}$ & 1 & \\
\hline & & Quintanilla de la Mata & XII & 45 & $S$ & 1 & \\
\hline & & Villoviado & XII & 46 & S & 1 & \\
\hline & & Ruyales del Agua & XII & 47 & $\mathbf{S}$ & 1 & \\
\hline & & Pinilla de los Moros & $X V$ & 27 & BBB & 3 & \\
\hline & & Neila & $X V$ & 59 & B & 1 & \\
\hline & & Quintanilla del Agua & $X V$ & 114 & B & 1 & \\
\hline & & San Pedro de la Villa & XV & 115 & B & 1 & \\
\hline & & Cebrecos & XV & 118 & B & 1 & \\
\hline & & Tordomar & XV & 121 & B & 1 & \\
\hline & & Santa Cecilia & XV & 123 & B & 1 & \\
\hline & & Pinedillo & XV & 124 & B & 1 & \\
\hline \multirow[t]{18}{*}{ Pedro Ruiz Carrillo } & \multirow[t]{18}{*}{25} & Pinilla de Arlanza & I & 22 & $\mathrm{~S}$ & 1 & \\
\hline & & Cubillo del Campo & XI-B & 60 & B & 1 & \\
\hline & & Hontoria de la Cantera & XI-B & 61 & B & 1 & \\
\hline & & Hontoria de Yuso & XI-B & 62 & BB & 2 & Su mujer Urraca \\
\hline & & Revenga & XII & 6 & B & 1 & \\
\hline & & Villarte & XII & 9 & $\mathrm{~B}$ & 1 & \\
\hline & & Mahamud & XII & 19 & B & 1 & \\
\hline & & Bascones & XII & 28 & $\mathrm{~B}$ & 1 & \\
\hline & & San Pedro de Vellota & XII & 48 & $\mathrm{R}$ & 1 & Casa de \\
\hline & & & & & & & Villavieja \\
\hline & & Quintanaseca & XII & 51 & $\mathrm{R}$ & 1 & $\begin{array}{l}\text { Casa de } \\
\text { Villavieja }\end{array}$ \\
\hline & & Villaquirán de los Infantes & XII & 70 & $\mathrm{~S}$ & 1 & \\
\hline & & Sarracín & XIII & 32 & $\mathrm{~B}$ & 1 & . \\
\hline & & Quintanilla Cojobar & XIII & 33 & B & 1 & Yermo \\
\hline & & Espeja de & & & & & \\
\hline & & San Marcelino & $\mathrm{XV}$ & 73 & AASSSS & 6 & \\
\hline & & Orillares & $X V$ & 73,1 & AASSSS & 6 & \\
\hline & & La Lodosa & $\mathrm{XV}$ & 73,11 & AASSSS & 6 & Yermo \\
\hline
\end{tabular}




\begin{tabular}{|l|l|l|l|l|l|l|}
\hline Señor & Lugar & Mer. & $\mathrm{N}^{\circ}$ & Tipo & Srs. & Otros \\
\hline & Aldea de Suso & $\mathrm{XV}$ & 73,12 AASSS & 6 & Yermo \\
& Santovenia & $\mathrm{XV}$ & 73,2 & AASSSS & 6 & \\
& Guijosa & $\mathrm{XV}$ & 73,3 & AASSSS & 6 & \\
& La Hinojosa & $\mathrm{XV}$ & 73,4 AASSSS & 6 & \\
& Cabañuelas & $\mathrm{XV}$ & 73,5 & AASSSS & 6 & \\
& San Asenjo & $\mathrm{XV}$ & 73,6 & AASSSS & 6 & \\
& Ledigo & $\mathrm{XV}$ & 73,7 & AASSSS & 6 & Yermo \\
& Pisana & $\mathrm{XV}$ & 73,8 AASSSS & 6 & Yermo \\
& Pioza & $\mathrm{XV}$ & 73,9 AASSSS & 6 & Yermo \\
\end{tabular}

Pedro Fernández de Velasco

Cueva de Juarros
Santa Cruz de Juarros
Brieva de Juarros
Salguero de Juarros
Villamiel de la Sierra
Hortigüela
Castrillo de la Reina
Salas de los Infantes
Quintanilla del Coco
Cascajares de la Sierra
Monasterio de la Sierra
Arroyo de Salas
Hoyuelos de la Sierra
Vallejimeno
Bezares
Tolbaños de Arriba
Huerta de Abajo
Tolbaños de Abajo
Huerta de Arriba
Riocavado de la Sierra
Quintanilla de Urrilla
Barbadillo de los Herreros
Hornillos
Palacios de la Sierra

$\begin{array}{lllll}\text { XI-B } & 88 & \text { ASS } & 3 & \\ \text { XI-B } & 91 & \text { AAAS } & 4 & \\ \text { XI-B } & 92 & \text { AAAS } & 4 & \\ \text { XI-B } & 93 & \text { AS } & 2 & 7 \text { solares } \\ \text { XI-B } & 94 & \text { ASSSS } & 5 & \\ \text { XV } & 3 & \text { AS } & 2 & \\ \text { XV } & 5 & \text { B } & 1 \\ \text { XV } & 10 & \text { B } & 1 \\ \text { XV } & 11 & \text { B } & 1 \\ \text { XV } & 32 & \text { AS } & 2 \\ \text { XV } & 36 & \text { B } & 1 \\ \text { XV } & 37 & \text { B } & 1 \\ \text { XV } & 38 & \text { B } & 1 \\ \text { XV } & 40 & \text { SS } & 2 \\ \text { XV } & 42 & \text { S } & 1 \\ \text { XV } & 43 & \text { SSSS } & 4 \\ \text { XV } & 44 & \text { SSSSS } & 5 \\ \text { XV } & 45 & \text { SSSSS } & 5 \\ \text { XV } & 46 & \text { SSSS } & 4 \\ \text { XV } & 47 & \text { SSSSS } & 5 \\ \text { XV } & 48 & \text { SSSS } & 4 \\ \text { XV } & 49 & \text { SSSSS } & 5 \\ \text { XV } & 63 & \text { SS } & 2 \\ \text { XV } & 71 & \text { SSS } & 3\end{array}$

Lope Díaz de Rojas

Mundilla de Valdelucio
Villamartín de Villadiego
Rebolledo de Traspeña
Rioparaíso
Villavedón
Rebolleda
Valtierra de Albacastro
Palazuelos de Villadiego
Amaya
Ordejón
Quintanilla-Pedro Abarca

$\begin{array}{llll}\text { VI } & 2 & \text { B } & 1 \\ \text { VI } & 14 & \text { B } & 1 \\ \text { VI } & 15 & \text { B } & 1 \\ \text { VI } & 36 & \text { B } & 1 \\ \text { VI } & 38 & \text { B } & 1 \\ \text { VI } & 51 & \text { B } & 1 \\ \text { VI } & 52 & \text { B } & 1 \\ \text { VI } & 75 & \text { S } & 1 \\ \text { VI } & 82 & \text { S } & 1 \\ \text { VI } & 86 & \text { S } & 1 \\ \text { XI } & 21 & \text { B } & 1\end{array}$




\begin{tabular}{|c|c|c|c|c|c|c|c|}
\hline Señor & & Lugar & Mer. & $\mathrm{N}^{o}$ & Tipo & Srs. & Otros \\
\hline & & Ros & $\mathrm{XI}$ & 23 & B & 1 & \\
\hline & & Miñón & XI & 24 & $\mathrm{~B}$ & 1 & \\
\hline & & Los Tremellos & XI & 26 & $\mathrm{BB}$ & 2 & \\
\hline & & Monasteruelo & XI & 28 & $\mathrm{~B}$ & 1 & \\
\hline & & Ruyales del Páramo & XI & 29 & $\mathrm{~B}$ & 1 & \\
\hline & & Zumel & XI & 35 & BB & 2 & \\
\hline & & Huérmeces & $\mathrm{XI}$ & 38 & B & 1 & \\
\hline & & San Pantaleón del Páramo & $\mathrm{XI}$ & 39 & $\mathrm{~B}$ & 1 & \\
\hline & & Santibáñez-Zarzaguda & XI & 40 & $\mathrm{~B}$ & 1 & \\
\hline & & Las Rebolledas & $\mathrm{XI}$ & 41 & $\mathrm{~B}$ & 1 & \\
\hline & & Mansilla de Burgos & $\mathrm{XI}$ & 100 & SS & 2 & \\
\hline & & Riocerezo & XIII & 86 & BB & 2 & \\
\hline \multirow[t]{22}{*}{ Gómez Carrillo } & 22 & Hontoria de Río Franco & I & 24 & B & 1 & \\
\hline & & Mozoncillo de Juarros & XI-B & 87 & AS & 2 & \\
\hline & & Revilla del Campo & XI-B & 108 & AAS & 3 & 1 solar \\
\hline & & Huerta de Abajo & $\mathrm{XV}$ & 44 & SSSSS & 5 & Sus hijos \\
\hline & & Tolbaños de Abajo & $\mathrm{XV}$ & 45 & SSSSS & 5 & Sus hijos \\
\hline & & Huerta de Arriba & XV & 46 & SSSS & 4 & Sus hijos \\
\hline & & Riocavado de la Sierra & XV & 47 & SSSSS & 5 & Sus hijos \\
\hline & & $\begin{array}{l}\text { Quintanilla de Urrilla } \\
\text { Barbadillo de los }\end{array}$ & $\mathrm{XV}$ & 48 & SSSS & 4 & Sus hijos \\
\hline & & Herreros & $\mathrm{XV}$ & 49 & SSSSS & 5 & Sus hijos \\
\hline & & Espejón & XV & 65 & $\mathrm{~B}$ & 1 & Su viuda Urraca \\
\hline & & Espeja de San Marcelino & XV & 73 & AASSSS & 6 & Su viuda Urraca \\
\hline & & Orillares & XV & 73,1 & AASSSS & 6 & Su viuda Urraca \\
\hline & & La Lodosa & $\mathrm{XV}$ & 73,11 & AASSSS & 6 & $\begin{array}{l}\text { Su viuda } \\
\text { Urraca.Yermo }\end{array}$ \\
\hline & & Aldea de Suso & $\mathrm{XV}$ & 73,12 & AASSSS & 6 & $\begin{array}{l}\text { Su viuda } \\
\text { Urraca. Yermo }\end{array}$ \\
\hline & & Santovenia & $\mathrm{XV}$ & 73,2 & AASSSS & 6 & Su viuda Urraca \\
\hline & & Guijosa & $\mathrm{XV}$ & 73,3 & AASSSS & 6 & Su viuda Urraca \\
\hline & & La Hinojosa & $\mathrm{XV}$ & 73,4 & AASSSS & 6 & Su viuda Urraca \\
\hline & & Cabañuelas & XV & 73,5 & AASSSS & 6 & Su viuda Urraca \\
\hline & & San Asenjo & $\mathrm{XV}$ & 73,6 & AASSSS & 6 & Su viuda Urraca \\
\hline & & Ledigo & XV & 73,7 & AASSSS & 6 & $\begin{array}{l}\text { Su viuda } \\
\text { Urraca.Yermo }\end{array}$ \\
\hline & & Pisana & XV & 73,8 & AASSSS & 6 & $\begin{array}{l}\text { Su viuda } \\
\text { Urraca.Yermo }\end{array}$ \\
\hline & & Pioza & XV & 73,9 & AASSSS & 6 & $\begin{array}{l}\text { Su viuda } \\
\text { Urraca. Yermo }\end{array}$ \\
\hline \multirow[t]{7}{*}{ Pedro de Haro } & 20 & Villovela de Esgueva & $\mathrm{I}$ & 13 & $\mathrm{~S}$ & 1 & \\
\hline & & Melgar de Fernamental & $\mathrm{XI}$ & 58 & BB & 2 & \\
\hline & & Quintanilla & $\mathrm{XI}$ & 58,1 & $\mathrm{BB}$ & 2 & \\
\hline & & Requejo & XI & 58,2 & $\mathrm{BB}$ & 2 & \\
\hline & & Velilla & $\mathrm{XI}$ & 58,3 & $\mathrm{BB}$ & 2 & \\
\hline & & Olmillos de Sasamón & $\mathrm{XI}$ & 101 & $S$ & 1 & \\
\hline & & Carazo & XV & 6 & B & 1 & \\
\hline
\end{tabular}


IGNACIO ÁLVAREZ BORGE

\begin{tabular}{|c|c|c|c|c|c|c|c|}
\hline Señor & & Lugar & Mer. & $\mathrm{N}^{\mathrm{o}}$ & Tipo & Srs. & Otros \\
\hline & & Jaramillo Quemado & $X V$ & 26 & $\mathrm{~B}$ & 1 & \\
\hline & & Pinilla de los Moros & $X V$ & 27 & BBB & 3 & \\
\hline & & Tañabueyes & $X V$ & 28 & B & 1 & \\
\hline & & Pinilla Trasmonte & $X V$ & 33 & B & 1 & \\
\hline & & Vadocondes & $X V$ & 81 & B & 1 & \\
\hline & & Bahabón de Esgueva & $\mathrm{XV}$ & 98 & $S$ & 1 & \\
\hline & & Oquillas & $X V$ & 99 & $\mathrm{~S}$ & 1 & \\
\hline & & Santibáñez de Esgueva & $\mathrm{XV}$ & 100 & $S$ & 1 & \\
\hline & & Pinillos de Esgueva & $X V$ & 102 & $S$ & 1 & \\
\hline & & Terradillos de Esgueva & $X V$ & 103 & $S$ & 1 & \\
\hline & & Gumiel del Mercado & $X V$ & 105 & $\mathrm{~S}$ & 1 & \\
\hline & & Villatuelda & $\mathrm{XV}$ & 106 & $\mathrm{~S}$ & 1 & \\
\hline & & Pineda-Trasmonte & $\mathrm{XV}$ & 109 & $\mathbf{B}$ & 1 & \\
\hline \multicolumn{8}{|c|}{ Fernando Rodríguez } \\
\hline \multirow[t]{17}{*}{ de Villalobos } & 17 & Los Tremellos & $\mathrm{XI}$ & 26 & $\mathrm{BB}$ & 2 & \\
\hline & & Siero de Valdelateja & XUII & 56 & $\mathrm{AAB}$ & 3 & \\
\hline & & Pesquera de Ebro & XIII & 72 & SS & 2 & \\
\hline & & Rioseras & XIII & 78 & $\mathrm{~B}$ & 1 & \\
\hline & & Masa & XIII & 80 & ASS & 3 & \\
\hline & & San Felices & XIII & 84 & $S$ & 1 & \\
\hline & & Tubilla del Agua & XIII & 85 & AAS & 3 & \\
\hline & & S.Andrés de Montearados & XIII & 89 & $\mathrm{~s}$ & 1 & \\
\hline & & Tablada & XIII & 91 & SS & 2 & \\
\hline & & Nocedo & XIII & 93 & SS & 2 & \\
\hline & & Sedano & XIII & 94 & SSS & 3 & \\
\hline & & Covanera & XIII & 99 & AASS & 4 & \\
\hline & & Bañuelos de Rudrón & $\mathrm{XIII}$ & 101 & SSSS & 4 & \\
\hline & & Moradillo del Castillo & XIII & 104 & SS & 2 & \\
\hline & & Sta. Coloma del Rudrón & XIII & 105 & SS & 2 & \\
\hline & & Gredilla de Sedano & XUII & 109 & SS & 2 & \\
\hline & & Cortiguera & XIII & 111 & AS & 2 & 1 solar \\
\hline \multirow[t]{15}{*}{$\begin{array}{l}\text { Ruy González } \\
\text { de Castañeda }\end{array}$} & 15 & $\begin{array}{l}\text { Villafuerte de Esgueva } \\
\text { Villanueva de Gonzalo }\end{array}$ & I & 2 & ASSSS & 5 & \\
\hline & & García & I & 4 & B & 1 & \\
\hline & & Esguevillas de Esgueva & I & 29 & B & 1 & \\
\hline & & Galleta & $I$ & 35 & B & 1 & \\
\hline & & Renedo & $I$ & 40 & B & 1 & \\
\hline & & Vertabillo & $\mathrm{I}$ & 41 & B & 1 & \\
\hline & & Villaconancio & I & 42 & ASSS & 4 & \\
\hline & & Hontoria & I & 44 & $\mathrm{~S}$ & 1 & \\
\hline & & Sombrión & $\mathrm{I}$ & 45 & $\mathrm{BB}$ & 2 & \\
\hline & & Trashedo & $\mathrm{VI}$ & 56 & SS & 2 & l solar \\
\hline & & Prádanos del Tozo & $\mathrm{VI}$ & 57 & SS & 2 & 1 solar \\
\hline & & Villoba & VI & 58 & SSS & 3 & 1 solar \\
\hline & & Barrio Panizares & $\mathrm{VI}$ & 59 & SSS & 3 & 1 solar \\
\hline & & La Piedra & $\mathrm{VI}$ & 64 & SS & 2 & 2 solares \\
\hline & & Ventosilla & $\mathrm{XV}$ & 97 & SS & 2 & \\
\hline
\end{tabular}


NOBLEZA Y SEÑORÍOS EN CASTILLA LA VIEJA MERIDIONAL A MEDLADOS DEL SIGLO XIV

\begin{tabular}{|c|c|c|c|c|c|c|c|}
\hline Señor & & Lugar & Mer. & $\mathrm{N}^{\circ}$ & Tipo & Srs. & Otros \\
\hline \multirow[t]{14}{*}{ Reina } & \multirow[t]{14}{*}{14} & Espinosa de Cerrato & $\mathbf{I}$ & 17 & $\mathrm{R}$ & 1 & \\
\hline & & Tabanera de Cerrato & I & 62 & $\mathrm{R}$ & 1 & \\
\hline & & Vllahán de Palenzuela & I & 64 & $\mathrm{R}$ & 1 & \\
\hline & & Palenzuela & 1 & 67 & $\mathrm{R}$ & 1 & \\
\hline & & Henar & 1 & 67,1 & $\mathbf{R}$ & 1 & \\
\hline & & Valles de Palenzuela & I & 67,2 & $\mathrm{R}$ & 1 & \\
\hline & & Salazar de Amaya & $\mathrm{VI}$ & 79 & $\mathrm{R}$ & 1 & \\
\hline & & Villadiego & $\mathrm{VI}$ & 84 & $\mathbf{R}$ & 1 & \\
\hline & & Sotresgudo & VI & 94 & $\mathbf{R}$ & 1 & \\
\hline & & Barrialba & VI & 98 & $\mathrm{R}$ & 1 & \\
\hline & & Astudillo & $\mathrm{XI}$ & 73 & $\mathbf{R}$ & 1 & \\
\hline & & Vinienigo & $\mathrm{XI}$ & 73,1 & $\mathrm{R}$ & 1 & \\
\hline & & Santibáñez & $\mathrm{XI}$ & 73,2 & $\mathbf{R}$ & 1 & \\
\hline & & Torre cerca de Astudillo & $\mathrm{XI}$ & 74 & AAR & 3 & 22 solares \\
\hline
\end{tabular}

Alvar Rodríguez

de Aza

13

Torrepadre

Violeta

Villahoz

Talamanca

Congosto

Escuderos

Bustillo

Quintanilla de Río Franco

Castellanos

Villazopeque

Alleluengo

Torrecitores

Paules del Agua

$\begin{array}{lllll}\text { I } & 19 & \text { B } & 1 & \\ \text { I } & 19,1 & \text { B } & 1 & \text { Yermo } \\ \text { I } & 20 & \text { B } & 1 & \\ \text { I } & 20,1 & \text { B } & 1 & \text { Yermo } \\ \text { I } & 20,2 & \text { B } & 1 & \text { Yermo } \\ \text { I } & 21 & \text { B } & 1 & \\ \text { I } & 21,1 & \text { B } & 1 & \text { Despoblado } \\ \text { I } & 28 & \text { B } & 1 & \\ \text { I } & 28,1 & \text { B } & 1 & \text { Yermo } \\ \text { XIII } & 115 & \text { R } & 1 & \\ \text { XIII } & 116 & \text { R } & 1 & \\ \text { XV } & 112 & \text { B } & 1 & \\ \text { XV } & 122 & \text { B } & 1 & \end{array}$

Juana Rodríguez

de Torquemada

Hornillos de Cerrato
Espeja de San Marcelino
Orillares
La Lodosa
Aldea de Suso
Santovenia
Guijosa
La Hinojosa
Cabañuelas
San Asenjo
Ledigo
Pisana
Pioza
Tariego
Villasandino

$\begin{array}{lllll}\text { I } & 56 & \text { SSSSSSS } & 7 & \\ \text { XV } & 73 & \text { AASSSS } & 6 & \\ \text { XV } & 73,1 & \text { AASSSS } & 6 & \\ \text { XV } & 73,11 & \text { AASSSS } & 6 & \text { Yermo } \\ \text { XV } & 73,12 & \text { AASSSS } & 6 & \text { Yermo } \\ \text { XV } & 73,2 & \text { AASSSS } & 6 & \\ \text { XV } & 73,3 & \text { AASSSS } & 6 & \\ \text { XV } & 73,4 & \text { AASSSS } & 6 & \\ \text { XV } & 73,5 & \text { AASSSS } & 6 & \\ \text { XV } & 73,6 & \text { AASSSS } & 6 & \\ \text { XV } & 73,7 & \text { AASSSS } & 6 & \text { Yermo } \\ \text { XV } & 73,8 & \text { AASSSS } & 6 & \text { Yermo } \\ \text { XV } & 73,9 & \text { AASSSS } & 6 & \text { Yermo } \\ & & & & \\ \text { I } & 85 & \text { R } & 1 & \\ \text { XI } & 3 & \text { AARB } & 4 & \end{array}$




\section{IGNACIO ÁLVAREZ BORGE}

\begin{tabular}{|c|c|c|c|c|c|c|c|}
\hline Señor & & Lugar & Mer. & $N^{o}$ & Tipo & Srs. & Otros \\
\hline & & Castrojeriz & $\mathrm{XI}$ & 114 & AASR & 4 & \\
\hline & & Modubar de San Cebrián & $\mathrm{XI}-\mathrm{B}$ & 113 & $\mathrm{R}$ & 1 & \\
\hline & & Orbaneja del Castillo & XIII & 97 & $\mathrm{R}$ & 1 & \\
\hline & & Canales de la Sierra & $X V$ & 50 & $\mathrm{R}$ & 1 & \\
\hline & & Villavelayo & $\mathrm{XV}$ & 51 & $\mathrm{R}$ & 1 & \\
\hline & & Monterrubio de la Demanda & $\mathrm{XV}$ & 52 & $\mathrm{R}$ & 1 & \\
\hline & & Viniegra de Abajo & XV & 53 & $\mathbf{R}$ & 1 & \\
\hline & & Ventrosa & XV & 54 & $\mathrm{R}$ & 1 & \\
\hline & & Mansilla & $\mathrm{XV}$ & 55 & $\mathbf{R}$ & 1 & \\
\hline & & Brieva de Cameros & $X V$ & 56 & $\mathbf{R}$ & 1 & \\
\hline & & Montenegro de Cameros & XV & 57 & $\mathbf{R}$ & 1 & \\
\hline \multicolumn{8}{|c|}{ Lope Rodriguez } \\
\hline \multirow[t]{14}{*}{ de Villalobos } & 12 & Ornejo & I & 63 & B & 1 & \\
\hline & & Palazuelos de Muñó & $\mathrm{XI}$ & 17 & $\mathrm{~B}$ & 1 & \\
\hline & & Santa María Tajadura & $\mathrm{XI}$ & 22 & B & 1 & \\
\hline & & Pedrosa de Río Urbel & $\mathrm{XI}$ & 32 & B & 1 & \\
\hline & & Quintanayuz & $\mathrm{XI}$ & 33 & B & 1 & \\
\hline & & Villanueva de & & & & & \\
\hline & & las Carretas & $\mathrm{XII}$ & 7 & B & 1 & \\
\hline & & Celada del Camino & XII & 14 & B & 1 & \\
\hline & & Villamayor de & & & & & \\
\hline & & los Montes & XII & 24 & B & 1 & \\
\hline & & Iglesias & XII & 41 & $S$ & 1 & \\
\hline & & Nidáguila & XIII & 74 & $\mathrm{~B}$ & 1 & \\
\hline & & Valdeajos & XIII & 95 & $\mathrm{~S}$ & 1 & \\
\hline & & Escalada & XIII & 100 & SSS & 3 & \\
\hline \multicolumn{8}{|c|}{ Ruy Fernández } \\
\hline \multirow[t]{12}{*}{ de Tobar } & 12 & Valle de Cerrato & $I$ & 39 & $\mathrm{~B}$ & 1 & \\
\hline & & Sordillos & $\mathrm{VI}$ & 49 & $\mathrm{BB}$ & 2 & Sus hijos \\
\hline & & Tapia & VI & 25 & $\mathrm{~B}$ & 1 & Sus hijos \\
\hline & & Villamar & $\mathrm{VI}$ & 27 & B & 1 & Sus hijos \\
\hline & & Guadilla de Villamar & $\mathrm{VI}$ & 28 & B & 1 & Sus hijos \\
\hline & & Castromorca & VI & 30 & $\mathbf{B}$ & 1 & Sus hijos \\
\hline & & Villalibado & VI & 32 & B & 1 & Sus hijos \\
\hline & & Villahizán de Treviño & VI & 50 & $\mathbf{B}$ & 1 & Sus hijos \\
\hline & & Manciles & $\mathrm{XI}$ & 34 & $\mathrm{BB}$ & 2 & Sus hijos \\
\hline & & Susinos del Páramo & $\mathrm{XI}$ & 48 & $\mathbf{B}$ & 1 & Sus hijos \\
\hline & & Tobar & $\mathrm{XI}$ & 50 & B & 1 & Sus hijos \\
\hline & & Quintanaseca & $\mathrm{XI}$ & 63 & $\mathrm{~B}$ & 1 & Sus hijos \\
\hline \multicolumn{8}{|l|}{ Diego Pérez } \\
\hline \multirow[t]{3}{*}{ Sarmiento } & 11 & Villamiel de la Sierra & XI-B & 94 & ASSSS & 5 & $\begin{array}{l}\text { Su mujer María } \\
\text { de Velasco }\end{array}$ \\
\hline & & Vallejimeno & $\mathrm{XV}$ & 40 & SS & 2 & Por su mujer \\
\hline & & Tolbaños de Arriba & $\mathrm{XV}$ & 43 & SSSS & 4 & $\begin{array}{l}\text { Su mujer María } \\
\text { de Velasco }\end{array}$ \\
\hline
\end{tabular}


NOBLEZA Y SEÑORÍOS EN CASTILLA LA VIEJA MERIDIONAL A MEDIADOS DEL SIGLO XIV

\begin{tabular}{|c|c|c|c|c|c|c|}
\hline Señor & Lugar & Mer. & $\mathrm{N}^{\circ}$ & Tipo & Srs. & Otros \\
\hline & Huerta de Abajo & $\mathrm{XV}$ & 44 & SSSSS & 5 & $\begin{array}{l}\text { Su mujer María } \\
\text { de Velasco }\end{array}$ \\
\hline & Tolbaños de Abajo & $\mathrm{XV}$ & 45 & SSSSS & 5 & $\begin{array}{l}\text { Su mujer María } \\
\text { de Velasco }\end{array}$ \\
\hline & Huerta de Arriba & $X V$ & 46 & SSSS & 4 & $\begin{array}{l}\text { Su mujer María } \\
\text { de Velasco }\end{array}$ \\
\hline & Riocavado de la Sierra & $X V$ & 47 & SSSSS & 5 & $\begin{array}{l}\text { Su mujer Maria } \\
\text { de Velasco }\end{array}$ \\
\hline & Quintanilla de Urrilla & $X V$ & 48 & SSSS & 4 & $\begin{array}{l}\text { Su mujer Maria } \\
\text { de Velasco }\end{array}$ \\
\hline & Barbadillo de los Herreros & $X V$ & 49 & SSSSS & 5 & $\begin{array}{l}\text { Su mujer María } \\
\text { de Velasco }\end{array}$ \\
\hline & Hornillos & $X V$ & 63 & SS & 2 & Por su mujer \\
\hline & Palacios de la Sierra & $X V$ & 71 & SSS & 3 & $\begin{array}{l}\text { Su mujer María } \\
\text { de Velasco }\end{array}$ \\
\hline
\end{tabular}

Ramir Flórez

de Guzmán

9

\section{Guzmán}

Contreras

Ciruelos de Cervera

$\begin{array}{llll}\text { I } & 11 & \text { B } & 1\end{array}$

XV 4 ASSSS 5

Zayas de Torre

XV 8 ASS 3

Arauzo de Salce

XV 77 ASSS 4

Arauzo de Miel

$\begin{array}{lll}X V & 79 & \text { BBB }\end{array}$

Arauzo de Torre

$\begin{array}{llll}X V & 86 & B & 1\end{array}$

Alcubilla de Avellaneda

$\begin{array}{llll}\text { XV } & 87 & \text { B } & 1\end{array}$

Hontoria de Valdearados

XV $90 \quad \mathrm{~S}$

XV $110 \quad B$

\section{Concejo}

de Burgos

Santa María de Muñó
Villavieja de Muñó
Pelilla
Villaverde del Monte
Mazuela de Muñó
Quintanilla-Somuñó
Arroyo de Muñó
Pampliega

$\begin{array}{llll}\text { XII } & 67 & \text { R } & 1 \\ \text { XII } & 67,1 & \text { R } & 1 \\ \text { XII } & 67,2 & \text { R } & 1 \\ \text { XII } & 67,3 & \text { R } & 1 \\ \text { XII } & 68 & \text { R } & 1 \\ \text { XII } & 71 & \text { R } & 1 \\ \text { XII } & 72 & \text { R } & 1 \\ \text { XII } & 73 & \text { R } & 1\end{array}$

Diego García de Padilla

$\begin{array}{ll}7 & \text { Villaverde Mogina } \\ \text { Moral } \\ \text { Cordovilla La Real } \\ \text { Villamedianilla } \\ \text { Quintana cerca Los Balbases } \\ \text { Vallegera } \\ \text { Villimar }\end{array}$

$\begin{array}{llll}\text { I } & 68 & \text { ABB } & 3 \\ \text { I } & 69 & \text { SS } & 2 \\ \text { XI } & 19 & \text { B } & 1 \\ \text { XI } & 20 & \text { B } & 1 \\ \text { XI } & 78 & \text { S } & 1 \\ \text { XI } & 79 & \text { SSS } & 3 \\ \text { XI } & 82 & \text { SSS } & 3\end{array}$

9 solares 


\begin{tabular}{|c|c|c|c|c|c|c|c|}
\hline Señor & & Lugar & Mer. & $\mathbf{N}^{0}$ & Tipo & Srs. & Otros \\
\hline \multicolumn{8}{|c|}{ Gutierre Fernández } \\
\hline \multirow[t]{7}{*}{ Delgadillo } & 7 & Coculina & VI & 20 & B & 1 & \\
\hline & & Quintanilla & VI & 21 & B & 1 & \\
\hline & & Bustillo del Páramo & $\mathrm{VI}$ & 24 & $\mathrm{~B}$ & 1 & \\
\hline & & Fuencivil & $\mathrm{VI}$ & 44 & B & 1 & \\
\hline & & Villoba & VI & 58 & SSS & 3 & \\
\hline & & Arcellares & VI & 62 & SS & 2 & $\begin{array}{l}\text { La mitad } \\
\text { del lugar }\end{array}$ \\
\hline & & Cernégula & XIII & 83 & AS & 2 & \\
\hline \multicolumn{8}{|l|}{ Juan Díaz } \\
\hline \multirow[t]{8}{*}{ de Rocaful } & 7 & Villanueva de Carazo & $X V$ & 7 & SS & 2 & \\
\hline & & Espinosa de Cervera & $X V$ & 20 & AAASS & 5 & \\
\hline & & Castrovido & XV & 24 & SS & 2 & \\
\hline & & Terrazas & XV & 39 & SS & 2 & \\
\hline & & Vilviestre del Pinar & $X V$ & 72 & SS & 2 & \\
\hline & & Bohigas de Perales & XV & 92 & SS & 2 & \\
\hline & & Santa María de & & & & & \\
\hline & & Añuéquez & XV & 120 & BB & 2 & \\
\hline \multicolumn{8}{|l|}{ Diego López } \\
\hline \multirow[t]{7}{*}{ de Haro } & 6 & Villanueva de Carazo & $X V$ & 7 & SS & 2 & Su viuda Sancha \\
\hline & & Castrovido & $\mathrm{XV}$ & 24 & SS & 2 & Su viuda Sancha \\
\hline & & Terrazas & $X V$ & 39 & SS & 2 & Su viuda Sancha \\
\hline & & Vilviestre del Pinar & $X V$ & 72 & SS & 2 & Su viuda Sancha \\
\hline & & Bohigas de Perales & $\mathrm{XV}$ & 92 & SS & 2 & Su viuda Sancha \\
\hline & & Santa María de & & & & & \\
\hline & & Añuéquez & XV & 120 & BB & 2 & Su viuda Sancha \\
\hline \multicolumn{8}{|l|}{ Juan Sánchez } \\
\hline \multirow[t]{7}{*}{ de Velasco } & 6 & Tolbaños de Arriba & XV & 43 & SSSS & 4 & \\
\hline & & Huerta de Abajo & $\mathrm{XV}$ & 44 & SSSSS & 5 & \\
\hline & & Tolbaños de Abajo & $X V$ & 45 & SSSSS & 5 & \\
\hline & & Riocavado de la Sierra & $X V$ & 47 & SSSSS & 5 & \\
\hline & & Quintanilla de Urrilla & $\mathrm{XV}$ & 48 & SSSS & 4 & \\
\hline & & Barbadillo de & & & & & \\
\hline & & los Herretos & $X V$ & 49 & SSSSS & 5 & \\
\hline \multicolumn{8}{|l|}{ Martín Gil de } \\
\hline \multirow[t]{6}{*}{ Alburquerque } & 6 & Villasilos & XI & 1 & B & 1 & \\
\hline & & Melgar de Fernamental & XI & 58 & BB & 2 & 15 ó 20 solares \\
\hline & & Requejo & XI & 58 & BB & 2 & \\
\hline & & Velilla & XI & 58 & $\mathrm{BB}$ & 2 & \\
\hline & & Quintanilla & XI & 58,1 & BB & 2 & \\
\hline & & Sta. María del Campo & XII & 25 & B & 1 & \\
\hline \multicolumn{8}{|l|}{ Alvar Díaz de } \\
\hline \multirow[t]{2}{*}{ Sandoval } & 5 & Sandoval de la Reina & VI & 31 & $\mathrm{BB}$ & 2 & Sus hijos \\
\hline & & Melgosa de Villadiego & VI & 34 & B & 1 & Sus hijos \\
\hline
\end{tabular}




\begin{tabular}{|c|c|c|c|c|c|c|c|}
\hline Señor & & Lugar & Mer. & $\mathbf{N}^{0}$ & Tipo & Srs. & Otros \\
\hline & & Brulles & VI & 43 & $\mathrm{BB}$ & 2 & Sus hijos \\
\hline & & Barrio Panizares & $\mathrm{VI}$ & 59 & SSS & 3 & Sus hijos, 3 solares \\
\hline & & Valtierra de Río Pisuerga & $\mathrm{XI}$ & 56 & $\mathrm{~B}$ & 1 & Sus hijos \\
\hline \multicolumn{8}{|l|}{ Garcí González } \\
\hline \multirow[t]{5}{*}{ de Villaute } & 5 & Sedano & XIII & 94 & SSS & 3 & \\
\hline & & Bañuelos de Rudrón & XIII & 101 & SSSS & 4 & \\
\hline & & Mazuelos & XIII & 106 & AS & 2 & \\
\hline & & Valdepuente & XIII & 107 & $\mathrm{~S}$ & 1 & \\
\hline & & Gredilla de Sedano & XIII & 109 & SS & 2 & \\
\hline \multicolumn{8}{|c|}{ Gómez Gutiérrez } \\
\hline \multirow[t]{5}{*}{ de Grijalba } & 5 & Mahallos & VI & 83 & BBS & 3 & \\
\hline & & Puentes de Amaya & $\mathrm{VI}$ & 95 & ASSS & 4 & \\
\hline & & Citores del Páramo & $\mathrm{XI}$ & 46 & $\mathrm{BB}$ & 2 & \\
\hline & & Perex & XI & 47 & $\mathrm{BB}$ & 2 & \\
\hline & & Arauzo de Salce & $\mathrm{XV}$ & 79 & $\mathrm{BBB}$ & 3 & \\
\hline \multicolumn{8}{|l|}{ Juan Fernández } \\
\hline \multirow[t]{5}{*}{ de Hinestrosa } & 5 & Pedrosa del Príncipe & XI & 2 & $\mathrm{BB}$ & 2 & \\
\hline & & Villalaco & $\mathrm{XI}$ & 12 & $\mathrm{~B}$ & 1 & \\
\hline & & Melgar de Yuso & $\mathrm{XI}$ & 14 & $\mathrm{~B}$ & 1 & \\
\hline & & Hinestrosa & $\mathrm{XI}$ & 70 & SSS & 3 & \\
\hline & & Villímar & $\mathrm{XI}$ & 82 & SSS & 3 & 6 solares \\
\hline \multicolumn{8}{|c|}{ Ochoa Martínez } \\
\hline \multirow[t]{5}{*}{ de Avellaneda } & 5 & Tejada & $\mathrm{XV}$ & 15 & SSS & 3 & Sus hijos \\
\hline & & Fuentearmejil & $\mathrm{XV}$ & 75 & ASSS & 4 & Sus hijos \\
\hline & & Ribalba & $X V$ & 75,1 & ASSS & 4 & Sus hijos \\
\hline & & Santervás & $\mathrm{XV}$ & 75,2 & ASSS & 4 & Sus hijos \\
\hline & & Zayuelas & XV & 75,3 & ASSS & 4 & Sus hijos \\
\hline \multicolumn{8}{|l|}{ Pedro García } \\
\hline \multirow[t]{5}{*}{ de Grijalba } & 5 & Sordillos & $\mathrm{VI}$ & 49 & $\mathrm{BB}$ & 2 & \\
\hline & & Mahallos & VI & 83 & BBS & 3 & \\
\hline & & Puentes de Amaya & $\mathrm{VI}$ & 95 & ASSS & 4 & \\
\hline & & Citores del Páramo & XI & 46 & $\mathrm{BB}$ & 2 & \\
\hline & & Perex & XI & 47 & $\mathrm{BB}$ & 2 & \\
\hline \multicolumn{8}{|l|}{ Rodrigo Pérez } \\
\hline \multirow[t]{5}{*}{ de Villalobos } & 5 & Vilviestre de Muñó & XII & 8 & BS & 3 & Sus hijos \\
\hline & & Masa & XIII & 80 & ASS & 3 & Sus hijos \\
\hline & & Tablada & XIII & 91 & SS & 2 & Sus hijos \\
\hline & & Covanera & XIII & 99 & AASS & 4 & Sus hijos \\
\hline & & Bañuelos de Rudrón & XIII & 101 & SSSS & 4 & Sus hijos \\
\hline \multicolumn{8}{|c|}{ Fernando Rodríguez } \\
\hline \multirow[t]{5}{*}{ de Villalobos } & 4 & Nocedo & XIII & 93 & SS & 2 & Su viuda Inés \\
\hline & & Sedano & XIII & 94 & SSS & 3 & Su viuda Inés \\
\hline & & Moradillo del Castillo & XIII & 104 & SS & 2 & Su viuda Inés \\
\hline & & Santa Coloma & & & & & \\
\hline & & del Rudrón & XIII & 105 & SS & 2 & Su viuda Inés \\
\hline
\end{tabular}


IGNACIO ÁLVAREZ BORGE

\begin{tabular}{|c|c|c|c|c|c|c|c|}
\hline Señor & & Lugar & Mer. & $\mathrm{N}^{\mathrm{o}}$ & Tipo & Srs. & Otros \\
\hline \multicolumn{8}{|l|}{ Gonzalo Ibáñez } \\
\hline \multirow{4}{*}{ de Amaya } & 4 & Fuentearmejil & $\mathrm{XV}$ & 75 & ASSS & 4 & \\
\hline & & Ribalba & XV & 75,1 & ASSS & 4 & \\
\hline & & Santervás & $\mathrm{XV}$ & 75,2 & ASSS & 4 & \\
\hline & & Zayuelas & $\mathrm{XV}$ & 75,3 & ASSS & 4 & \\
\hline \multicolumn{8}{|l|}{ Juan Alfonso } \\
\hline \multirow[t]{4}{*}{ Carrillo } & 4 & Arenillas de Muñó & XII & 18 & $\mathrm{~B}$ & 1 & \\
\hline & & Mazuelo de Muñó & XII & 26 & $\mathrm{~B}$ & 1 & \\
\hline & & Tornadijo & XII & 30 & B & 1 & \\
\hline & & Viniegra de Arriba & $X V$ & 58 & $\mathrm{~B}$ & 1 & \\
\hline \multicolumn{8}{|l|}{ Juan Estébanez } \\
\hline \multirow[t]{4}{*}{ de Castellanos } & 4 & Cueva de Juarros & $\mathrm{XI}-\mathrm{B}$ & 88 & ASS & 3 & \\
\hline & & Espinosa de Juarros & $\mathrm{XI}-\mathrm{B}$ & 90 & AS & 2 & \\
\hline & & Ibeas de Juarros & XI-B & 95 & AS & 2 & \\
\hline & & Belbimbre & XIII & 114 & $\mathbf{R}$ & 1 & \\
\hline \multicolumn{8}{|l|}{ Pedro Ruiz } \\
\hline \multirow[t]{4}{*}{ de Villegas } & 4 & Pedrosa del Páramo & XI & 25 & BBBBBB & 6 & \\
\hline & & Manciles & XI & 34 & $\mathrm{BB}$ & 2 & \\
\hline & & Villegas & $\mathrm{XI}$ & 43 & ВBВBB & 5 & \\
\hline & & Valdegómez & XIII & 88 & SS & 2 & \\
\hline \multicolumn{8}{|l|}{ Ruy Gutiérrez } \\
\hline \multirow{3}{*}{ de Quijada } & & San Andrés de Nava & VI & 78 & SS & 2 & Sus hijos \\
\hline & & Sta. María de Añanúñez & VI & 96 & SS & 2 & \\
\hline & & Villaveta & XI & 69 & SS & 2 & Sus hijas \\
\hline \multicolumn{8}{|l|}{ Sancho Martínez } \\
\hline \multirow[t]{4}{*}{ de Leiva } & 4 & Villamiel de la Sierra & $\mathrm{XI}-\mathrm{B}$ & 94 & ASSSS & 5 & Su mujer \\
\hline & & Zayas de Torre & XV & 77 & ASSS & 4 & \\
\hline & & Alcoba del Camino & XV & 94 & SSS & 3 & \\
\hline & & Quintanarraya & $\mathrm{XV}$ & 95 & $\mathrm{~B}$ & 1 & \\
\hline \multicolumn{8}{|c|}{ Fernando Sánchez } \\
\hline \multirow[t]{3}{*}{ de Tobar } & 3 & Avellanosa del Páramo & $\mathrm{XI}$ & 18 & B & 1 & \\
\hline & & Zumel & $\mathrm{XI}$ & 35 & $\mathrm{BB}$ & 2 & \\
\hline & & Lantadilla & $\mathrm{XI}$ & 64 & B & 1 & \\
\hline \multicolumn{8}{|l|}{ Garcí Fernández } \\
\hline \multirow[t]{3}{*}{ de Villagutiérre } & 3 & Villagutiérrez & XII & 10 & $\mathrm{AB}$ & 2 & Sus hijos \\
\hline & & Bustillos & XII & 54 & $\mathrm{~S}$ & 1 & Sus hijos \\
\hline & & Hormaza & XII & 55 & SSSS & 4 & Sus hijos \\
\hline \multicolumn{8}{|c|}{ Gonzalo González } \\
\hline \multirow[t]{3}{*}{ de Lucio } & 3 & Solanas de Valdelucio & $\mathrm{VI}$ & 1 & $\mathrm{~B}$ & 1 & \\
\hline & & Pedrosa del Páramo & $\mathrm{XI}$ & 25 & BBBBBB & 6 & \\
\hline & & Hinestrosa & XI & 70 & SSS & 3 & \\
\hline \multicolumn{8}{|l|}{ Juan Martínez } \\
\hline \multirow[t]{3}{*}{ de Rojas } & 3 & Melgosa & XIII & 76 & B & 1 & \\
\hline & & Rahedo & XIII & 77 & $\mathrm{~B}$ & 1 & \\
\hline & & Temiño & XIII & 81 & B & 1 & \\
\hline
\end{tabular}




\begin{tabular}{|c|c|c|c|c|c|c|c|}
\hline Señor & & Lugar & Mer. & $\mathrm{N}^{\mathrm{o}}$ & Tipo & Srs. & Otros \\
\hline \multicolumn{8}{|l|}{ Juan Rodríguez } \\
\hline \multirow[t]{3}{*}{ de Villegas } & 3 & Olmos de la Picaza & VI & 29 & $\mathrm{BBB}$ & 3 & \\
\hline & & Pedrosa del Páramo & $\mathrm{XI}$ & 25 & ВBBBBB & 86 & \\
\hline & & Hinestrosa & $\mathrm{XI}$ & 70 & SSS & 3 & \\
\hline \multicolumn{8}{|l|}{ Sancho Ruiz } \\
\hline \multirow[t]{3}{*}{ de Rojas } & 3 & Villafuerte de Esgueva & I & 2 & ASSSS & 5 & \\
\hline & & Hornillos de Cerrato & I & 56 & SSSSSSS & 7 & \\
\hline & & Cabia & XII & 29 & B & 1 & \\
\hline \multicolumn{8}{|l|}{ Alfonso Díaz } \\
\hline \multirow[t]{2}{*}{ de Baltanás } & 2 & Canillas de Esgueva & I & 8 & SSSSS & 5 & \\
\hline & & Encinas de Esgueva & I & 9 & ssss & 4 & \\
\hline \multicolumn{8}{|c|}{ Alfonso Fernández } \\
\hline \multirow{3}{*}{ de Huidobro } & 2 & Villaescusa del Butrón & XIII & 60 & AS & 2 & Su nieto \\
\hline & & & & & & & Alfonso \\
\hline & & Huidobro & XIII & 73 & $\mathrm{~S}$ & 1 & \\
\hline \multicolumn{8}{|l|}{ Fernán Sánchez } \\
\hline \multirow[t]{2}{*}{ de Valladolid } & 2 & Cubillas de Cerrato & $I$ & 31 & $s$ & 1 & \\
\hline & & Grijalba & $\mathrm{I}$ & 32 & $S$ & 1 & Yermo \\
\hline \multicolumn{8}{|l|}{ Fernando Ruiz } \\
\hline \multirow[t]{2}{*}{ de Villalobos } & 2 & Hormazuela & $\mathrm{VI}$ & 22 & B & 1 & \\
\hline & & Tobes & XIII & 66 & $B$ & 1 & \\
\hline \multicolumn{8}{|l|}{ Garcí Laso } \\
\hline \multirow[t]{2}{*}{ de la Vega } & 2 & Hornillos de Cerrato & I & 56 & SSSSSSS & 7 & Su hijo \\
\hline & & Puentes de Amaya & $\mathrm{VI}$ & 95 & ASSS & 4 & 1 solar \\
\hline \multicolumn{8}{|l|}{ Gonzalo Ramírez } \\
\hline \multirow[t]{2}{*}{ de Mazuela } & 2 & Hormaza & XII & 55 & SSSS & 4 & \\
\hline & & Ciruelos de Cervera & $X V$ & 8 & ASS & 3 & \\
\hline \multicolumn{8}{|l|}{ Juan Alfonso } \\
\hline \multirow[t]{2}{*}{ de Zumel } & 2 & Pinilla de los Moros & $X V$ & 27 & $\mathrm{BBB}$ & 3 & \\
\hline & & Rupelo & $\mathrm{XV}$ & 31 & BS & 2 & \\
\hline \multirow[t]{2}{*}{ Juan de la Peña } & 2 & Castrillo de Onielo & $I$ & 43 & $\mathrm{BBB}$ & 3 & \\
\hline & & Olmos de la Picaza & VI & 29 & $\mathrm{BBB}$ & 3 & \\
\hline \multicolumn{8}{|l|}{ Juan Fernández } \\
\hline \multirow[t]{2}{*}{ de Grijalba } & 2 & Mahallos & $\mathrm{VI}$ & 83 & BBS & 3 & 1 solar \\
\hline & & Cañizar de los Ajos & XI & 27 & $\mathrm{BB}$ & 2 & \\
\hline \multicolumn{8}{|l|}{ Juan García } \\
\hline \multirow[t]{2}{*}{ Manrique } & 2 & Torremoronta & I & 27 & $S$ & 1 & \\
\hline & & Quintanilla Morocisla & XIII & 1 & $B$ & 1 & \\
\hline Juan Martínez & & & & & & & \\
\hline de Avellaneda & 2 & Hacinas & $X V$ & 16 & ASS & 3 & Sus hijos \\
\hline & & Zayas de Torre & $X V$ & 77 & ASSS & 4 & Sus hijos \\
\hline Juan Rodríguez & & & & & & & \\
\hline de Sasamón & 2 & Calabanzos & I & 83 & $\mathrm{~S}$ & 1 & \\
\hline & & Baños de Cerrato & I & 84 & $\mathrm{R}$ & 1 & \\
\hline
\end{tabular}




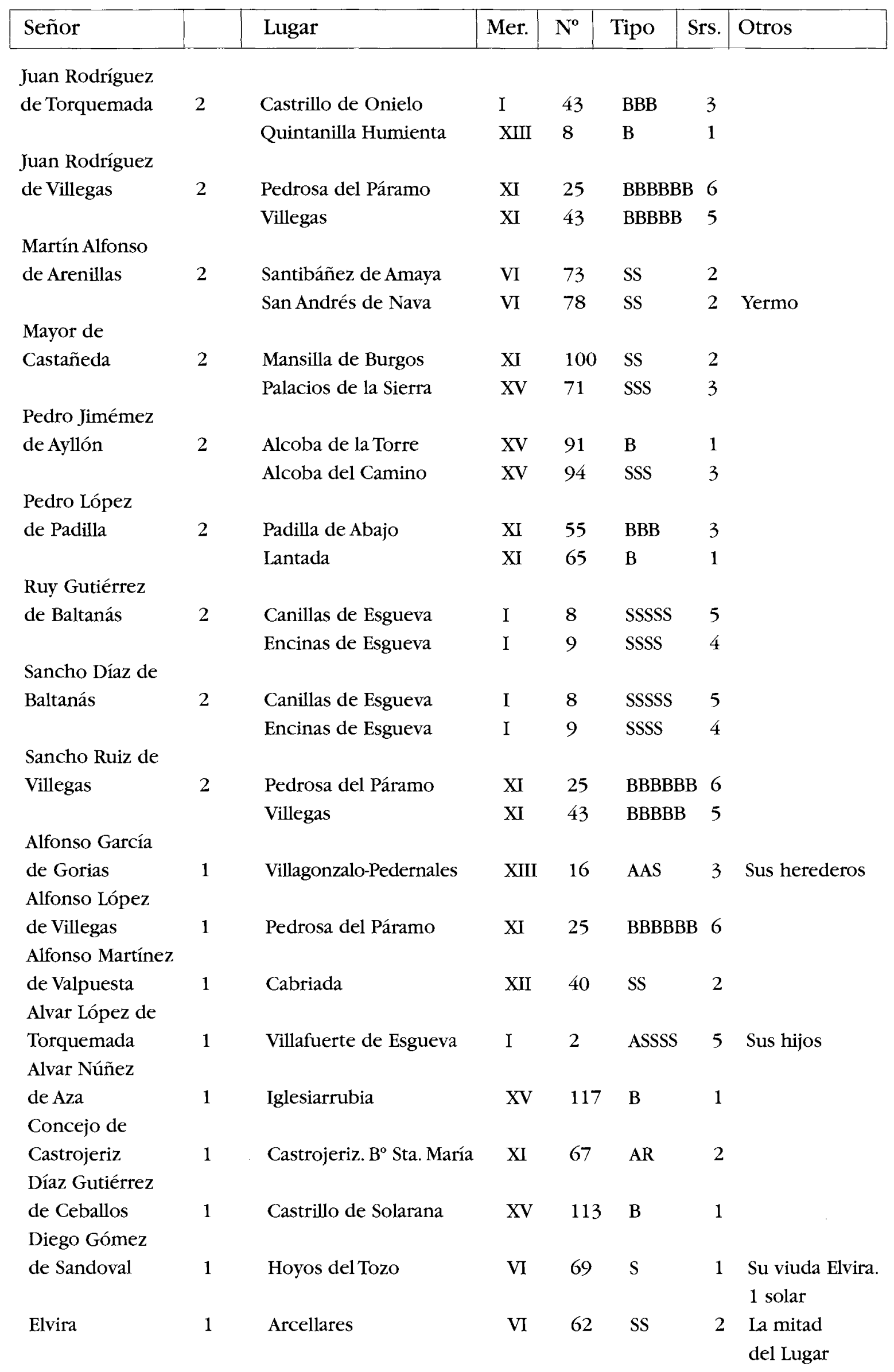




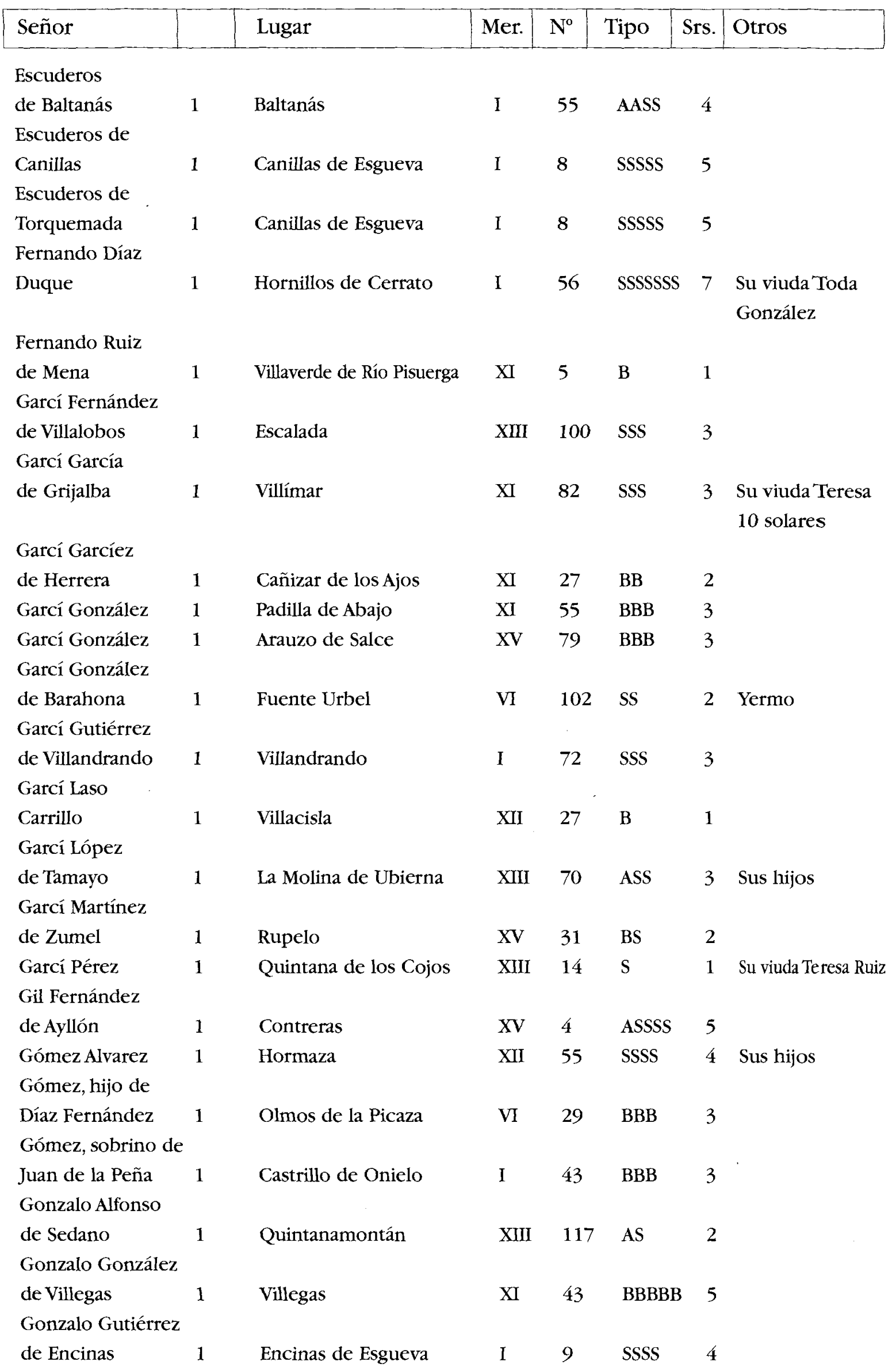




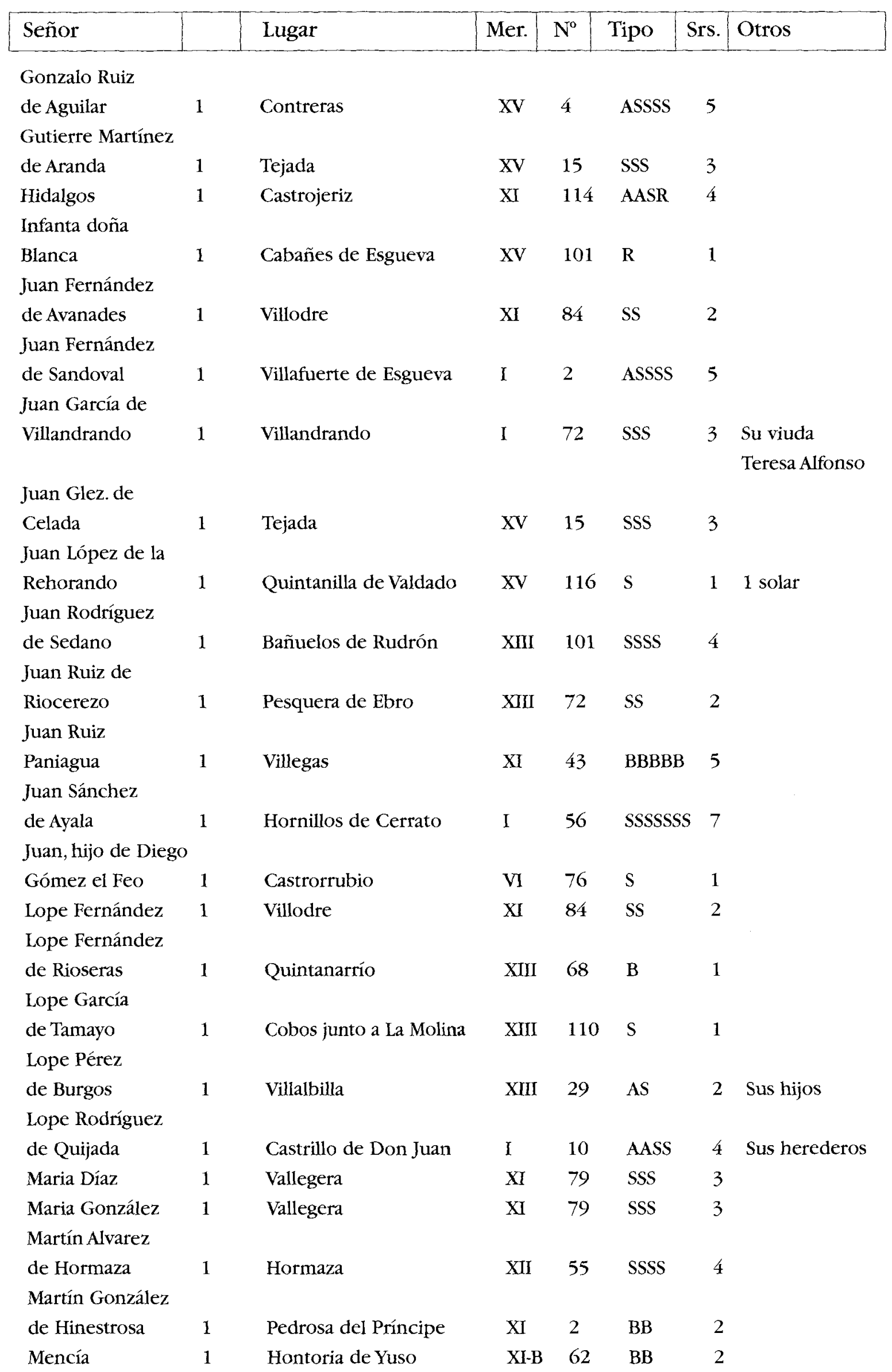


NOBLEZA Y SEÑORÍOS EN CASTILLA LA VIEJA MERIDIONAL A MEDIADOS DEL SIGLO XIV

\begin{tabular}{|c|c|c|c|c|c|c|c|}
\hline Señor & & Lugar & Mer. & $\mathbf{N}^{\circ}$ & Tipo & Srs. & Otros \\
\hline $\begin{array}{l}\text { Muño González } \\
\text { de Herrera }\end{array}$ & 1 & Alba de Cerrato & I & 37 & B & 1 & \\
\hline $\begin{array}{l}\text { Pedro Bravo } \\
\text { de Zumel } \\
\text { Pedro Fernández }\end{array}$ & 1 & Valdegómez & XIII & 88 & SS & 2 & \\
\hline Cabeza de Vaca & 1 & Cabriada & XII & 40 & SS & 2 & $\begin{array}{l}\text { Su viuda } \\
\text { Juana Pérez }\end{array}$ \\
\hline $\begin{array}{l}\text { Pedro Fernández } \\
\text { el Niño }\end{array}$ & 1 & Montuenga & XII & 11 & B & 1 & \\
\hline $\begin{array}{l}\text { Pedro Suárez } \\
\text { de Toledo }\end{array}$ & 1 & Albillos & XIII & 15 & $\mathrm{~B}$ & 1 & \\
\hline $\begin{array}{l}\text { Rodrigo Rodríguez } \\
\text { de Torquemada }\end{array}$ & 1 & Sombrión & I & 45 & $\mathrm{BB}$ & 2 & \\
\hline $\begin{array}{l}\text { Ruy Díaz Cabeza } \\
\text { de Vaca }\end{array}$ & 1 & Hontoria de Cerrato & I & 87 & S & 1 & \\
\hline $\begin{array}{l}\text { Ruy González de } \\
\text { Villayerno }\end{array}$ & 1 & Castrillo del Val & XIII & 12 & AAAS & 4 & \\
\hline Sancho Manuel & 1 & Villaconancio & I & 42 & ASSS & 4 & Sus hijos \\
\hline $\begin{array}{l}\text { Sancho Pérez } \\
\text { de Contreras }\end{array}$ & 1 & Contreras & $X V$ & 4 & ASSSS & 5 & \\
\hline $\begin{array}{l}\text { Sancho Ruiz } \\
\text { de Zayas }\end{array}$ & 1 & Zayas de Bascones & $\mathrm{XV}$ & 78 & $\mathrm{~S}$ & 1 & \\
\hline $\begin{array}{l}\text { Sancho Sánchez } \\
\text { de Rojas }\end{array}$ & 1 & Villalonquejar & XIII & 4 & S & 1 & \\
\hline $\begin{array}{l}\text { Tello Alvarez de Q } \\
\text { de los Caballeros }\end{array}$ & 1 & Espinosa de Cervera & XV & 20 & AAASS & 5 & \\
\hline
\end{tabular}


